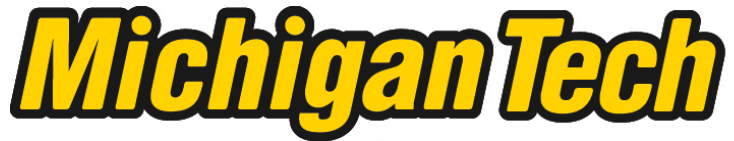 \\ Michigan Technological University Create the Future Digital Commons @ Michigan Tech
}

\section{VOLUME YIELDS OF SMALLHOLDER Eucalyptus grandis W. HILL EX MAIDEN STANDS IN EASTERN PARAGUAY}

Brook F. Alloway

Michigan Technological University

Follow this and additional works at: https://digitalcommons.mtu.edu/etds

Part of the Forest Sciences Commons, and the Natural Resources Management and Policy Commons Copyright 2014 Brook F. Alloway

\section{Recommended Citation}

Alloway, Brook F., "VOLUME YIELDS OF SMALLHOLDER Eucalyptus grandis W. HILL EX MAIDEN STANDS IN EASTERN PARAGUAY", Master's Thesis, Michigan Technological University, 2014.

https://doi.org/10.37099/mtu.dc.etds/765

Follow this and additional works at: https://digitalcommons.mtu.edu/etds

Part of the Forest Sciences Commons, and the Natural Resources Management and Policy Commons 
VOLUME YIELDS OF SMALLHOLDER Eucalyptus grandis W. HILL EX MAIDEN STANDS IN EASTERN PARAGUAY

By

Brook Alloway

\begin{abstract}
A THESIS
Submitted in partial fulfillment of the requirements for the degree of MASTER OF SCIENCE

In Forestry
\end{abstract}

MICHIGAN TECHNOLOGICAL UNIVERSITY

2014

Copyright 2014 Brook Alloway 
This thesis has been approved in partial fulfillment of the requirements for the degree of MASTER OF SCIENCE in Forestry.

School of Forest Resources and Environmental Science

\author{
Thesis Advisor: $\quad$ Blair D. Orr \\ Committee Member: Linda M. Nagel \\ Committee Member: Carol A. MacLennan \\ School Dean: $\quad$ Terry L. Sharik
}


To my father 


\section{Table of Contents}

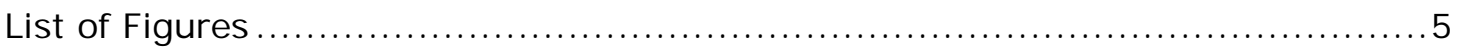

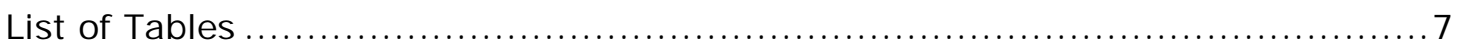

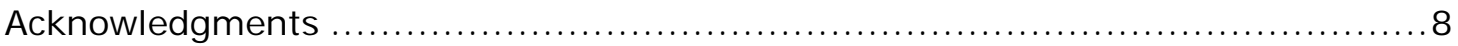

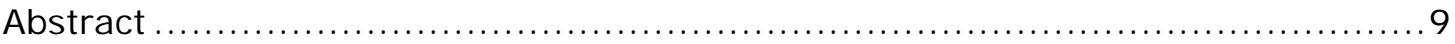

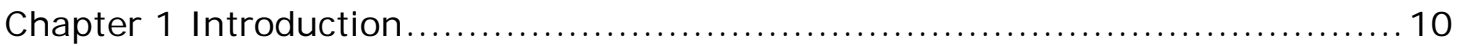

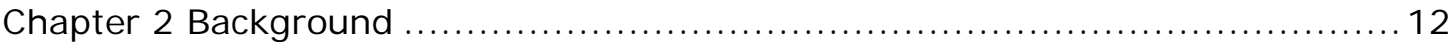

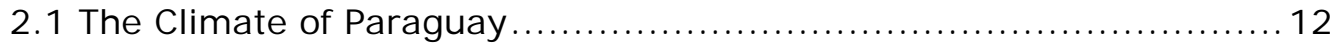

2.2 The History and Economy of Paraguay............................. 13

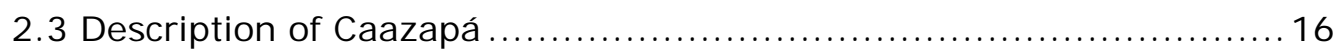

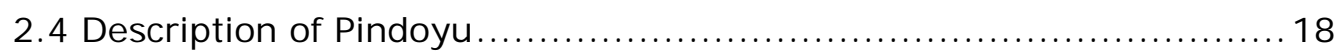

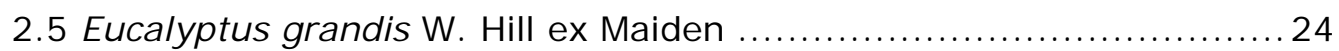

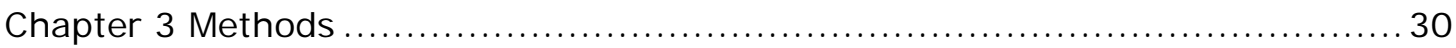

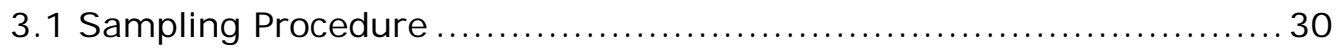

3.2 Stand Characteristics and Silvicultural Practices.................... 32

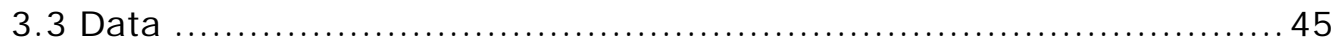

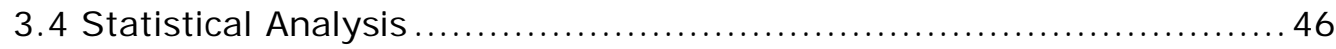

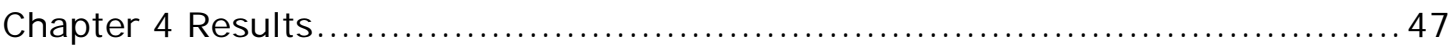

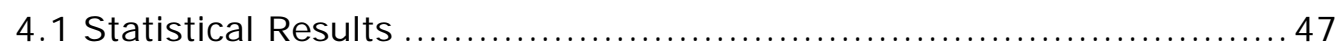

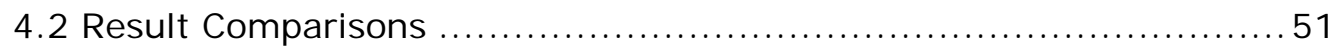

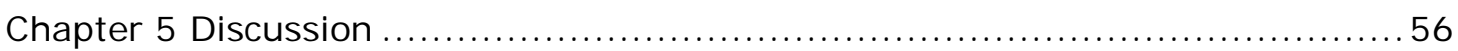

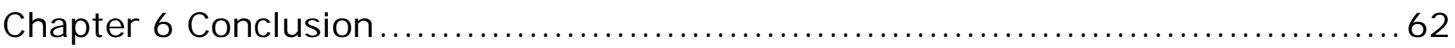

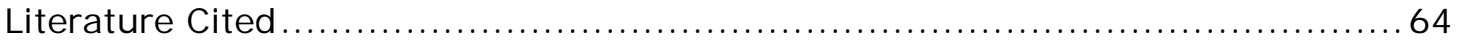

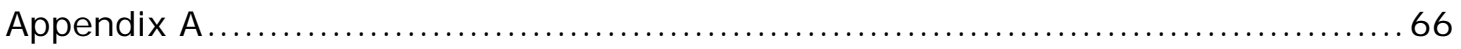

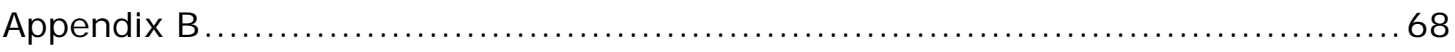




\section{List of Figures}

Figure 2.1 Paraguay's location in South America. .............................. 12

Figure 2.2 Paraguay, the Department of Caazapá, and the settlement of Pindoyu.

Figure 2.3 A typical smallholder family in Pindoyu, Caazapá.

Figure 2.4 Smallholders heading to their farm fields to till soil with oxen.....

Figure 2.5 Smallholdings in Pindoyu include E. grandis, pasture land, and family compounds.

Figure 2.6 Committee Santa Cecilia meeting with Peace Corps Volunteers in a smallholder family compound....

Figure 3.1 Data collection in a five-year-old E. grandis stand.

Figure 3.2 A two-year-old stand of E. grandis located in the study area. 34

Figure 3.3 Number of stands by age. 34

Figure 3.4 Number of stands by stand area 35

Figure 3.5 Number of stands by tree spacing. 36

Figure 3.6 Number of stands by local soil types. 37

Figure 3.7 Number of stands by topographic position. 37

Figure 3.8 Number of stands by land preparation techniques. 38

Figure 3.9 Tree nursery managed by forestry extension agents. 39

Figure 3.10 Family tree nursery specializing in E. grandis. 39

Figure 3.11 Number of stands by season of planting. 40

Figure 3.12 Number of stands by fertilizer type and use.

Figure 3.13 Number of stands by pesticide use.

Figure 3.14 Number of stands and time lapse between original planting and replanting.

Figure 3.15 Replanting E. grandis after fire incident.

Figure 3.16 Number of stands by type of stand management. 44 
Figure 4.1 Predicted volumes and 95\% confidence limits of the mean for E. grandis in the study area.

Figure 4.2 A comparison of volume yields from the study area and trials in South Africa...................................................... 52

Figure 4.3 A comparison of volume yields from the study area to trials in Zimbabwe.

Figure 4.4 A comparison of volume yields from the study area and trials in Hawaii.

Figure 4.5 A comparison of volume yields from the study area and trials at Aracruz Cellulose S.A. in Brazil...................................... 55

Figure 5.1 Five-year-old E. grandis stand in Pindoyu. 57 


\section{List of Tables}

Table 2.1 Local tree grade and associated price values for E. grandis............. 28

Table 3.1 Local tree grading system for E. grandis. ............................. 32

Table 3.2 Stand characteristics and silvicultural practices recorded for

E. grandis smallholder stands.......................................... 33

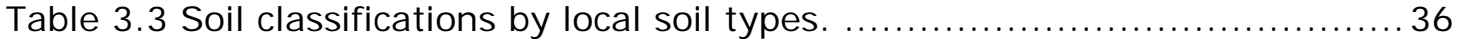

Table 3.4 Percentage of sampled trees reported by tree grade potential........... 45

Table 3.5 Average DBH and total height for individual trees reported by stand age.

Table 4.1 Pearson's correlation coefficient results. .............................. 47

Table 4.2 Dummy variables tested for significance $(p<0.05) \ldots \ldots \ldots \ldots \ldots \ldots \ldots . \ldots 48$

Table 5.1 Local tree grade and associated price values for E. grandis.............6 61 


\section{Acknowledgments}

I would like to recognize all the smallholders in Pindoyu who supported this research by allowing me to measure their eucalyptus stands and talk endlessly about forestry in eastern Paraguay. Thanks to all the forestry professionals in Caazapá for meeting with me, answering my questions, and taking me seriously even as I struggled to communicate in their native tongue, Guarani. I offer my deepest appreciation to all of my Paraguayan friends who made my life as a Peace Corps Volunteer easier and more enjoyable.

Thanks to Peace Corps Paraguay Staff, particularly Dr. Luz and Dr. Luis, for making it possible to live in a developing country with some of the comfort, safety and health benefits of the United States.

I am eternally grateful to Blair Orr for his steady guidance through the process of creating this thesis. His patient and thoughtful feedback, from formulating a research plan to turning research into a coherent thesis, was invaluable. Thanks also to Linda Nagel for her listening ear and guidance during the uncertain times of research in Paraguay. Thanks to Carol MacLennan for her open door, thought provoking conversations, and recommendations.

Always last and never least, I owe my curious spirit and ability to navigate through life and the world to my family for all their love and support in whatever crazy adventure, be it graduate school or the Peace Corps, I choose to undertake. 


\begin{abstract}
Smallholders in eastern Paraguay plant small stands of Eucalyptus grandis W. Hill ex Maiden intended for sale on the local market. Smallholders have been encouraged to plant E. grandis by local forestry extension agents who offer both forestry education and incentive programs. Smallholders who practice recommended forestry techniques geared towards growing large diameter trees of good form are financially rewarded by the local markets which desire saw log quality trees. The question was posed, are smallholders engaging in recommended silvicultural practices and producing reasonable volume yields? It was hypothesized that smallholders, having received forestry education and having financial incentives from the local market, would engage in silvicultural practices resulting in trees of good form and volume yields that were reasonable for the local climate and soil characteristics. Yield volume results from this study support this hypothesis. Mean volume yield was estimated at 70 cubic meters per hectare at age four and 225 cubic meters per hectare at age eight. These volume yields compare favorably to volume yields from other studies of E. grandis grown in similar climates, with similar stocking levels and site qualities.
\end{abstract}




\section{Chapter 1 Introduction}

Eucalyptus grandis W. Hill ex Maiden was introduced to Caazapá, Paraguay in the late 1990s and to Pindoyu, a settlement of Caazapá, in 2005. Since then, plantation forestry and the local Eucalyptus grandis market has been growing. Today smallholders in Pindoyu continue to plant E. grandis because they believe the expanding industry offers an opportunity for economic gain.

As a Peace Corps Volunteer in Pindoyu and a forestry student at Michigan Technological University, I was intrigued by the forestry practices of smallholders and the E. grandis market in Caazapá. I traveled around the region and interviewed wood processors, industrial plantation managers, forestry extension agents, and smallholders. I wanted to understand the role of E. grandis smallholders in Pindoyu in the broader forest economy of the region. Did smallholders understand and engage in recommended silvicultural practices? Were smallholder volume yields adequate? If so, did volume yield result in economic gains? These were the questions that spurred my research.

The objective of this study was three fold. The first objective was to examine stand characteristics of E. grandis and silvicultural practices of smallholders. The second objective was to determine stand volume yields and compare them to other studies. The third objective was to understand the significance of stand characteristics and silvicultural practices on stand volume yields.

Chapter two (background) briefly describes Paraguay, Caazapá, the settlement of Pindoyu, and Eucalyptus grandis as they relate to this study. Chapter three (methods) explains how data were sampled, measured and analyzed, and describes the silvicultural practices and stand characteristics in the study area. Chapter four (results) includes stand volume yields and compares 
these yields to other eucalyptus growth and yield studies. Chapter five (discussion) explores the similarities and differences among growth and yield study comparisons. Next, the significance of stand characteristics and silvicultural practices on volume yield are discussed. Chapter six (conclusion) ends with an explanation of the local market for Eucalyptus grandis and suggestions for future development efforts. 


\section{Chapter 2 Background}

\subsection{The Climate of Paraguay}

Paraguay is a landlocked country in South America, bordered by Bolivia to the north, Brazil to the east and Argentina to the south and west (Figure 2.1).

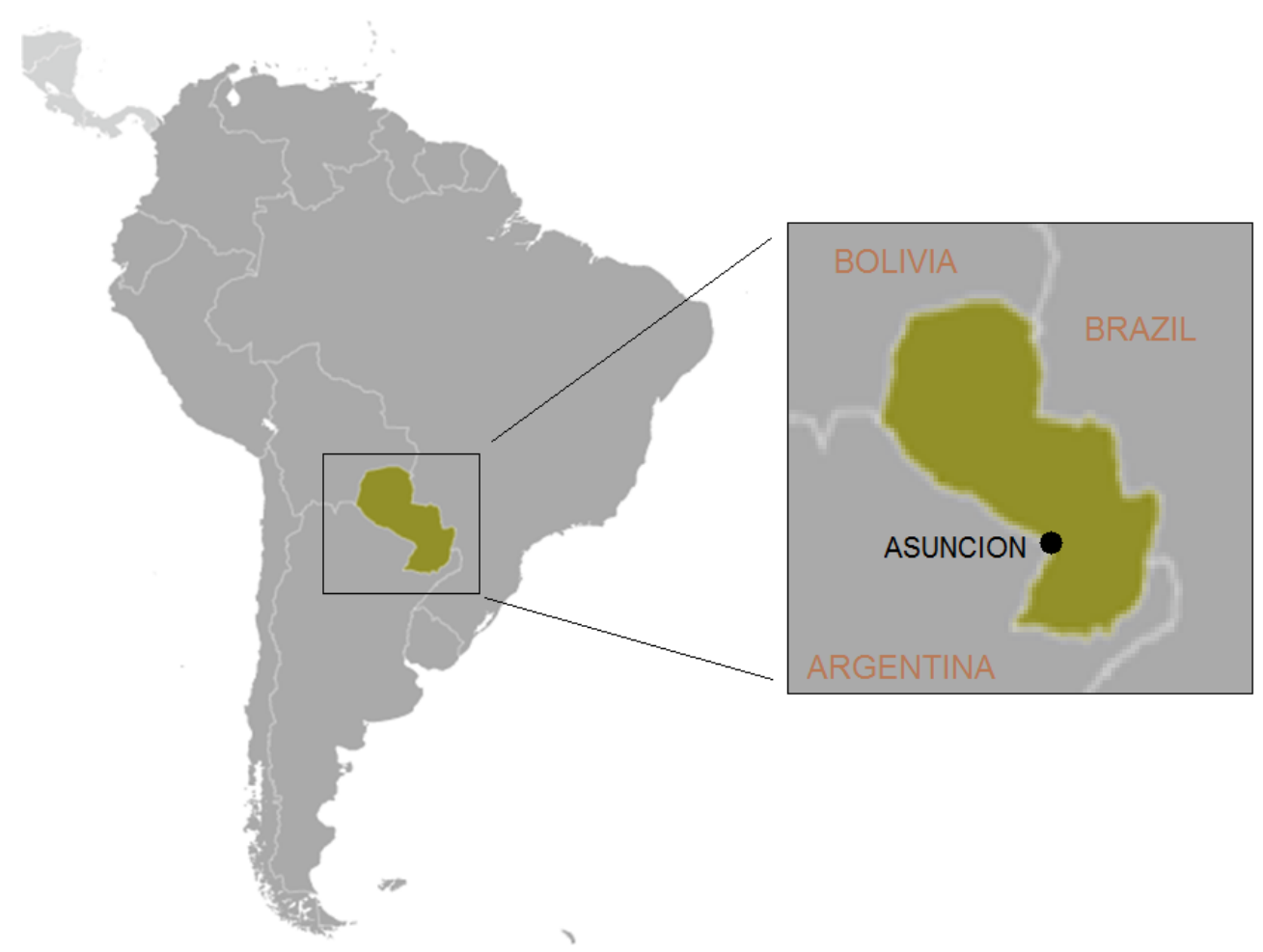

Figure 2.1 Paraguay's location in South America.

Base map from the public domain U.S. Central Intelligence Agency. Adapted by B. Alloway.

The total land area of Paraguay measures 406,752 square kilometers, approximately the size of California. The eastern region, Region Oriental, comprises forty percent of the total land area and is divided from the western region, Region Occidental or The Chaco, by the south flowing Paraguay River. The Chaco has a semi-arid to sub-humid climate with total rainfall averaging 400 $\mathrm{mm}$ /year that falls more frequently in the summer months, December, January and February. The eastern region has a more favorable climate for crop farming, 
with an abundance of rainfall (up to $1,700 \mathrm{~mm} / \mathrm{yr}$ ) equally distributed throughout the year. The average temperatures are $17^{\circ} \mathrm{C}$ in the winter months and $27^{\circ} \mathrm{C}$ in the summer months. A few frosts are typical in the winter (FAO, 2006). The climate is subtropical and humid, characterized as Cfa in the Koppen-Geiger climate classification (Kottck et al., 2006).

\subsection{The History and Economy of Paraguay}

Paraguay gained independence from Spain in 1811. For the following 150 years forty-four military dictators led Paraguay into political instability, economic uncertainty and war. During the Triple Alliance War, fought between 1865 and 1870, Paraguay lost one-third of its arable land to Brazil, Argentina and Uruguay

and lost two-thirds of its male population. Loss of population and land devastated the economic development of the country for decades.

Alfredo Stroessner, the forty-fifth military dictator to rule Paraguay, came to power in 1954 and held office for thirty-five years. Under his leadership the infrastructure and economy of Paraguay grew. The I taipu hydroelectric plant was established bringing electricity to Paraguay and Brazil. Highways were constructed allowing for transportation of commodities to and from river ports and the interior of the country. These commodities however, were mostly contraband from informal markets. Illegal exports had two-thirds the value of legal exports (Anon., 2006). Stroessner ruled with spies and secret police and the average citizen had few civil liberties. Land was seized from the rural poor and given to military officials, Stroessner supporters and foreign corporations (Stadius, 2012).

Paraguay became a constitutional republic after Stroessner was overthrown and exiled from the country in 1989. Eleven years later, in 2008, 
Stroessner's party lost power and the corruption and illegal activities that occurred during his dictatorship became public. Land distribution inequality was the highest in all of Latin America. The government had distributed sixty-four percent of the country's public and private lands to wealthy Paraguayans and foreigners (Stadius, 2012). Land seizures from the rural poor and title forgeries, combined with general disorganization, led to duplicate and triplicate land titles for a given property (Stadius, 2012). In 2013, land ownership was still uncertain. In an agrarian society land is vital to livelihood. Land inequality therefore affects the rural poor's ability to advance financially. In Paraguay income inequality is the highest in all of South America (ClA, 2013).

Thirty-five percent of the general population lives in poverty. The majority of the poor, though lacking economic opportunity and land resources, do have access to suitable housing, clean water, telephone services, and electricity as these resources are common in all areas of Paraguay for all socio-economic classes. Poverty is associated with lack of formal education, single-female heads of households, monolingual Guarani speakers, and migration (CIA, 2013).

In rural areas, past generations have not received formal education. Onethird of the current generation will complete elementary school and continue on to secondary school ( $7^{\text {th }}$ through $12^{\text {th }}$ grades), and a minute percentage $(0.5 \%)$ will continue and complete public university (Atlas Censal del Paraguay, 2002).

Paraguay is considered a bilingual nation with two official languages, Guarani and Spanish. However, language fluency and ability vary dramatically among regions and socioeconomic classes. Spanish is the language of business and commerce and Guarani is the language of the home and tradition. Rural populations, where Guarani is the first language, are more likely to be poor. Spanish second language learners are uncomfortable speaking in Spanish, making 
it more challenging to work in the formal business sector or find permanent employment.

There are few economic opportunities for the sixty percent of the population between the ages of fifteen and fifty-four that make up the labor force. Surplus land is not available and jobs are scarce, and so the labor force, particularly the percentage lacking land or education and living in poverty, emigrate to the cities of neighboring Brazil and Argentina (Fletschner and Zepeda, 2002; ClA, 2013). Those who stay in Paraguay will work as smallholder farmers because, in Paraguay's agrarian society, farming is one of the few economic opportunities for rural populations.

In 2006 ninety percent of all exports from Paraguay were agricultural crops. These exports accounted for $26 \%$ of the 25.5 billion dollar GDP (FAO, 2006). Primary agricultural exports were, in order of economic importance, cotton, sugarcane, soybeans, corn, wheat, tobacco, and cassava ( $\mathrm{ClA}, 2013)$. Industrial farmers and smallholder farmers contribute to the production of agricultural exports and the nation's GDP, as well as sell products on local markets. The average smallholder cultivates less than twenty hectares of land. Smallholders plant crops and raise animals for home consumption, and plant cash crops (like cotton) or grow surplus food crops (like corn) intended for sale or trade. In Paraguay, smallholders make up eighty percent of all farmers but have access to only seven percent of the arable land (FAO, 2006). Industrial farmers make up only one percent of the farmers yet they have access to seventy-seven percent of the arable land. Industrial farmers cultivate intact parcels of land larger than 1,000 hectares. The remaining nineteen percent of farmers cultivate land areas somewhere in between these two extremes. 
Industrial farmers produce the majority of soybeans and corn, and smallholders produce the majority of cotton. In the year 2000, cotton made up one-third of total exports, seventy percent of which was produced by smallholders on land parcels smaller than twenty hectares (Fletschner and Zepeda, 2002). Therefore cotton has greater economic importance for the smallholder than other agricultural products grown on mechanized farms.

Smallholders in rural Paraguay have grown cash crops on their lands for decades and will continue to do so because there is a market for agricultural products, and there are limited options for economic gains off of the farm. Farmland is a resource for rural communities to gain financially, and because neither agricultural land expansion nor land redistribution is possible (due to opposition by politicians and the country's elite), smallholders must manage their lands effectively (Fletschner and Zepeda, 2002).

\subsection{Description of Caazapá}

Six-and-a-half million people populate Paraguay, with the majority (98\%) living in the eastern region. The Department of Caazapá, one of the nation's seventeen departments, is located in the southeastern corner of the eastern region (Figure 2.2). 140,000 people inhabit Caazapá of which 115,000 (82\%) live in rural areas (Atlas Censal del Paraguay, 2002). Rural populations live in communities of traditional settlements separated by native forests and pasture and connected to one another by dirt roads. Larger access roads connect rural areas to the highway where the more densely populated towns are located. 


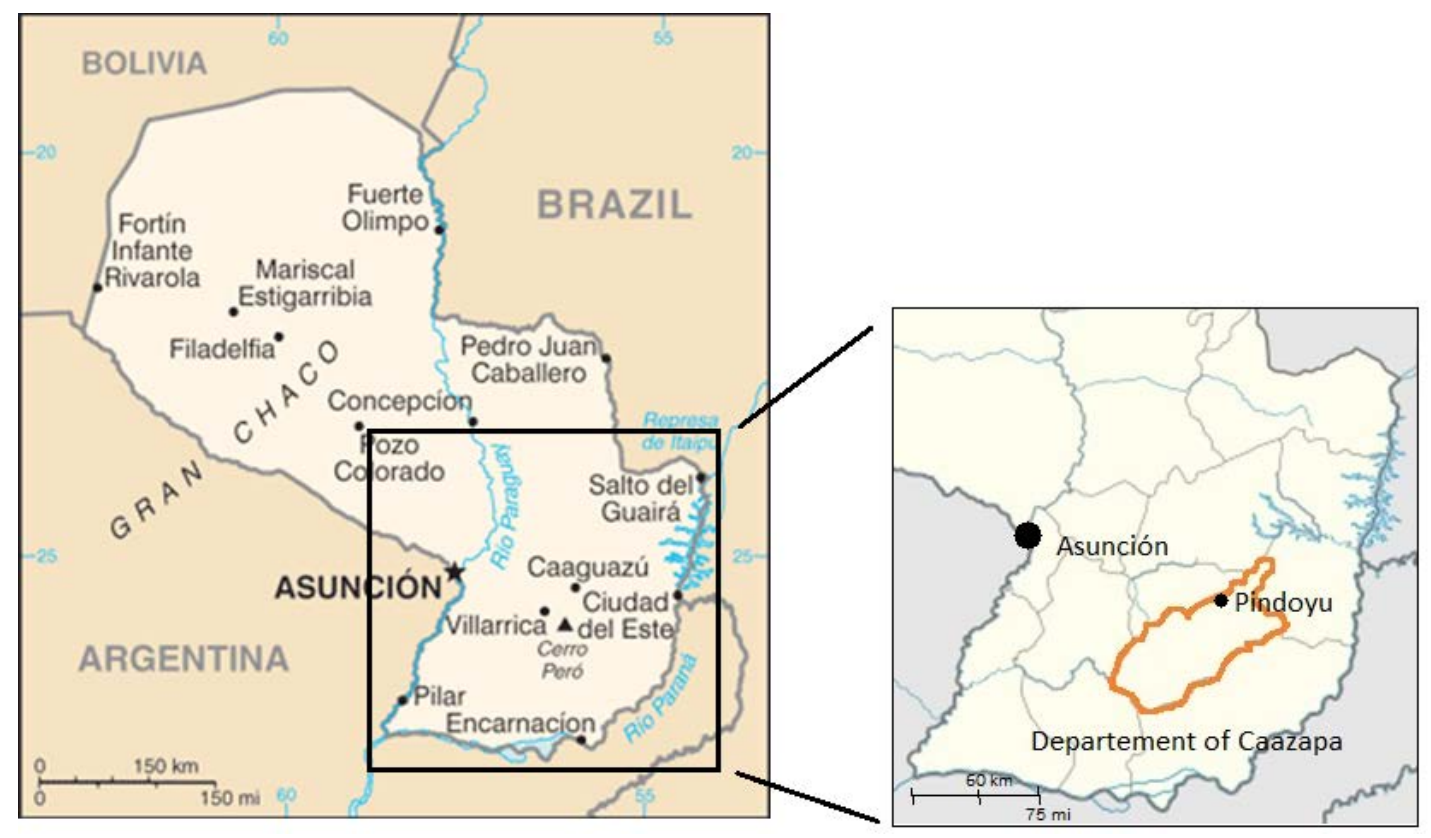

Figure 2.2 Paraguay, the Department of Caazapá, and the settlement of Pindoyu. Base maps from the public domains U.S. Central Intelligence Agency and Answers.com. Adapted by B. Alloway.

Traditional settlements are concentrations of households and associated yards, gardens, farm fields, and forests. The average number of people per household is five. The majority ( $75 \%$ ) of all households have electricity and some (20\%) have running water. The people cultivate lands and practice animal husbandry. Cows, pigs, sheep, fowl, and goats are common domesticated animals. Smallholders grow cassava (the staple carbohydrate), maize, beans, and peanuts in their fields for family consumption, and squash, melons, bananas, and a variety of vegetables in gardens located on family compounds. Cash crops grown in this region (in order by volume produced) are soy, sugar cane, maize, wheat, rice, cotton, and tobacco (Atlas Censal del Paraguay, 2002).

Caazapá, similar to other departments in the southern region, has been more densely populated for a longer period of time than departments in other regions of the country. The land here, though degraded after decades of over farming and mismanagement, was highly valued as it was relied upon for food 
and economic gains. Land access and land use were contentious as land ownership was uncertain, land fragmentation was common, and a growing presence of squatters were demanding rights to the land (Fletschner and Zepeda, 2002).

\subsection{Description of Pindoyu}

Pindoyu is a community of smallholders in Caazapá located at latitude $26^{\circ} 03^{\prime} \mathrm{S}$ and longitude $56^{\circ} 01^{\prime} \mathrm{W}, 150$ meters above sea level. Pindoyu is three square kilometers in size with a population of 500 people living in 100 households. This community is typical of the area except that it has better access to amenities. There is a high school and an elementary school with parent-teacher associations, a church organized by a church council, a health post maintained by a local health committee, a few stores, and two farmer organizations. The majority of households have electricity (90\%) and running water (75\%).

Pindoyu residents are smallholders who cultivate between one and twenty hectares of land located on the outskirts of town (Figure 2.3). Farming is nonmechanized with the exception that, once a year, the General H. Morinigo County government provides a tractor for tilling farmland. Those who have money to pay for the gas and have land accessible by tractor can choose to have their fields plowed. However, the correct time for plowing versus the timing of a tractor visit may not coincide. Therefore, oxen and plow are more commonly used to till soil (Figure 2.4). Nuclear families work within their larger extended families to manually plant and harvest crops, when many bodies are needed. 


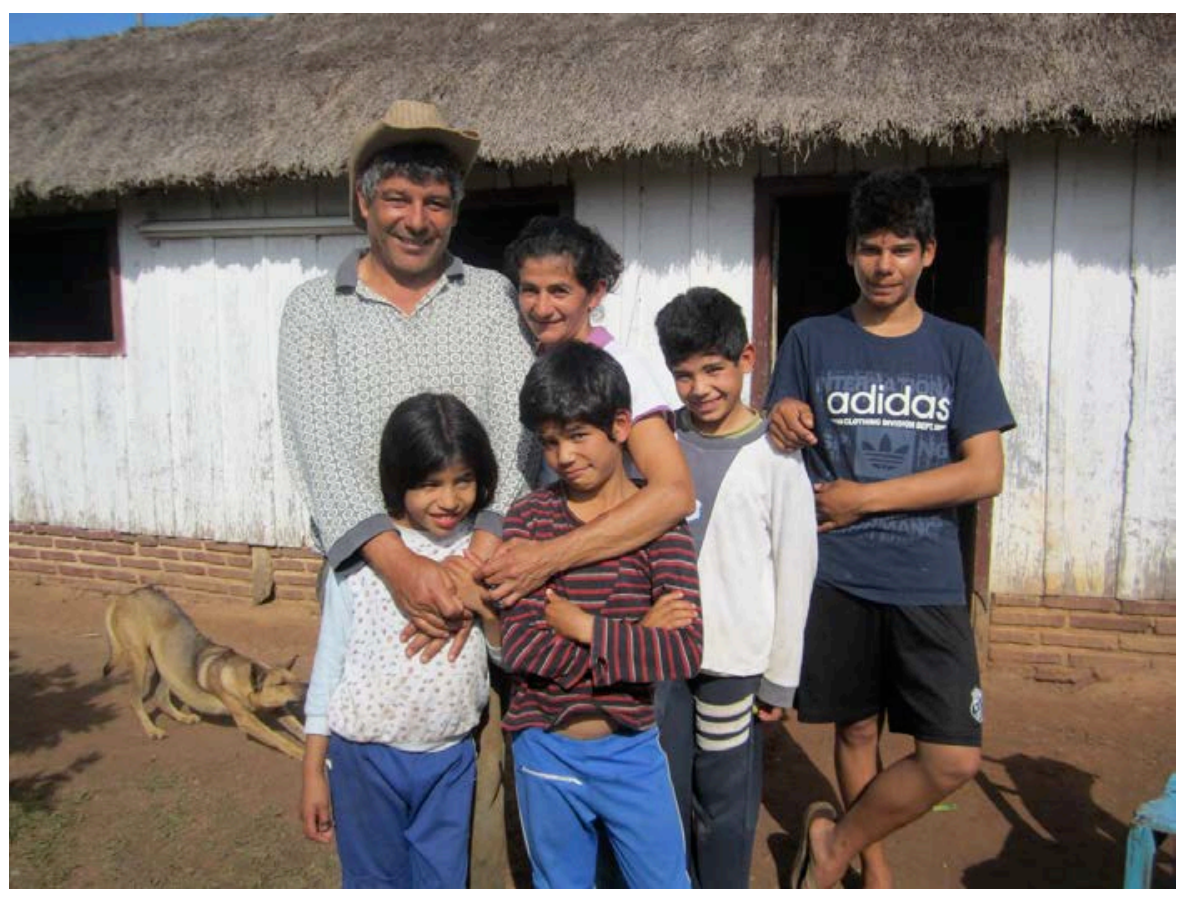

Figure 2.3 A typical smallholder family in Pindoyu, Caazapá. Photo by B. Alloway.

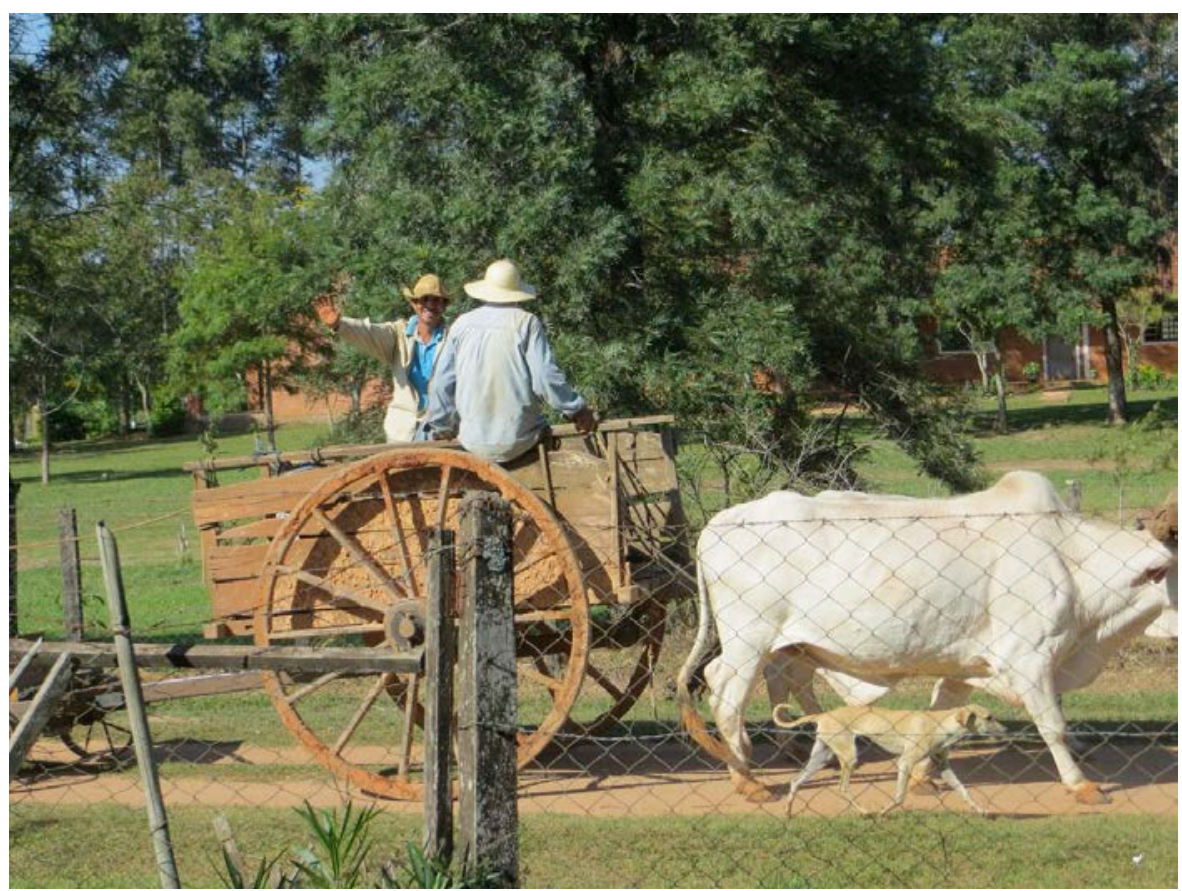

Figure 2.4 Smallholders heading to their farm fields to till soil with oxen. Photo by B. Alloway. 
Smallholders with access to fewer than five hectares of land have a portion of the land always planted with staple food crops and a portion left fallow or planted with a cover crop for future use. If one hectare of land is still available it may be dedicated to growing cash crops. Smallholders with more than five hectares of land are able to diversify agricultural practices. A few hectares are planted with food crops and a few hectares are left fallow. Surplus land is rented out to the landless, left with its natural forest cover for harvesting firewood and timber, used to graze animals, or used to grow cash crops. The more land smallholders have access to, the more they can diversify and use the land in a combination of these practices.

Pindoyu has a long history of reliance on farmland for food and cash crop production, and animal husbandry. The town was settled in the 1920s, the location chosen for its proximity to a new train line connecting a port town on the Rio de Oro to the capital city, Asuncion. Residents sold wood from the native forests to the train company, which either used the wood to power the steam engines or sold the wood for profit in the cities. Once the town and farm fields were established, residents began to sell surplus food crops to the train company as well. In the late 1980 s and early 1990s, Pindoyu residents were no longer able to rely on the sale of wood or surplus food crops for three reasons. First, the government shut down the train in order to redirect funds to highway construction. Second, industrial farming in Paraguay was growing steadily. Third, the global market was beginning to have an effect on the local economy. The average smallholder could no longer financially compete. Thereafter, smallholders in Pindoyu turned to growing cotton, and those with larger areas of land also grew yerba mate and invested in the production and sale of animal products and byproducts. 
In the 1990s, while sugar cane, wheat and rice were adopted in other areas of Caazapá, cotton became the most widely adopted cash crop in Pindoyu. Originally smallholders designated up to one hectare of land for cotton production but since the year 2000, smallholders in Pindoyu have dedicated less of their lands for cotton production as the economic rate of return has declined.

The market price for cotton fell due to local and global levels of competition. Pesticides became needed for weed control and paid laborers were needed for harvest. After subtracting these costs from the total revenue, smallholders were barely breaking even. The economic demise of cotton is reflected in the $50 \%$ decrease of cotton production by smallolders in Caazapá between the early 1990s to the year 2002 (Atlas Censal del Paraguay, 2002). In 2013 cotton production continued to decline in Pindoyu and the greater surrounding area.

Smallholders in Pindoyu have relied on cash crops and other farm related products for income generation for nearly a century. They are aware that the market for products rises and falls and prices fluctuate. Therefore, smallholders rely on multiple products and use multiple strategies for annual income generation. The diversification of these farm products and strategies helps smallholders mitigate their losses if one crop or product fails.

Grazing land will be used to raise cattle, sheep, goats, pigs and chickens. To further diversify production, some cows will be raised for meat production and others for milk production. Similarly, some chickens will be raised for meat production and others for egg production. All of these animals or animal by products can then be consumed by the household or sold in town.

The same concept is true for diversification of cash crops. A variety of annual crops will be planted, such as cotton and stevia (Stevia rebaudiana). 
Yerba mate, Ilex paraguariensis, a native shrub that's leaves are used for a ubiquitous local tea production is planted, and after two years can be pruned and leaves then sold annually. Smallholders with native woodlots see their trees as another cash crop that can be sold to neighbors for fuel wood or fence posts.

Smallholders with approximately twenty hectares diversify their farming practices as innovative strategies for further profits. These smallholders rely on the productivity of their lands as their household economy in contrast to smallholders with less than twenty hectares.

Smallholders with less than twenty hectares of land may also diversify their farming practices, but not nearly to the extent as those with access to more land. Smallholders with less land diversify farming practices primarily for risk mitigation and predominantly cultivate their land to grow food crops or raise animals for home consumption.

The household economy of these smallholders relies on someone in the family to work off of the farm. Some smallholders work as masons, electricians or carpenters doing odd jobs around town. Other smallholders receive money from family members who have migrated to larger cities in Brazil or Argentina and perform service or construction work. That said, all smallholders farm their land for home consumption purposes and the majority dedicate some portion of land for the production of at least one cash crop.

Sugar cane, wheat and rice became the economically important cash crops in Caazapá in the 1990s (Atlas Censal del Paraguay, 2002) and remained so in 2013. In Pindoyu however, it was impractical to invest in sugar cane, wheat or rice because farming was not mechanized and land ownership was fragmented. Smallholders in Pindoyu continued to rely on their land for economic gain; while 
cotton bottomed out, smallholders began planting and experimenting with other cash crops, such as stevia and Eucalyptus grandis (Figure 2.5).

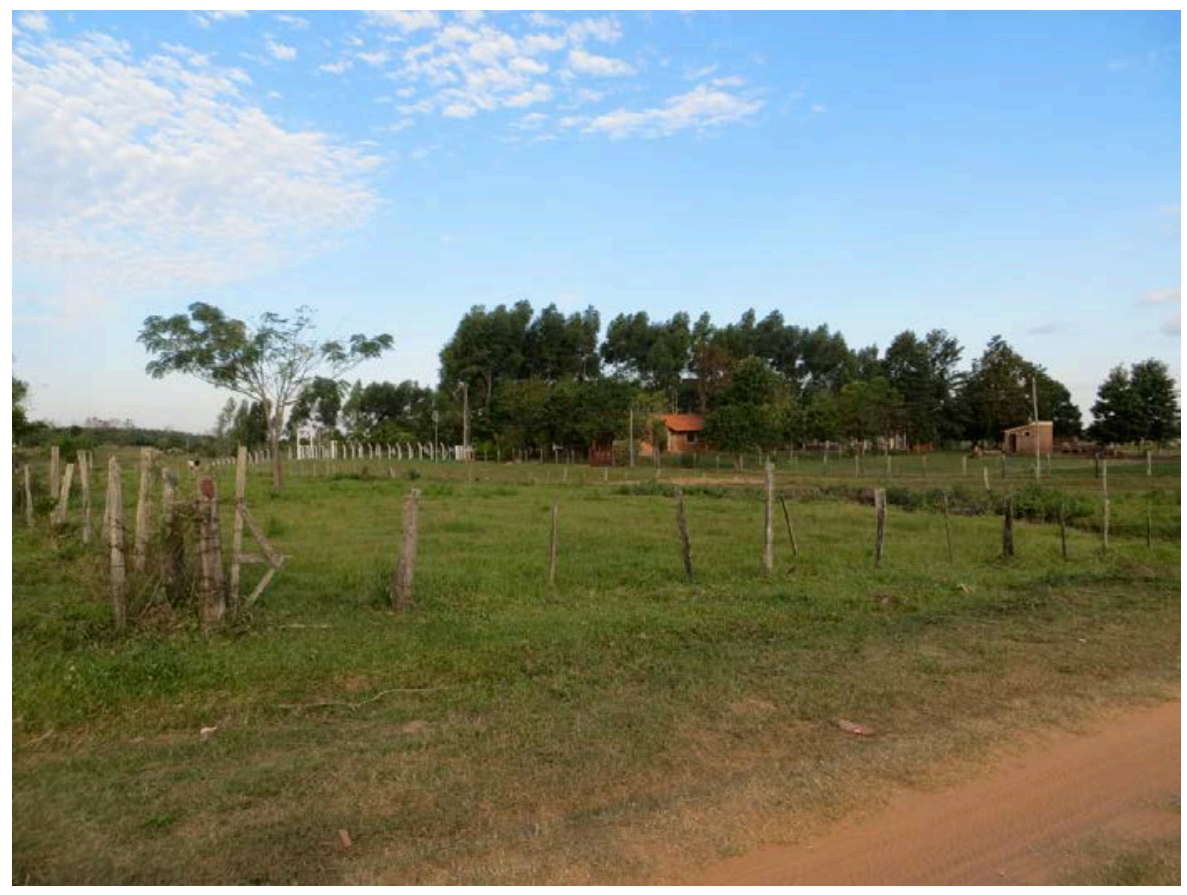

Figure 2.5 Smallholdings in Pindoyu include E. grandis, pasture land, and family compounds. Photo by B. Alloway.

Only some smallholders are willing or able to dedicate a proportional amount of land (determined by total land area) to the production of Eucalyptus grandis because the first economic returns from this cash crop are not realized until five years after planting, and the major economic return is not realized until ten years after planting at time of final harvest. Smallholders who dedicate an area of land for the production of E. grandis have other means for income generation for the short term, whether that is off the farm labor or lands dedicated for cash crops with a more immediate return. 


\subsection{Eucalyptus grandis W. Hill ex Maiden}

Eucalyptus is a tree genus in the myrtle family. This genus is largely native to Australia with a few species found in Maritime Southeast Asia and Papua New Guinea. There are over 600 species of eucalyptus that have adapted to numerous sub-climates in Australia, some are shrubs adapted to arid deserts and others are tall trees adapted to the humid tropics. A dozen of the 600 species have become world favorites and are now growing in over eighty countries.

Export of Eucalyptus spp. for ornamental planting trials began in the $1800 \mathrm{~s}$ but it was not until the mid 1900s that Eucalyptus spp. were aggressively exported and propagated around the globe (Doughty, 2000). Since then the planting of eucalyptus has increased and in the tropics, which encompasses forty percent of the world's plantations, eucalyptus species populate roughly half of all plantations (Evans and Turnbull, 2004).

A Brazilian entrepreneur, Edmundo Navarro de Andrade, first introduced eucalyptus species to South America. In the early 1900s, Navarro predicted a future need for reliable resources of wood for tracks, posts and power to aid in the growth of the recently introduced steam engine. Experiments with eucalyptus species began in the early 1900 s and continued with demonstration plots into the 1920s. By the 1940s, Navarro's compatriots had followed suit and over 200 million trees were planted in Brazil. Other South American countries began to take notice of eucalyptus but the introduction and adoption rate was later and slower.

Eucalyptus species were introduced to neighboring Paraguay sometime in the 1940 s or 1950 s with ten species being reported as acclimated by 1955 (Doughty, 2000). By 1965 there were 600 hectares of eucalyptus, pines, and native tree plantations. In the 1980s, over one thousand hectares of plantations were established increasing to 7,000 hectares by the 1990s. In 2000, an 
estimated 27,000 hectares were present (Evans and Turnbull, 2004) increasing to 43,000 hectares by 2005 (Frey, 2007). In 2004 eucalyptus was the most common plantation tree in Paraguay (Evans and Turnbull, 2004).

The most common species of the eucalyptus genus planted in Paraguay are Eucalyptus grandis, Eucalyptus urophylla, and Eucalyptus camadulensis.

Eucalyptus grandis is the most widely planted and promoted eucalyptus species. It is favored in all of the tropics for its rapid growth, its relative ease of care, and its multiple uses. E. grandis can be used for producing pulp, light construction lumber, charcoal, firewood, posts and poles and it is also melliferous (Doughty, 2000).

E. urophylla is valued for a straight and branch-free bole and dense wood quality. This species is being crossbred with E. grandis, renowned for rapid growth, making E. urophylla hybrids and clones popular among industrial solid wood plantations and processors. E. camadulensis is favored for riparian lowlands, where other crops and many trees cannot survive. This species is valued for posts, poles, firewood, and timber and pulp production (Doughty, 2000).

Shell Forestry Technical Services created the first eucalyptus plantation in Caazapá, with progeny trials of E. grandis. The goal was to produce timber for solid wood production. In 1998 this was innovative, as eucalyptus were commercially grown for pulp production. The plantation has since grown to 6,000 hectares. It is currently owned and managed by Pomera Maderas, an Argentine forestry company (Brawner and Elizual, undated). Pomera Maderas is the largest commercial plantation in the area. They export timber to Argentina and sell timber on the local market to value added industries. 
The National Forest Service of Paraguay, Instituto Forestal Nacional, (INFONA) has a three-fold interest in Eucalyptus grandis. It owns and manages eucalyptus woodlots and nurseries for experimentation and production, promotes and offers incentives for large-scale commercial plantations, and holds instructional workshops for local farming organizations. INFONA began working with E. grandis in Caazapá in the early 2000s, creating tree nurseries, planting eucalyptus woodlots, and partnering with like-minded interest groups. In 2004 they began working with local farming organizations in the region(R. Acuna, INFONA, Paraguay, personal communication).

In 2005, a forestry extension agent from INFONA arrived in Pindoyu to work with Committee Santa Cecilia, a small farming organization (Figure 2.6). The extension agents held workshops regarding best management practices for growing Eucalyptus grandis. Smallholders who participated in all the workshops were rewarded with free seedlings and a small stipend of money to purchase pesticides and fertilizers. In total four smallholders ended up completing the instructional sessions and planting E. grandis. Two years later, in 2007, a politically connected member of the elite, with the help of a hired independent forestry technician, established an E. grandis woodlot of one hundred and twenty hectares on the outskirts of Pindoyu. The forestry technician managed hundreds of hectares of E. grandis on his own land and planted and managed eucalyptus woodlots for other investors. 


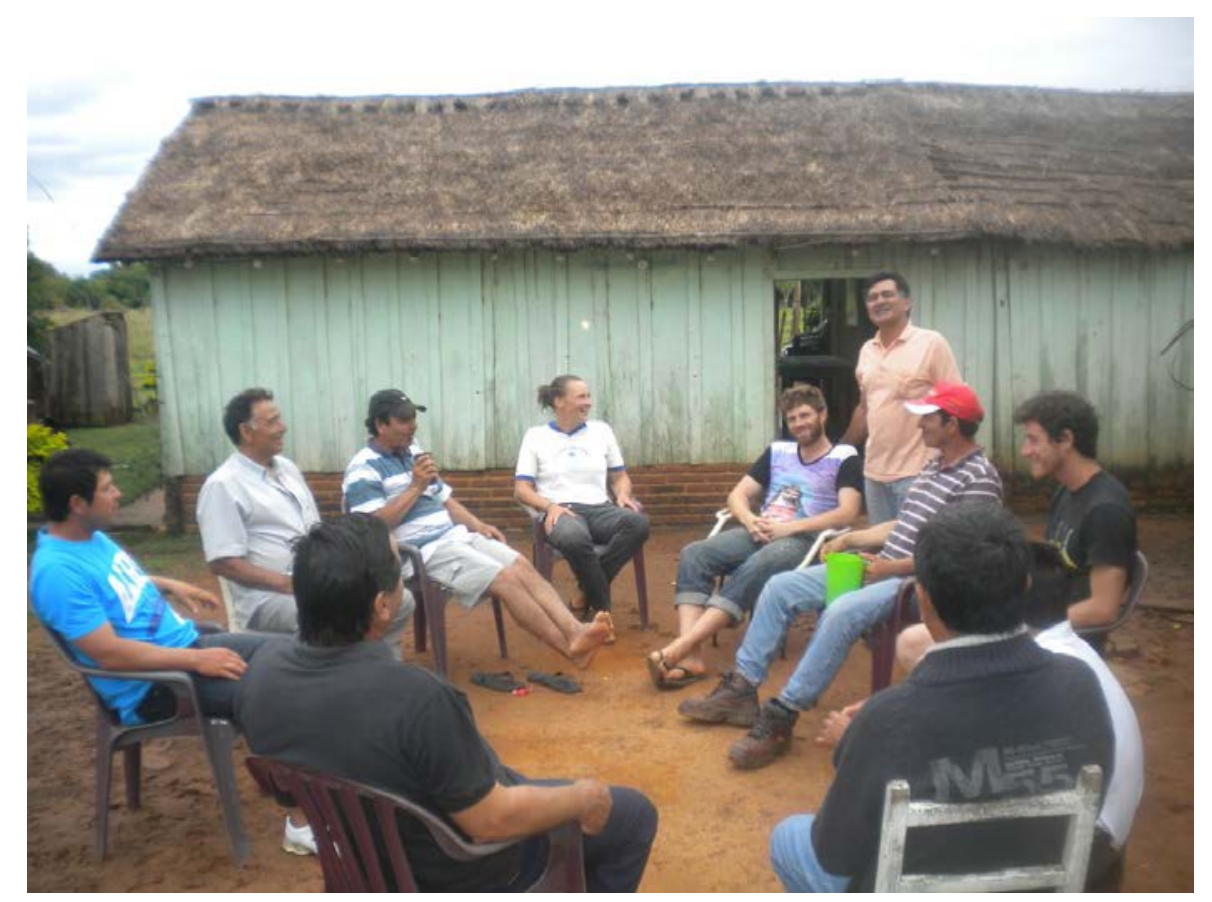

Figure 2.6 Committee Santa Cecilia meeting with Peace Corps Volunteers in a smallholder family compound. Photo by Nancy Alloway, used with permission.

In 2013, fifteen years after the first E. grandis stands were planted in the area, the local market for E. grandis consists of value added industries such as flooring or plywood factories, carpentry shops making furniture and housing materials, and sawmills that cut and re-sell lumber for construction. Wood processors in the area rely on E. grandis woodlots for their timber supply because the native tropical forests in the area have either been clear-cut or high graded.

The local market needs sawlog quality trees. Therefore, a local tree grading system is used (Table 2.1) and trees with larger diameters and good form are more valued than trees with smaller diameters of poor form. 
Table 2.1 Local tree grade and associated price values for E. grandis

\begin{tabular}{clcc} 
Tree Grade & \multicolumn{1}{c}{ Description } & $\begin{array}{c}\text { Value } \\
\text { Local Currency } \\
\text { (Guaranies) }\end{array}$ & $\begin{array}{c}\text { Value } \\
\text { (US Dollars) }\end{array}$ \\
\hline 1 & $\begin{array}{l}21 \mathrm{~cm} \text { diameter at } 11 \mathrm{~m} \\
\text { First } 11 \mathrm{~m} \text { straight and } \\
\text { branch free }\end{array}$ & 523,000 & 119 \\
2 & $\begin{array}{l}19 \mathrm{~cm} \text { at DBH. First } 11 \mathrm{~m} \\
\text { relatively straight and } \\
\text { few branches } \\
\end{array}$ & 163,000 & 37 \\
\hline & $\begin{array}{l}<19 \mathrm{~cm} \text { at DBH } \\
\text { poor form }\end{array}$ & $<90,000$ & $<20$ \\
\hline
\end{tabular}

The local market for E. grandis is diverse and different end users have different requirements. All trees exported to Argentina by Pomera Maderas must be grade one quality, but local carpentry shops buy grade two quality timber for production of smaller items. These carpenters do not need trees of large diameter and will purchase grade two trees produced at time of final harvest and trees thinned from stands during intermediate treatments. One factory in the area will purchase grade three trees for chipping to be transported to factories in Asuncion. Therefore, there is a market for trees of differing diameter classes and varying form, however trees with large diameters of good form will net the smallholder the most profits.

These factors have contributed to recent growth in interest from Pindoyu smallholders in E. grandis. The industry became visible through the transportation of large timber along service roads and highways when the first mature stands at Pomera Maderas were harvested. Value-added companies began to spring up in the area seeking mature E. grandis, and local lumber mills switched from purchasing native timber to purchasing Eucalyptus grandis. The growing industry and market were new and visible, inspiring smallholders to invest. Independently 
wealthy citizens were purchasing and dedicating up to 300 hectares of land for the planting of E. grandis. These changes led the local smallholder to believe there was economic potential in eucalyptus woodlots. This perception was further strengthened through workshops offered by INFONA, services offered by independent forestry technicians, and informal conversations among smallholders. In 2013 , at the time of this study, eighteen woodlots were located on the outskirts of Pindoyu and dozens more were being planted just outside its boundaries. With greater access to forestry resources and a growing timber market smallholders could no longer resist the temptation to plant, tend and manage E. grandis woodlots. 


\section{Chapter 3 Methods}

\subsection{Sampling Procedure}

The study area includes all eighteen E. grandis woodlots on the outskirts of Pindoyu, interspersed among farm fields and native forests and located within five kilometers of one another. Six of the woodlots incorporated more than one stand, delineated primarily by age class. Single stand woodlots or one stand per woodlot, chosen at random, was sampled in this study $(\mathrm{N}=18)$. The data were collected in 2013.

For every stand, sample plot locations were determined using a random number table. The stand boundary (of ten meters) was omitted from the sample area because stands were bordered by open spaces, farm fields or native forests and thus trees in the stand boundaries were less representative of the stand in general. For each stand two fixed ten-meter by ten-meter plots were sampled per hectare (Figure 3.1). For stands of less than one hectare, two plots were also sampled, the exceptions being the two eight-year old stands of 0.13 hectares. In these stands one third of all trees, chosen at random, were sampled and individual tree data were collected in the same manner as in the fixed plots. Within each fixed plot every tree was measured for diameter at breast height (DBH) (1.3 m above ground on upward slope). All trees with a DBH of less than one centimeter were counted but no further measurements were taken. Trees with a DBH greater than one centimeter were measured for total tree height, branch height, tree grade, and crown position. Total tree height and branch height were determined using a clinometer. Tree grades were determined using local standards for tree purchase. See appendix A for stand characteristics data and silvicultural practices data. 


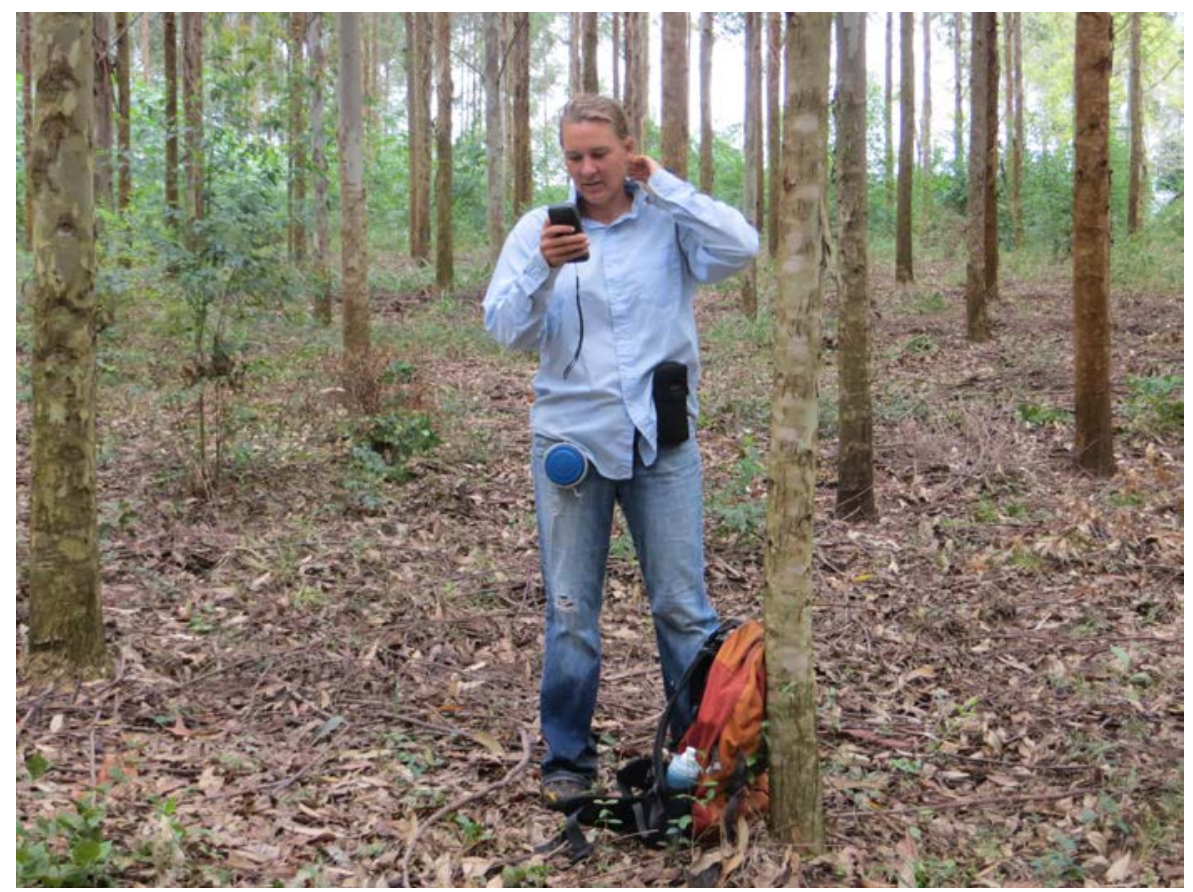

Figure 3.1 Data collection in a five-year-old E. grandis stand. Photo by Nancy Alloway, used with permission.

For E. grandis in southeastern Paraguay local standards for tree grading are as follows. A tree grade of one signifies a tree most desired by local lumber mills. Minimum requirements for this tree grade are numerous straight and branch free sections of two and a half meters along the bole. A minimum of a twenty-one centimeter diameter at eleven meters is required at time of harvest. A tree grade of two requires a $\mathrm{DBH}$ of nineteen centimeters or greater at time of harvest. The first eleven meters of the bole may have minimal branching and must have, at minimum, one straight section of two and a half meters. Grade two trees are still usable by local lumber mills but less desirable. A tree grade of three signifies a tree of no value to a local lumber mill due either to poor form, excessive branching or a projected DBH of less than nineteen centimeters at time of harvest (Table 3.1). Younger trees with smaller diameters must show vigor and ability to attain required diameter measurements in future years. While this tree 
grading system is informal, it is applied locally and understood among buyers and sellers.

Table 3.1 Local tree grading system for E. grandis.

\begin{tabular}{cl} 
Tree Grade & \multicolumn{1}{c}{ Description } \\
\hline 1 & $\begin{array}{l}21 \mathrm{~cm} \text { diameter at } 11 \mathrm{~m} \\
\text { First } 11 \mathrm{~m} \text { straight and } \\
\text { branch free }\end{array}$ \\
& $\begin{array}{l}19 \mathrm{~cm} \text { at DBH. First } 11 \mathrm{~m} \\
\text { relatively straight and } \\
\text { few branches } \\
\end{array}$ \\
& $\begin{array}{l}<19 \mathrm{~cm} \text { at DBH } \\
\text { poor form }\end{array}$ \\
\hline
\end{tabular}

\subsection{Stand Characteristics and Silvicultural Practices}

Supplemental information regarding stand characteristics and silvicultural practices were obtained through personal observations or from various sources. Categorical information was numerically coded (Appendix A). Stand characteristics and silvicultural practices of interest to this study are reported in Table 3.2. 
Table 3.2 Stand characteristics and silvicultural practices recorded for E. grandis smallholder stands.

\begin{tabular}{ll} 
Stand Characteristics & Silvicultural Practices \\
\hline Stand Age & Tree Spacing \\
Stand Area & Seedling Origin \\
Stand Ownership & Season of Planting \\
Stand Management & Fertilizer Use \\
Number of Stands & Time lapse between Planting \\
on the Plantation & and Replanting \\
& Pesticide Use \\
& Land Preparation \\
& Soil Type \\
& Topographic Position \\
& Thinning Practices \\
\hline
\end{tabular}

On average, woodlots were owned and self-managed by the smallholder. Six of the eighteen woodlots incorporated multiple stands. These stands were primarily delineated by age class. Stands were between one-half to one hectare in size, and young. Stands were planted at a $3 \mathrm{~m} \times 3 \mathrm{~m}$ spacing in the winter months on flat, fertile farm soils without the use of fertilizers. If replanting was practiced it occurred within the first three weeks of initial planting. Tractors were used to prepare land after which, pesticides and manual weeding were practiced until crown closure. Figure 3.2 is an E. grandis stand at age two, representative of stand characteristics and silvicultural practices in the study area. 


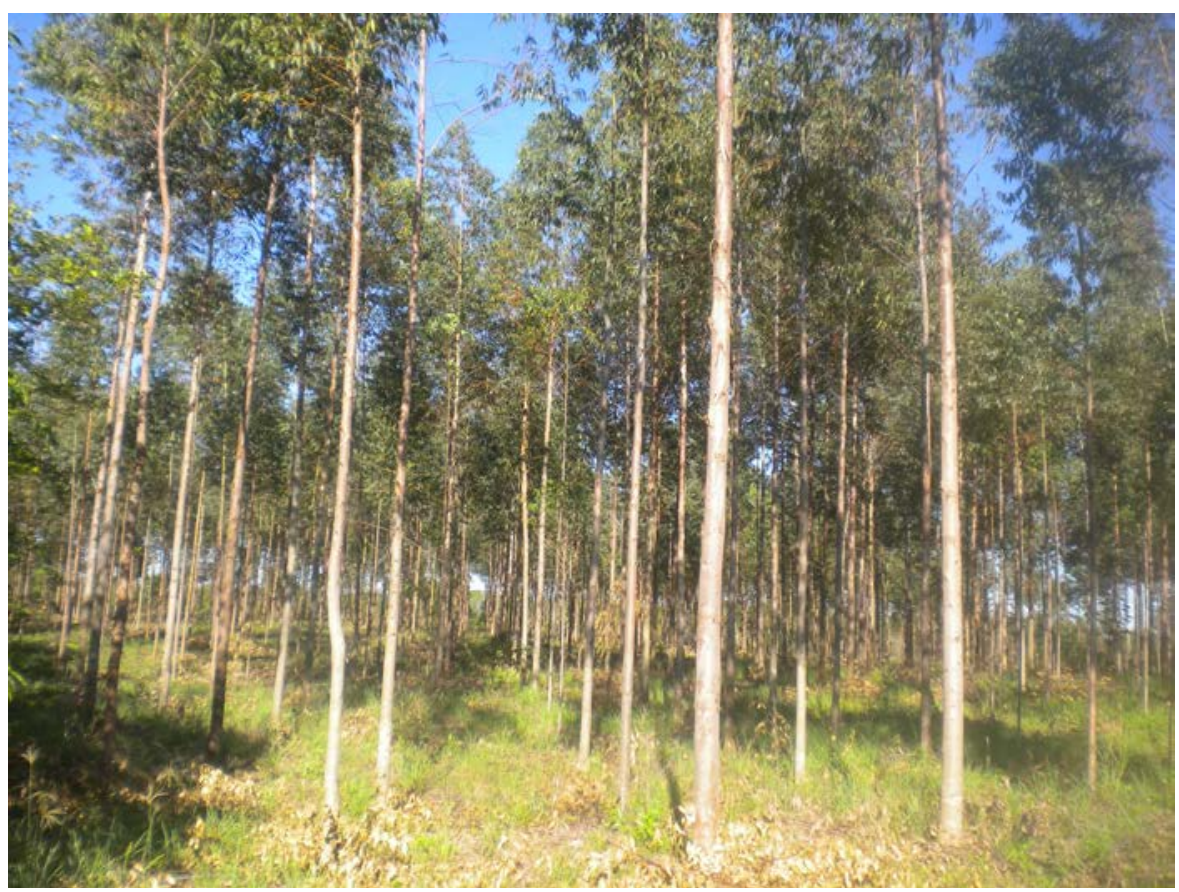

Figure 3.2 A two-year-old stand of E. grandis located in the study area. Photo by B. Alloway.

The stand age ranged from one to eight years with the majority of stands falling between the ages of two and five (Figure 3.3).

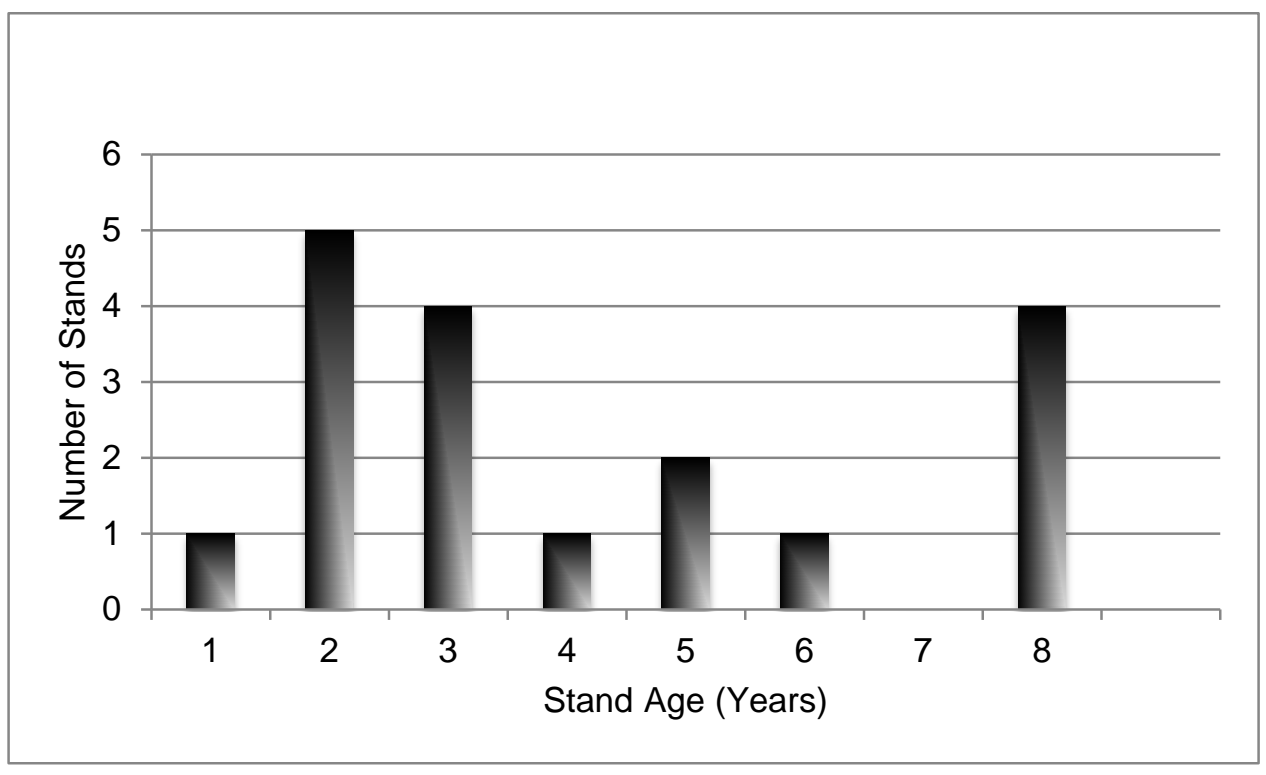

Figure 3.3 Number of stands by age. 
Stand area varied in size from 0.13 to 2.5 hectares, with a median stand size of 1.15 hectares (Figure 3.4). Six stands, delineated by age, were part of larger woodlots. The largest woodlot was 120 hectares, an anomaly for the area yet understandable because the plantation owner was a wealthier citizen of the elite class. The other five woodlots ranged in size from 1.5 to 6.5 hectares. These woodlots included stands of newly planted E. grandis (less than five months of age in 2013) and stands of seven-year old E. grandis. The majority of all stands on the six plantations however, were between one to three years old.

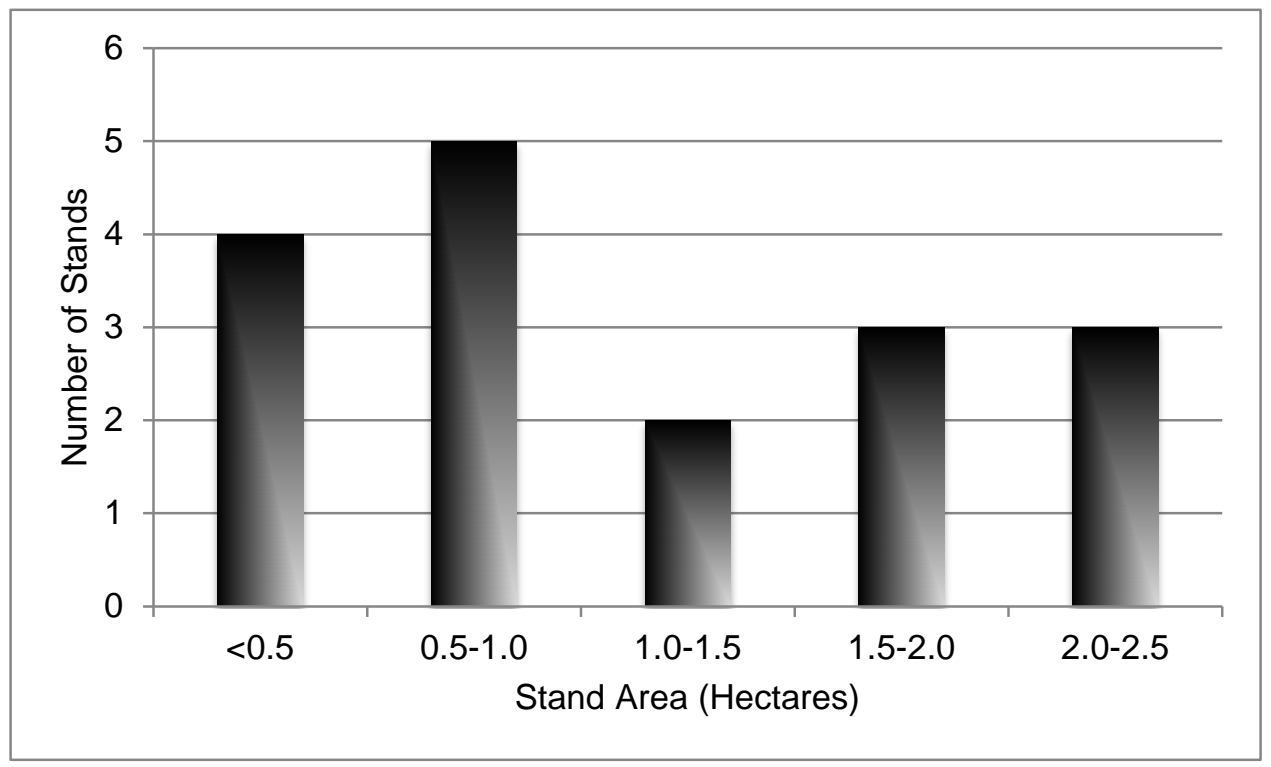

Figure 3.4 Number of stands by stand area

The majority of the stands had a $3 \mathrm{~m} \times 3 \mathrm{~m}$ spacing between trees or 1,111 trees per hectare. Four stands were planted at different spacings, from $2 \mathrm{~m} \times 2 \mathrm{~m}$ to $3 \mathrm{~m} \times 2.75 \mathrm{~m}$ (Figure 3.5 ). 


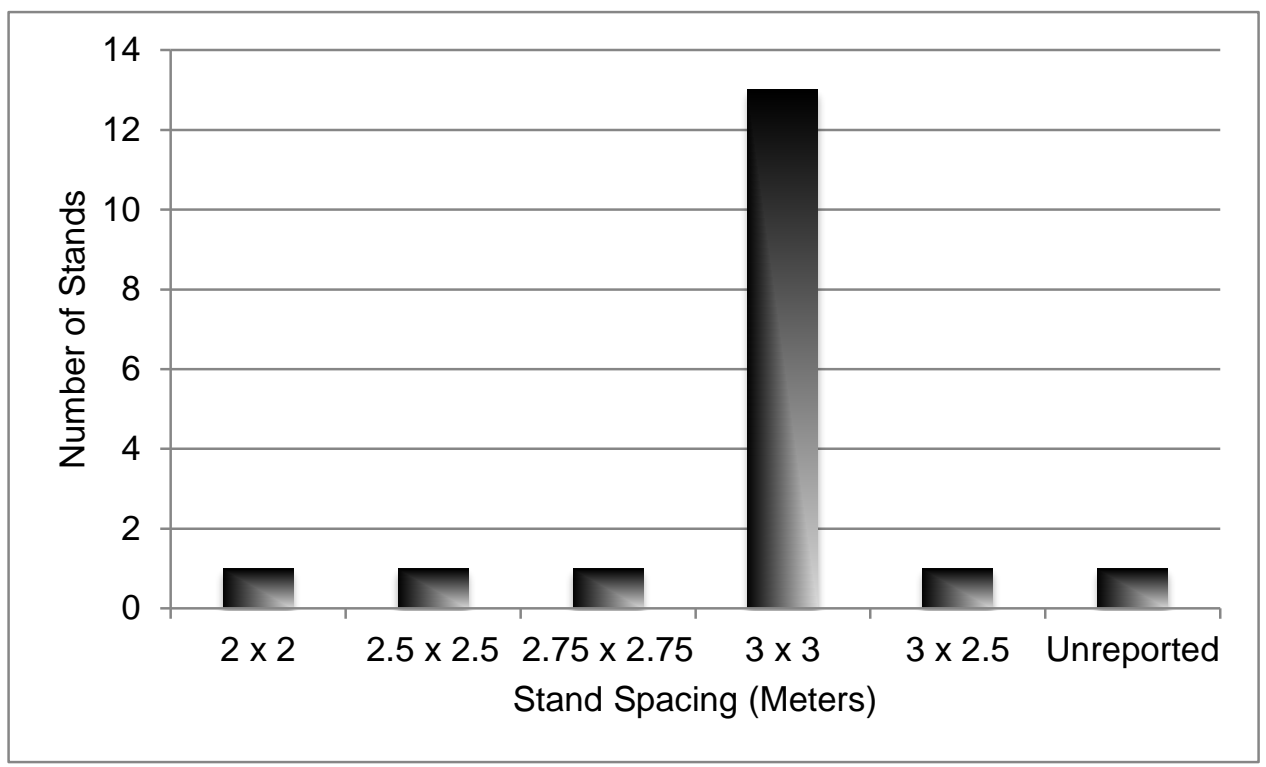

Figure 3.5 Number of stands by tree spacing.

Soil type was classified into four categories using local classifications (Table 3.3). Six stands grew on yvy pyta, three stands on yvy rosada, three stands on yvy moroti, and two stands on yvy hu. Data were not obtained for four stands (Figure 3.6).

Table 3.3 Soil classifications by local soil types.

\begin{tabular}{|c|c|c|}
\hline $\begin{array}{l}\text { Name of Soil } \\
\text { in Guarani }\end{array}$ & $\begin{array}{l}\text { Name of Soil } \\
\text { in English }\end{array}$ & Description \\
\hline Yvy Pyta & Red Soil & $\begin{array}{l}\text { This soil is considered to have ample nutrients, } \\
\text { decent drainage and is the desired soil for farming }\end{array}$ \\
\hline Yvy Rosada & Pink Soil & $\begin{array}{l}\text { Considered nutrient rich with better drainage } \\
\text { properties than Red Soil }\end{array}$ \\
\hline Yvy Moroti & White Soil & $\begin{array}{l}\text { Considered nutrient depleted with less ability to } \\
\text { retain soil moisture than Red or Pink Soils }\end{array}$ \\
\hline Yvy Hu & Black Soil & $\begin{array}{l}\text { Considered somewhat nutrient depleted, } \\
\text { mud like, with poor drainage }\end{array}$ \\
\hline
\end{tabular}




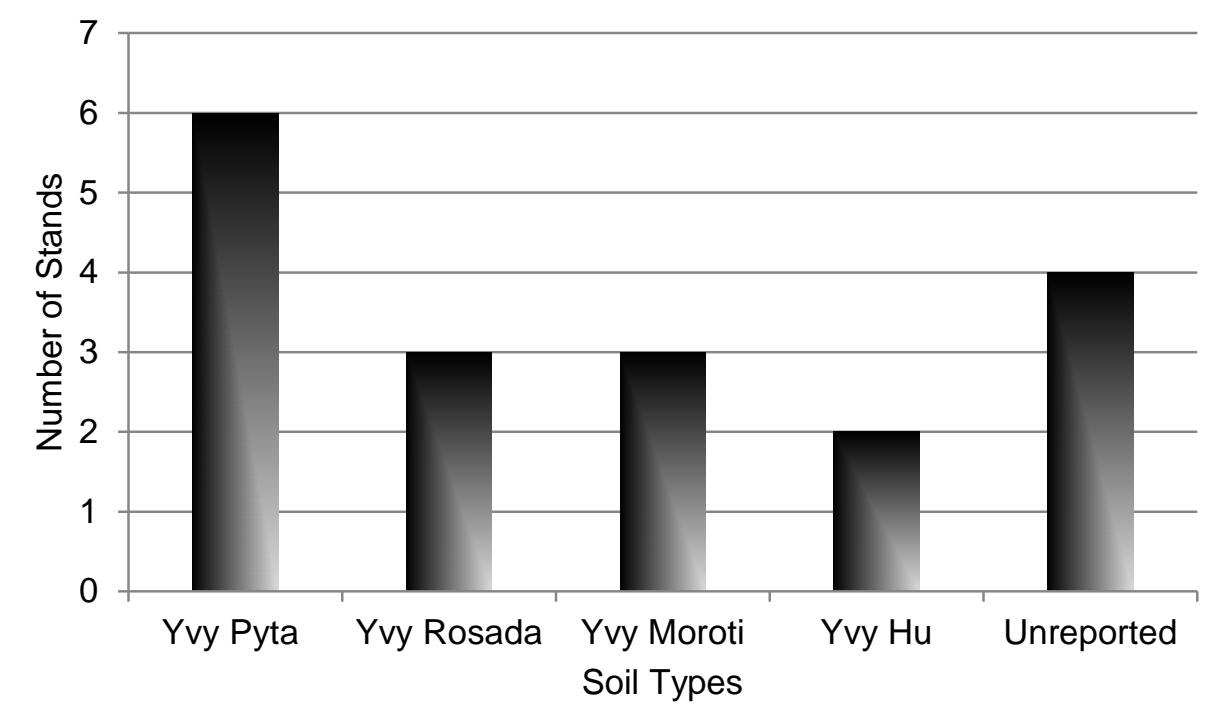

Figure 3.6 Number of stands by local soil types.

Topographic position was classified into three categories. Twelve stands were located on flat land, four stands were located on inclines with the land descending in all directions, and two stands were located in depressed areas on lower ground (Figure 3.7).

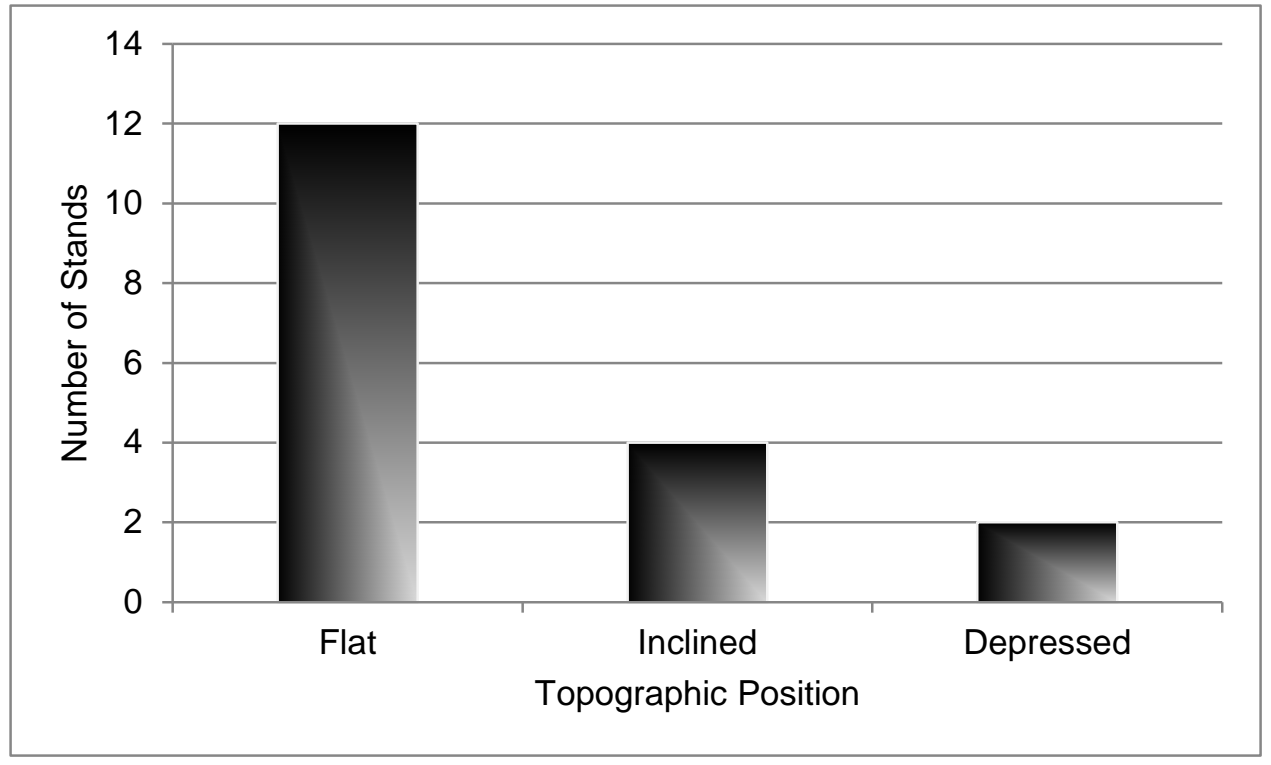

Figure 3.7 Number of stands by topographic position. 
Three different techniques were used for land preparation. The most common technique was mechanized preparation with a tractor (twelve stands) to both soften ground and clean weeds. Four stands were prepared manually with shovels. A hole was dug and ground softened to a width of 40 centimeters and a depth of 50 centimeters. The land immediately surrounding the holes was also cleaned using a hoe or a chemical herbicide (Mata J ujo) with properties similar to Round Up. The least common land preparation technique was the use of oxen and plow (two stands) to soften ground and uproot weeds (Figure 3.8).

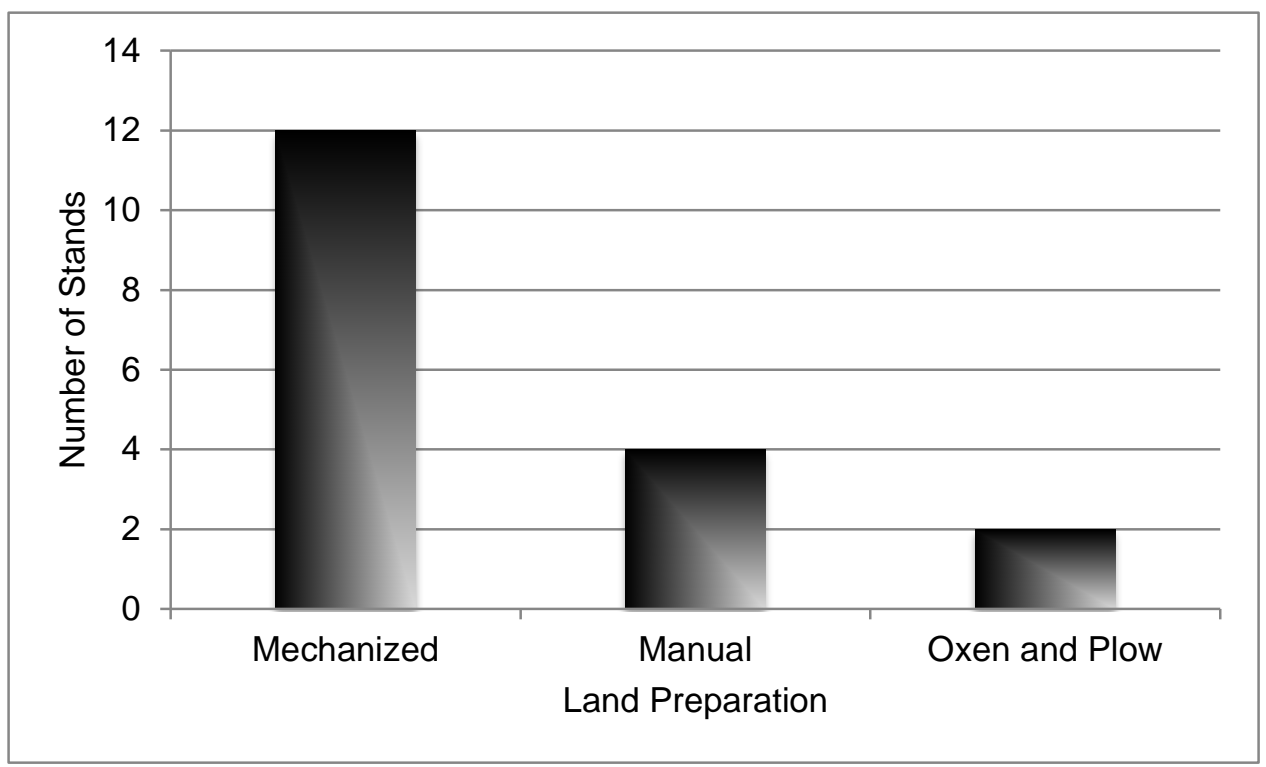

Figure 3.8 Number of stands by land preparation techniques.

All stands, with one exception were planted from seedlings grown at tree nurseries tended by forestry extension agents (Figure 3.9). One stand was planted from seedlings grown at a family tree nursery (Figure 3.10). Because this study did not include the youngest stands in the area (stands less than one year), the recent change in preference for smallholders to get seedlings from family tree nurseries was not captured. 


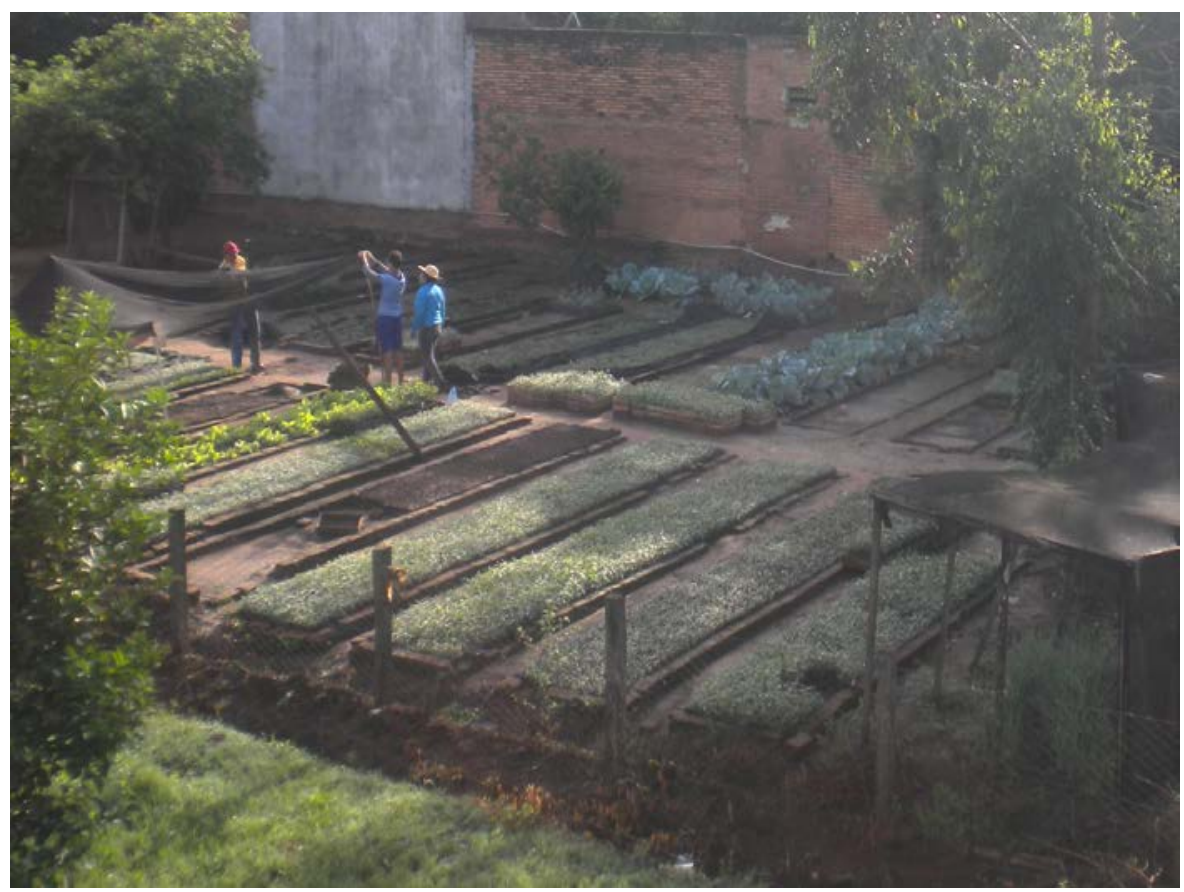

Figure 3.9 Tree nursery managed by forestry extension agents. Photo by B. Alloway.

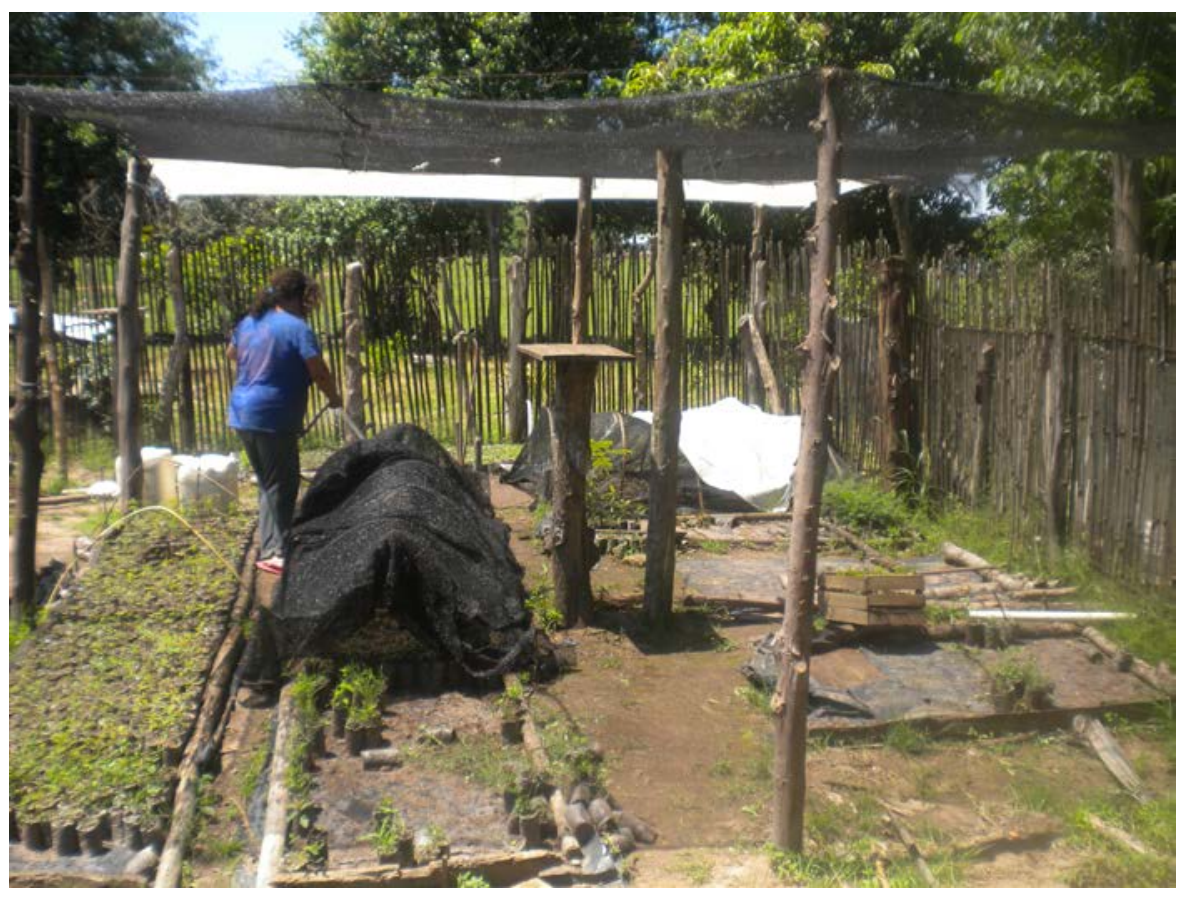

Figure 3.10 Family tree nursery specializing in E. grandis. Photo by B. Alloway. 
The vast majority of stands were planted in the late winter on the cusp of spring (twelve) with a few planted during spring (four) and one stand planted during the fall (Figure 3.11). No stands were planted during the hotter summer months.

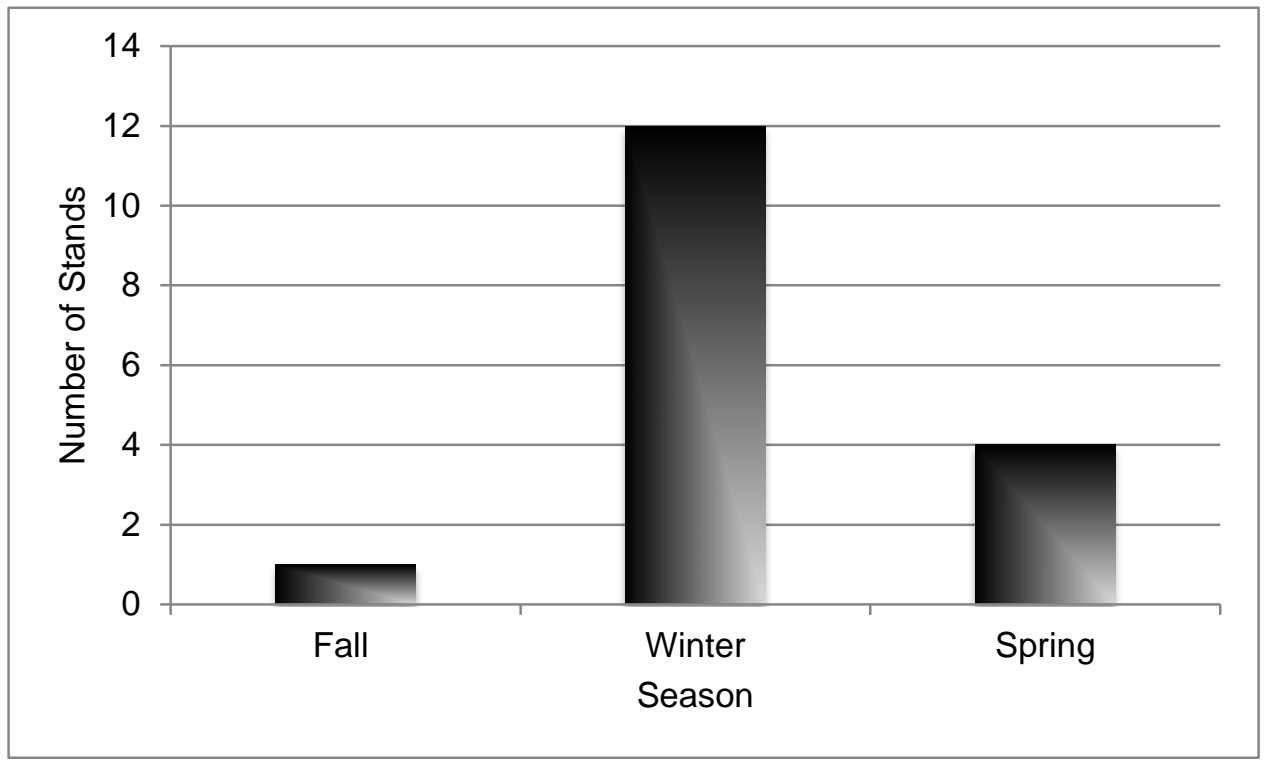

Figure 3.11 Number of stands by season of planting.

Before planting, four stands had natural fertilizers (cow manure) mixed into the soil. After planting, five stands used chemical fertilizers to stimulate growth. Fertilizers were inserted into the soil at the plant base, scattered on the soil surface, or sprayed on the leaves. Eight stands had neither chemical nor natural fertilizers added to the soil while one stand had both. Three stands had natural but not chemical fertilizers added as opposed to four stands that had chemical but not natural fertilizers added. Data were unreported for two stands (Figure 3.12). 


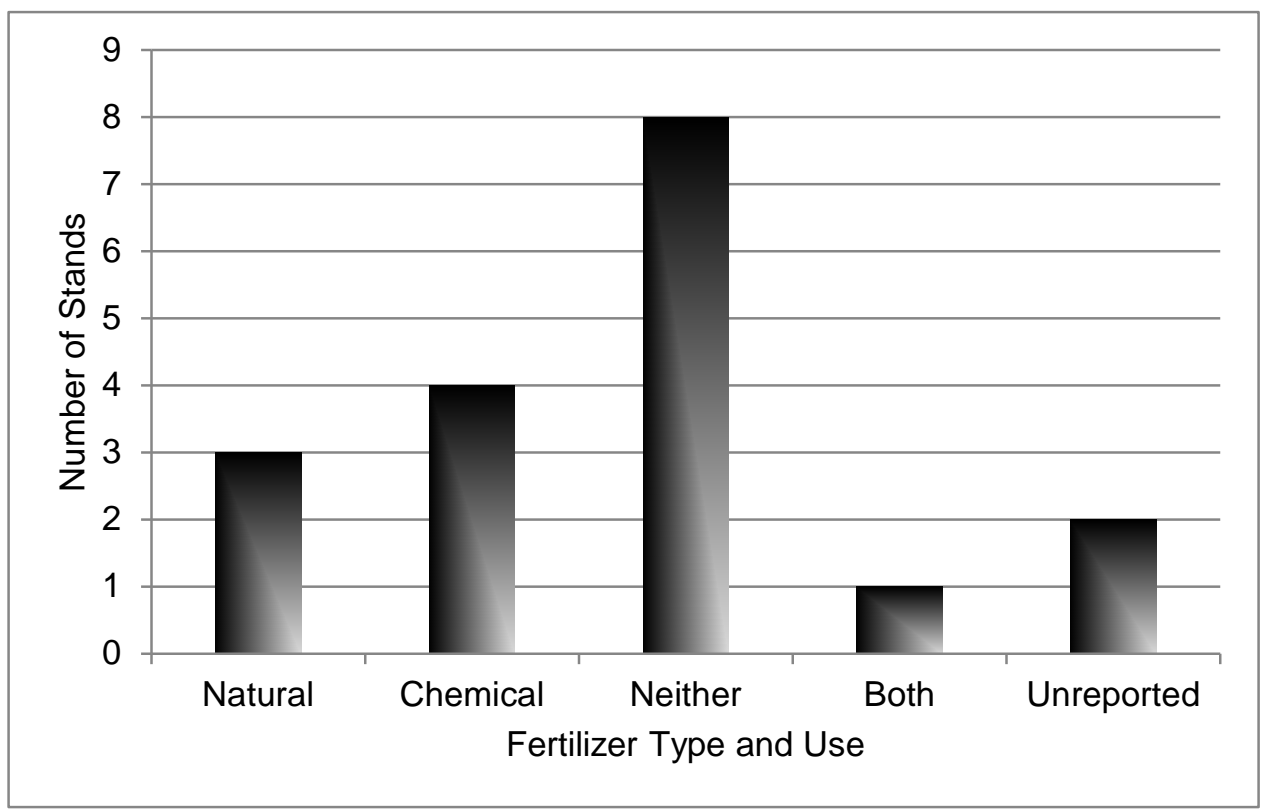

Figure 3.12 Number of stands by fertilizer type and use.

Pesticides were used on ten stands, in one instance as an insecticide, and for all other instances as herbicides to suppress weeds. Pesticides were used infrequently (one or two times a year) for the first one to two years. Pesticide use on E. grandis stands differs from pesticide use associated with cotton farming, because cotton, an annual cash crop, needs more frequent pesticide applications and applications occur each year. Six stands did not use pesticides and data were unavailable for two stands (Figure 3.13). 


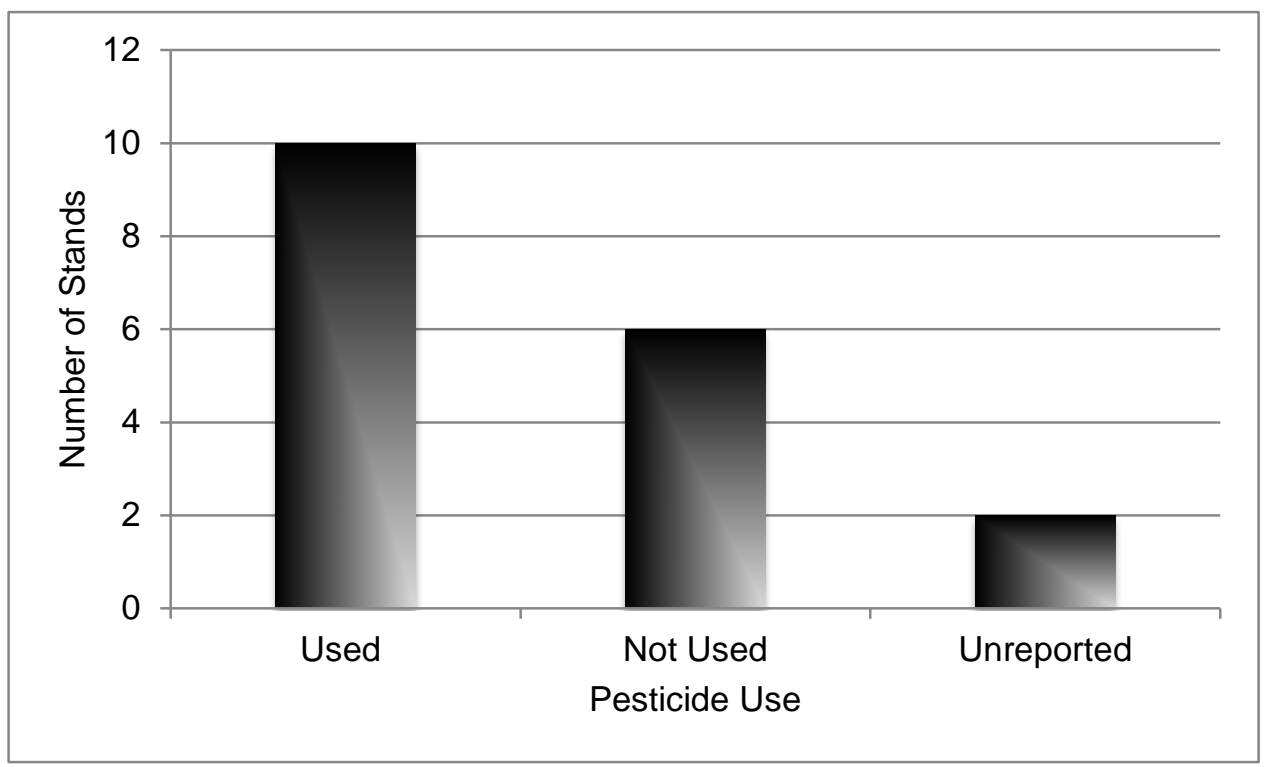

Figure 3.13 Number of stands by pesticide use.

Replanting for trees that did not establish occurred on twelve of the stands. Nine stands were replanted within three weeks of original planting and three stands were replanted within three months of original planting, leaving six stands that were never replanted (Figure 3.14).

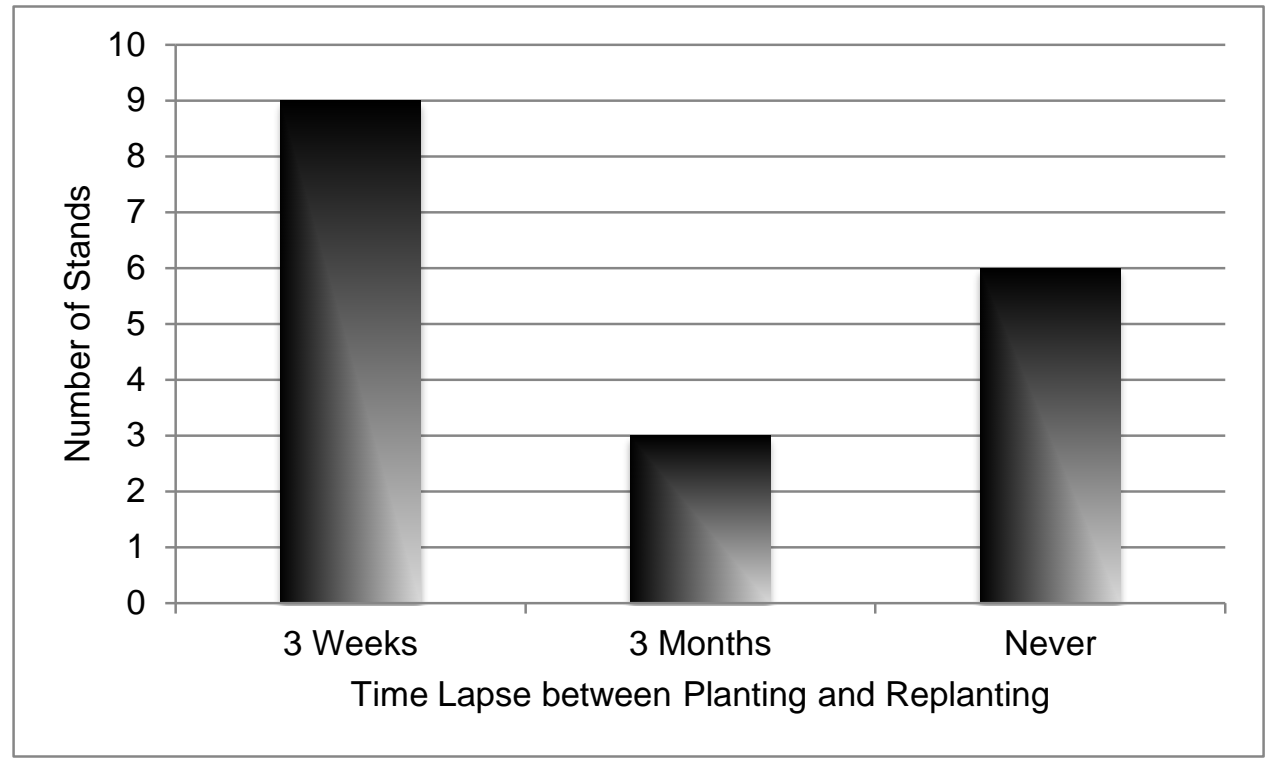

Figure 3.14 Number of stands and time lapse between original planting and replanting. 
Planting and replanting were non-mechanized activities requiring between two and five people. First, a grid of string was assembled to assure correct spacing. Second, teams of two planted trees and backfilled holes. Third, if rain was unlikely in the near forecast, a third person followed, watering seedlings (Figure 3.15).

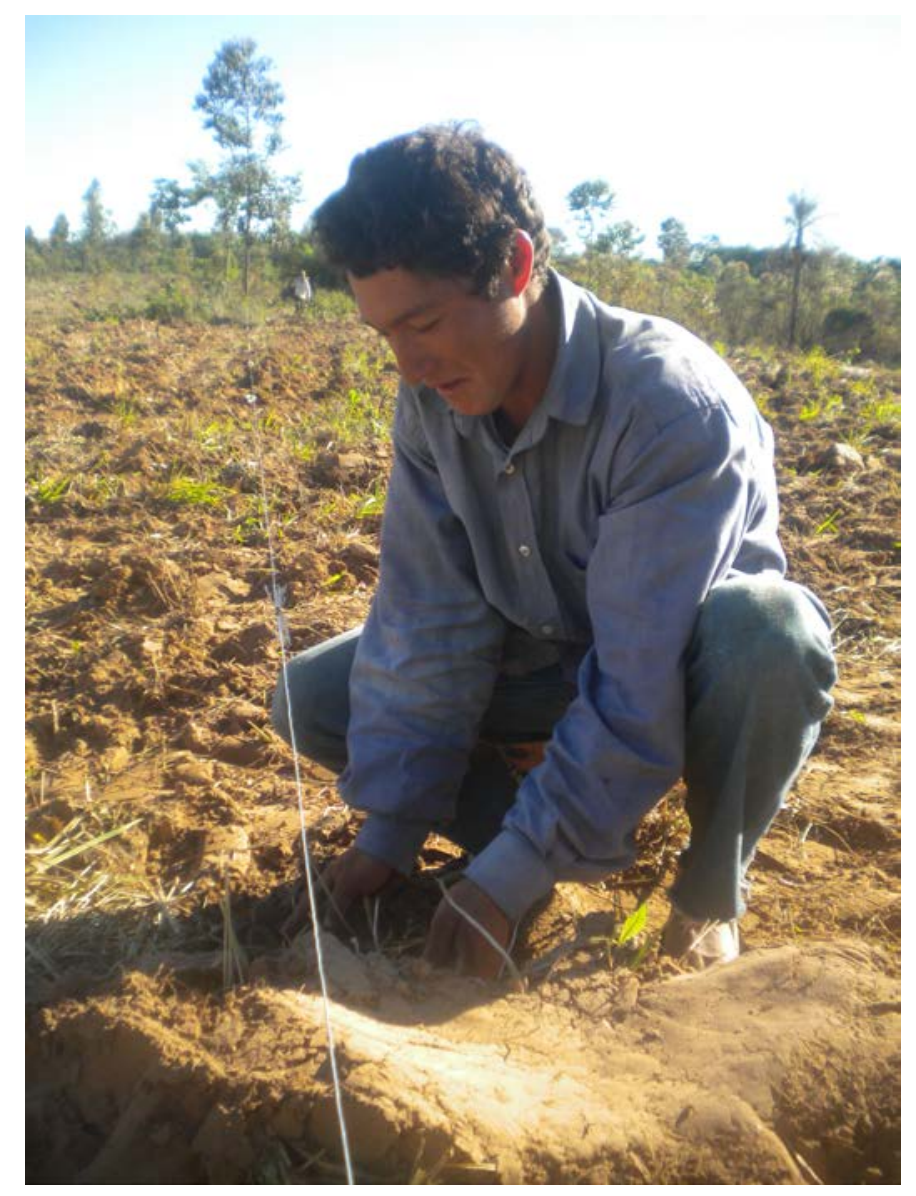

Figure 3.15 Replanting E. grandis after fire incident. Photo by B. Alloway.

Three stands were thinned. Two of the stands had been thinned in the year 2013, one stand at age five and the other at age six. The third stand was eight years old in 2013 and had been thinned three years previously at stand age 
five. Of the three other eight-year-old stands, one was harvested by a local lumber mill for the trees of best form (a little over half of the stand), and in the remaining two stands a few trees were harvested (no more than five trees per stand) by the owners for home use.

The vast majority of stand owners (fifteen) owned the plantation land. Three stand owners were lent the land by immediate family members.

Stands were managed by their owners, except for four stands managed by forestry extension agents for the first year(s), and another four stands managed by a neighbor, extended family member, or trusted associate (Figure 3.16).

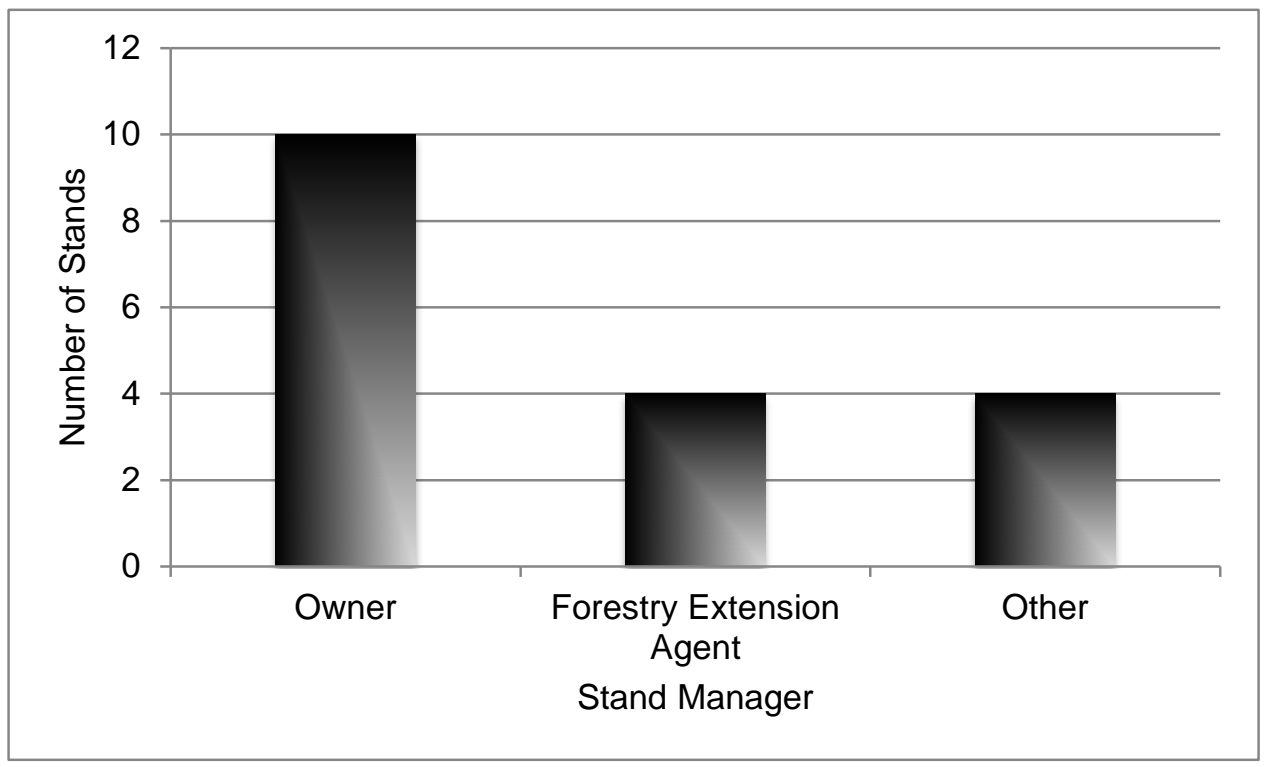

Figure 3.16 Number of stands by type of stand management.

Individual trees on fixed ten-meter by ten-meter sample plots were measured for tree grade. Eighty-five percent of all trees showed potential for achieving grade one status by the time of final harvest. Twelve percent showed potential for achieving grade two status by the time of final harvest. Three percent were of poor form and grade three quality (Table 3.4). The ninety-seven 
percent of trees with potential to achieve a tree grade of one or two does not account for natural tree mortality nor does it account for intermediate treatments when trees will be thinned out of the stands. However, if stands continue to be well pruned and are thinned appropriately, the majority of the trees in the stands will be of tree grade one at harvest.

Table 3.4 Percentage of sampled trees reported by tree grade potential.

\begin{tabular}{cc} 
Tree Grade Potential & Perecent of Sampled Trees \\
\hline 1 & $85 \%$ \\
2 & $12 \%$ \\
3 & $3 \%$ \\
\hline
\end{tabular}

\subsection{Data}

Individual trees on fixed ten-meter by ten-meter sample plots were measured for diameter at breast height (DBH) and total height. $\mathrm{DBH}$ and total height data from all sample plots on stands of the same age were averaged (Table 3.5). Minimum and maximum DBH and total height data were also recorded.

Table 3.5 Average DBH and total height for individual trees reported by stand age.

\begin{tabular}{|c|c|c|c|c|c|c|c|c|c|}
\hline \multirow{2}{*}{$\begin{array}{l}\text { Stand } \\
\text { Age }\end{array}$} & \multirow[b]{2}{*}{$\mathrm{N}$} & \multicolumn{4}{|c|}{ Diameter at Breast Height $(\mathrm{cm})$} & \multicolumn{4}{|c|}{ Total Height (m) } \\
\hline & & Mean & SD & Min & Max & Mean & SD & Min & Max \\
\hline 1 & 1 & 4.1 & 1.26 & 1 & 5.4 & 4.3 & 1.03 & 2 & 6 \\
\hline 2 & 5 & 8.9 & 3.07 & 1 & 18 & 9.9 & 2.80 & 2 & 16 \\
\hline 3 & 4 & 10.7 & 4.81 & 1 & 26 & 11.6 & 4.37 & 2 & 21 \\
\hline 4 & 1 & 11 & 5.20 & 3 & 20 & 11.5 & 4.96 & 3 & 19 \\
\hline 5 & 2 & 14.1 & 5.08 & 4 & 23 & 16.2 & 3.72 & 7 & 21 \\
\hline 6 & 1 & 22.5 & 2.99 & 20 & 29 & 24.1 & 2.43 & 19 & 27 \\
\hline 8 & 4 & 26.8 & 8.37 & 12 & 47 & 24.5 & 3.05 & 14 & 28 \\
\hline
\end{tabular}

Total height and DBH data collected in this study were used to calculate tree volume (Appendix B). Three individual tree volume equations developed for 
E. grandis were tested. Of these three equations Meskimen's (1978) volume equation for E. grandis was selected for use. Plot volumes were then computed, and stand volumes calculated from plot volumes. Calculated volumes were converted to metric units for further analysis.

$$
V=D^{2}(0.001818 H+0.0136)
$$

Where: $\quad \mathrm{V}=$ volume in cubic feet

$\mathrm{D}=$ breast height diameter in inches (outside bark)

$\mathrm{H}=$ total height in feet

This equation interprets the tree as a cylinder from ground level to $\mathrm{DBH}$ and as a cone from DBH to tip (Meskimen and Franklin, 1978).

\subsection{Statistical Analysis}

Statistical analyses were conducted on the data using the SAS (SAS Institute Inc., Cary, NC, USA) procedure PROC REG, creating a regression model with volume as the dependent variable and $\mathrm{age}^{2}$ as the independent variable. Ninety-five percent confidence limits and ninety-five percent prediction limits were calculated for the model. Linear regression was also used to test significance of dummy variables. Variables were considered significant at $\alpha<0.05$. Pearson's correlation coefficients for the volumes calculated with the three volume equations were computed with SAS procedure PROC CORR and considered significant at $\alpha<$ 0.05 . 


\section{Chapter 4 Results}

\subsection{Statistical Results}

Three volume equations, Meskimen (1978), Bredenkamp (1982), and Muhariwe's (1998) modified Schumaker and Hall (1933), were used to calculate tree volume from total height and DBH data collected in this study. For each tenmeter by ten-meter sample plot individual tree volumes were summed to produce plot volumes. Correlations between calculated plot volumes from these equations, tested using Pearson's correlation coefficient procedure in SAS, show a strong relationship between the three equations (Table 4.1).

Table 4.1 Pearson's correlation coefficient results.

\begin{tabular}{llll}
\hline & Bredenkamp & Meskimen & Muhairwe \\
Bredenkamp & 1.00000 & $\begin{array}{l}0.99904 \\
<0.0001\end{array}$ & $\begin{array}{l}0.99783 \\
<0.0001\end{array}$ \\
Meskimen & $\begin{array}{l}0.99904 \\
\text { <0.0001 }\end{array}$ & 1.00000 & 0.99852 \\
Muhairwe & 0.99783 & 0.99852 & $<0.0001$ \\
& $<0.0001$ & $<0.0001$ & 1.00000 \\
\hline
\end{tabular}

Equations with calculated plot volumes as dependent variables and $\operatorname{age}^{2}$ as independent variables were estimated with linear regression. Models created from volumes calculated from Bredenkamp's (1982) equation and Muhairwe's (1998) modified Schumaker and Hall (1933) equation resulted in $R^{2}$ values of 0.7226 and 0.7075 respectively. Different iterations of all formulas, including use with dummy variables, generated a range of similar $R^{2}$ values. Meskimen's (1978) equation was selected based upon the results from several early models. The regression 
model created from volumes calculated from Meskimen's (1978) equation

$\left(R^{2}=0.7119\right)$ is:

$$
\text { vol }=0.17635+0.03217^{*} \mathrm{Age}^{2}
$$

$(0.0206) \quad(<0.0001)$

Volumes calculated from Meskimen's (1978) equation were selected for all further statistical analyses.

Linear regression models were estimated with volume as the dependent variable and $\mathrm{age}^{2}$ and dummy variables as the independent variables. A separate linear regression model was estimated for each stand characteristic or silvicultural practice represented by a set of dummy variables (Table 4.2).

Table 4.2 Dummy variables tested for significance $(p<0.05)$.

Variable Variable Description

\begin{tabular}{|c|c|}
\hline $\begin{array}{l}\bar{A} \\
A=1 \\
A=0\end{array}$ & $\begin{array}{l}\text { Stand Ow nership } \\
\text { Tree owner owned land } \\
\text { Tree owner did not own land }\end{array}$ \\
\hline B & Stand Management \\
\hline$\overline{\mathrm{B}} 1$ & $\overline{\text { Owner managed stand }}$ \\
\hline B2 & Forestry Extension Agent (FEA) managed stand \\
\hline B3 & Stand managed by someone other than owner or FEA \\
\hline$\underline{\mathbf{C}}$ & Number of Stands on the Plantation \\
\hline$\overline{\mathrm{C}}=1$ & More than one stand on plantation \\
\hline$C=0$ & One stand on plantation \\
\hline D & Seedling Origin \\
\hline $\bar{D}=1$ & Seedlings originated in a family tree nursery \\
\hline $\mathrm{D}=0$ & Seedlings originated in a FEA tree nursery \\
\hline E & Season of Planting \\
\hline $\bar{E} 1$ & Fall \\
\hline E2 & Winter \\
\hline E3 & Spring \\
\hline
\end{tabular}

Table 4.2 is continued on the next page. 
Table 4.2 (cont.) Dummy variables tested for significance $(p<0.05)$

Variable

F

F1

F2

F3

$\underline{\mathbf{G}}$

$\mathrm{G}=1$

$\mathrm{G}=0$

$\underline{\mathbf{H}}$

$\mathrm{H}=1$

$\mathrm{H}=2$

1

$\mathrm{I}=1$

$\mathrm{I}=0$

$L$

$\mathrm{J} 1$

$\mathrm{J} 2$

J 3

K

$\mathrm{K}=1$

$\mathrm{K}=0$

느

L1

L2

L3

L4

M

M1

M2

M3

N

$\mathrm{N}=1$

$\mathrm{N}=0$ Variable Description

\section{Time Lapse between Planting and Replanting}

3 weeks

3 months

Never replanted

Chemical Fertilizer Use

Chemical fertilizer was used

Chemical fertilizer was not used

Natural Fertilizer Use

Natural fertilizer was used

Natural fertilizer was not used

Pesticide Use

Pesticide was used

Pesticide was not used

\section{Land Preparation}

Manual preparation with hoe

Preparation with ox and plow

Mechanical preparation with tractor

\section{Cleaning Practices}

Herbicides were used to clean

Manual cleaning with hoe was practiced

\section{Soil Type}

Red soil

Pink soil

White soil

Black soil

\section{Topographic Position}

Flat

Inclined

Depressed

Soil type and natural fertilizer use were the only variables found to significantly influence volume yield. 
Red $(p=0.0081)$ and Pink $(p=0.0028)$ soil types were more productive than White and Black soil types. The equation associated with soil type variability $\left(R^{2}=0.8352\right)$ is:

$$
\begin{aligned}
& \text { vol }_{\text {MES }}=-0.33482+0.04145 * a^{2} \mathrm{e}^{2}+0.44828 * \mathrm{~L} 1+0.54370 * \mathrm{~L} 2+0.24415 * \mathrm{~L} 3 \\
& \begin{array}{llll}
(0.0477) & (<0.0001) & (0.0081) & (0.0028)
\end{array}
\end{aligned}
$$

Black soil (L4) was omitted from the equation to eliminate a full rank matrix.

Smallholders identified Red soil and Pink soil as the most desirable soil types for farming in the study area. Smallholders stated that these two soil types were the most productive of the four local soil types for agricultural crop cultivation. Red and Pink soils were known locally for their high clay content, high nutrient content, and ability to retain these nutrients. They were also known for their drainage qualities. Red and Pink soils were known to drain excess moisture; they were not muddy, like Black soil. Red and Pink soils were known to retain soil moisture; they were not sandy like White soil. The characteristics associated with Red and Pink soils would explain the significance of variables associated with soil type.

Stands that had natural fertilizer applications of dried cow manure during land preparation or planting $(\mathrm{p}=0.0486)$ were more productive than stands that did not engage in this practice. The equation associated with natural fertilizer use variability $\left(R^{2}=0.8487\right)$ is:

$$
\begin{aligned}
& \text { vol }_{\text {MES }}=0.19375+0.02489 * \text { age }^{2}+0.25240 * \mathrm{H} \\
& \begin{array}{lll}
(0.0059) & (<0.0001) & (0.0486)
\end{array}
\end{aligned}
$$

Natural fertilizers, high in organic matter, nitrogen and other useful nutrients, break down and release these nutrients slowly into the soils. The trees 
growing on stands with natural fertilizers responded positively to these added resources as illustrated by the significance of this variable.

\subsection{Result Comparisons}

The regression equation: $\mathrm{vol}=0.17635+0.03217^{*} \mathrm{Age}^{2}$

$(0.0206) \quad(<0.0001)$

is a predicted volume model estimated from plot volume data collected in this

study (Figure 4.1). Though plot volumes were used to estimate the above equation, volumes were then expanded to cubic meters per hectare in order to make comparisons to other growth and yield studies. All studies used for comparisons were conducted in subtropical climates on E. grandis plantations of similar stocking densities to those sampled in this study unless otherwise noted.

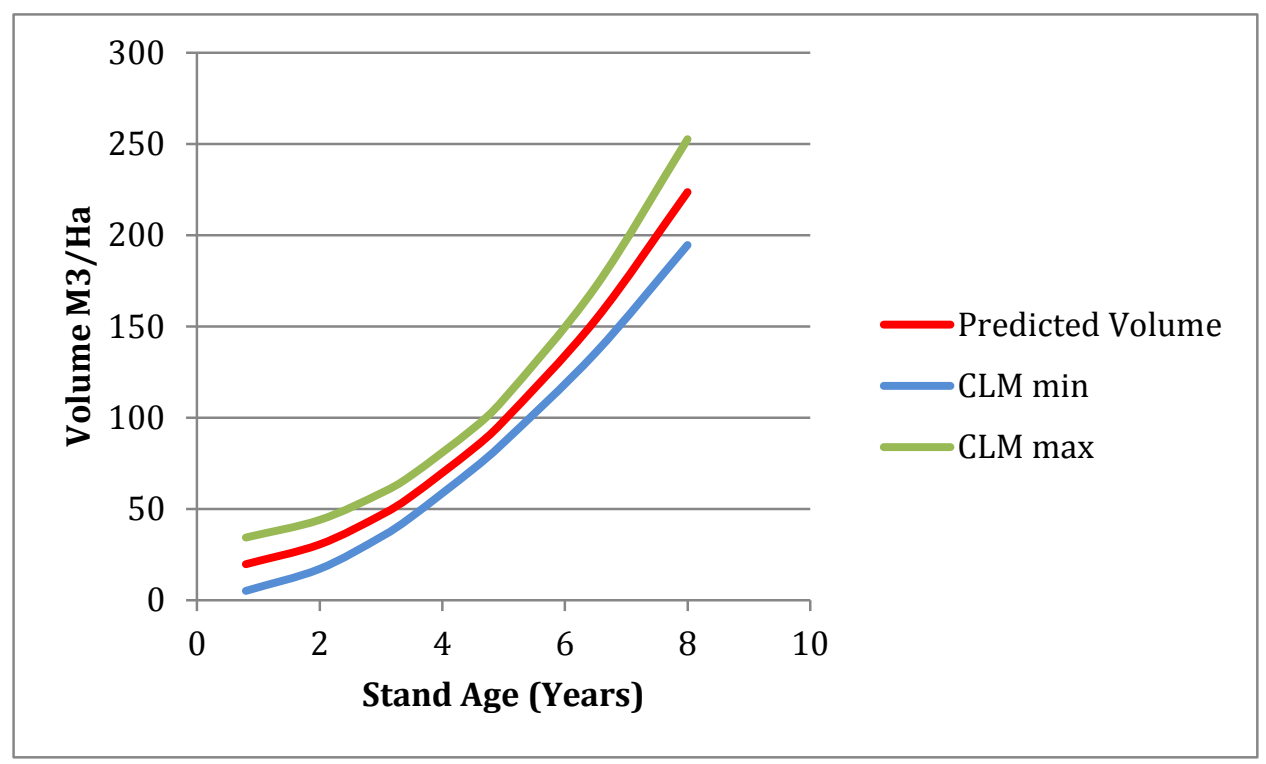

Figure 4.1 Predicted volumes and 95\% confidence limits of the mean for $\mathrm{E}$. grandis in the study area. Volumes and confidence limits were calculated using the equation $\mathrm{V}=0.1763+0.03217^{*}$ age $^{2}$. 
Volume yields in the study area were similar to volume yields of a fair site in South Africa (Figure 4.2) (FAO, 1981). The study conducted in South Africa measured volumes of E. grandis on unthinned stands with a stocking level of 1,100 trees per hectare at ages between three and nine years on six different site indices. Site indices were not specified but generalized to good, fair and poor. The estimated volumes reported in the study assume full-stocking levels at all ages. The original author, Van Laar, suggests reducing volume levels by ten percent to allow for realistic, less than full, stocking values (FAO, 1981).

Therefore, the volumes reported in Figure 4.2 have been reduced by ten percent from their original values.

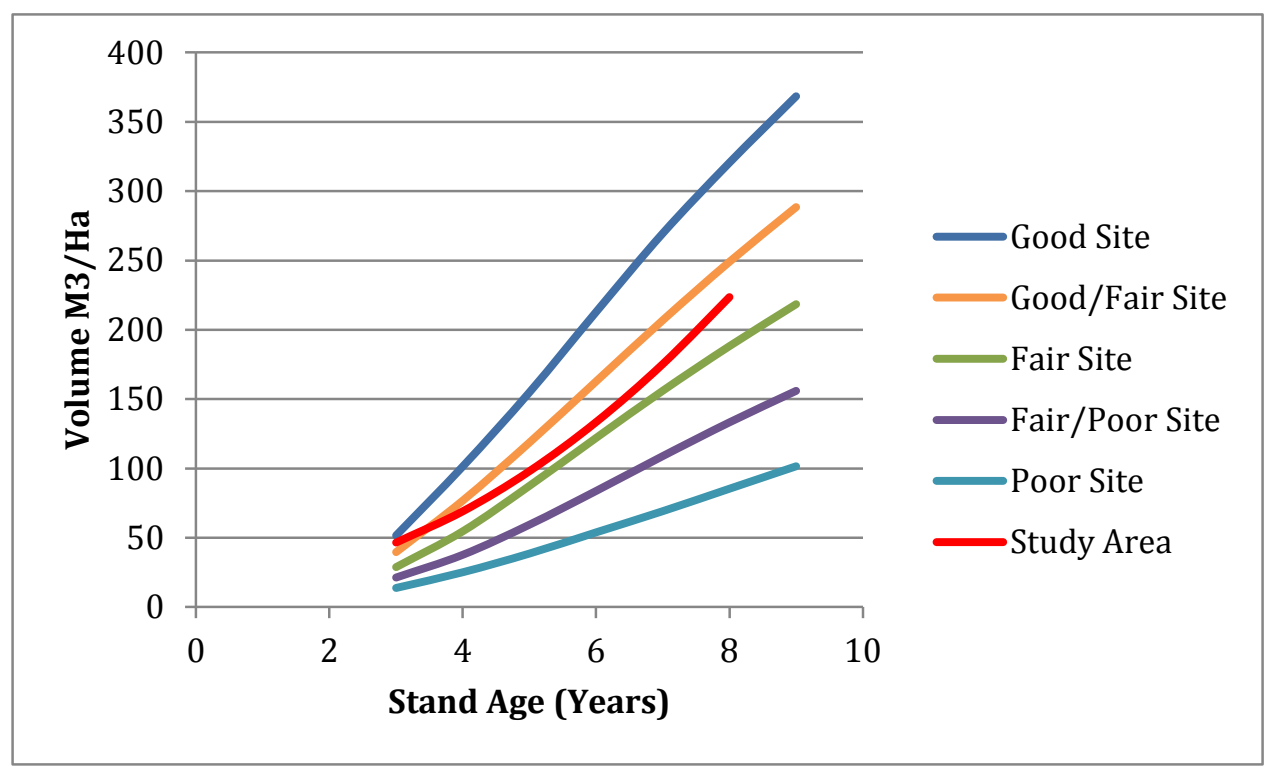

Figure 4.2 A comparison of volume yields from the study area and trials in South Africa. South African volumes reduced by ten percent.

Volume yields were higher in the study area than volume yields on moderately fertile sites in Zimbabwe. However, volume yields were lower in the study area than volume yields on fertile sites in Zimbabwe (Figure 4.3). The study in Zimbabwe measured E. grandis unthinned stands stocked at 1,111 trees per 
hectare. The study defined a site index (at age seven) of twenty-six meters as fertile and a site index of nineteen as moderately fertile (Mabvurira and Miina, 2002).

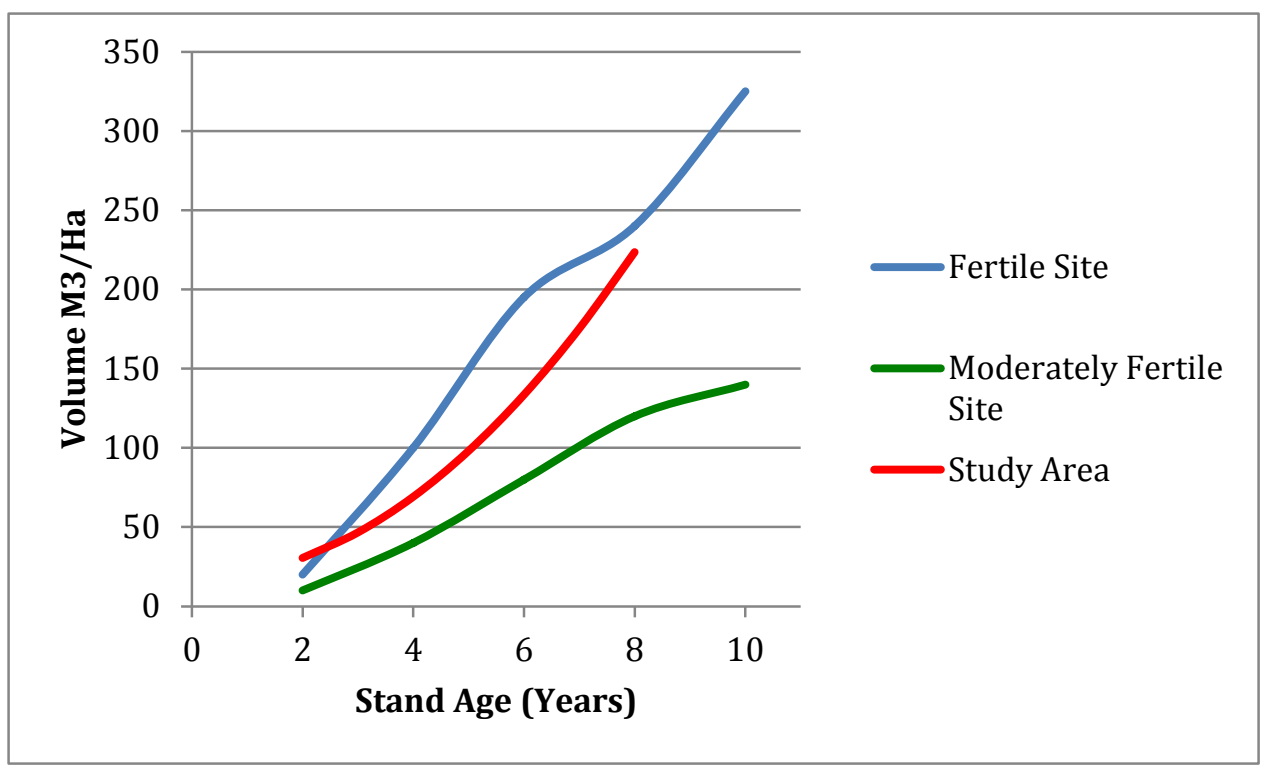

Figure 4.3 A comparison of volume yields from the study area to trials in Zimbabwe.

In the study area volume yields were lower than volume yields measured for spacing trials in Hawaii (Walters, 1980). Sample plots used for comparison from the Hawaii study were E. saligna species, unthinned at a stocking of 1,100 trees per hectare. Measurements were taken at ages one, two, five and ten years (Figure 4.4). E. saligna and E. grandis are closely related species with comparable characteristics. The differences between these species should not result in dramatic differences of volume yields. However, a more favorable climate for tree growth in Hawaii could explain the higher volume yields recorded in the trials. Annual rainfall in the Hawaii study area was 3,800 millimeters evenly distributed throughout the year and soils were silty clays deep and well drained (Walters, 
1980). These characteristics are more favorable for tree growth than the characteristics in this study area.

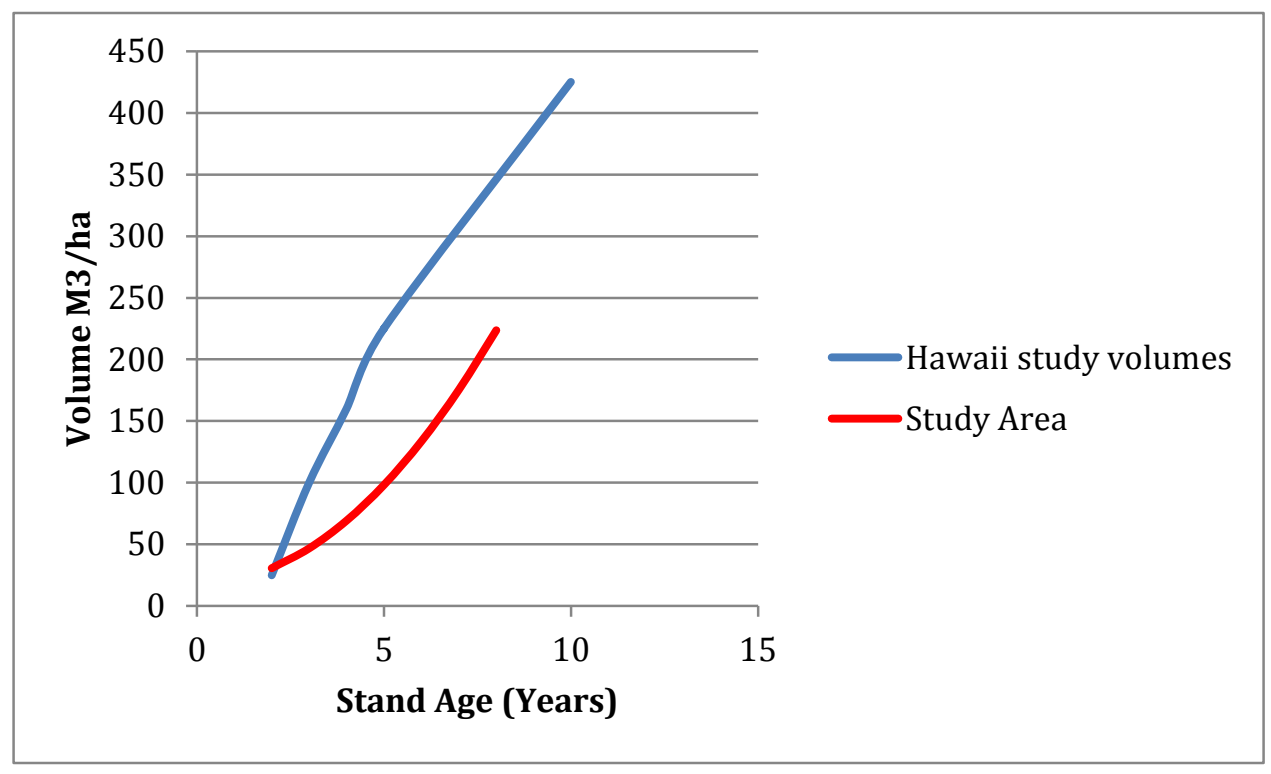

Figure 4.4 A comparison of volume yields from the study area and trials in Hawaii.

In the study area volume yields were lower than volume yields measured at Aracruz Cellulose S.A. in Brazil (Figure 4.5). The stands measured in Brazil were E. grandis clones (clone fifteen and clone twenty-two) planted at 1,111 trees per hectare in an experimental catchment area (Almeida et al., 2004). The hybridized clones were bred for rapid growth, and thus should produce more volume than non-hybridized E. grandis genotypes used in this study. 


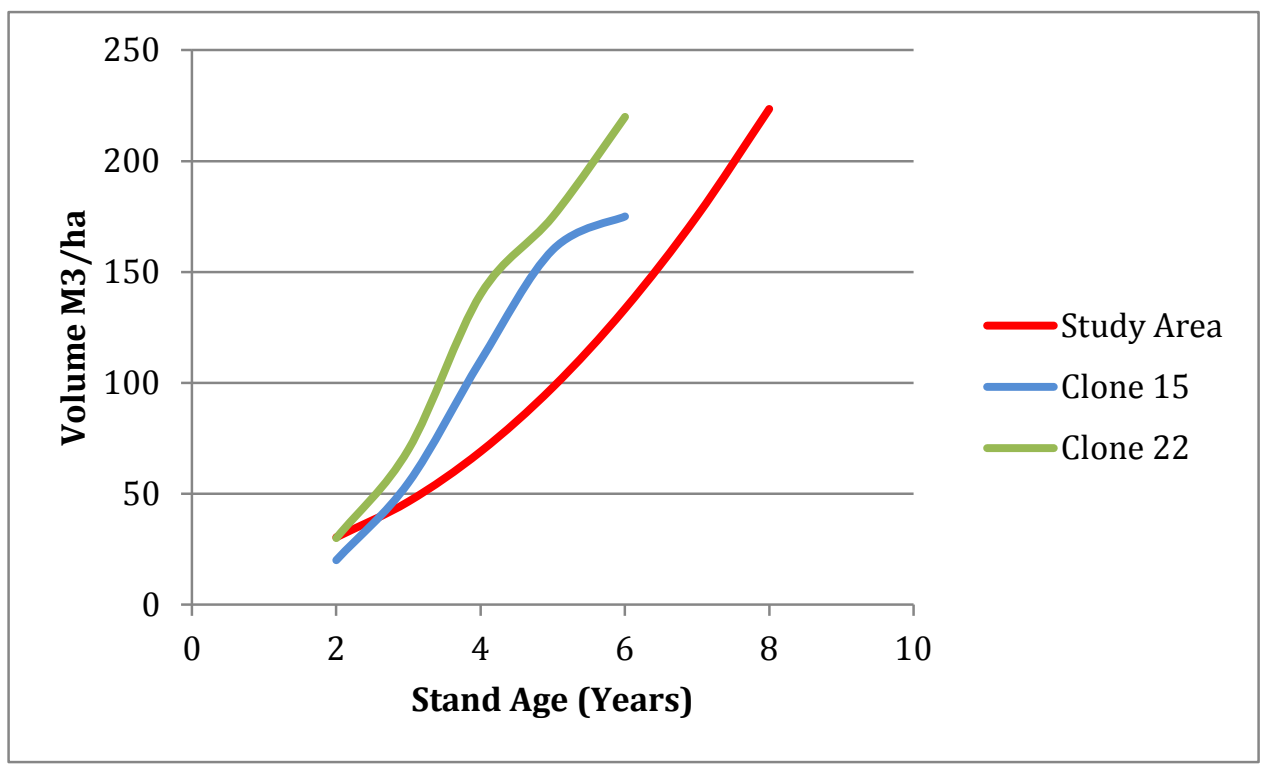

Figure 4.5 A comparison of volume yields from the study area and trials at Aracruz Cellulose S.A. in Brazil. 


\section{Chapter 5 Discussion}

The comparisons between volume yields in the study area to volume yields of South Africa and Zimbabwe studies on fair sites suggest that smallholders in Pindoyu are engaging in silviculture practices resulting in reasonable volume yields. These three studies measured volumes on stands of E. grandis of similar stocking levels and climates, and all trials on fair sites reported similar volume yields (Mbavurira and Miina, 2002; FAO, 1981). This is impressive when considering that forestry professionals were planting and tending to the study trials in South Africa and Zimbabwe. Smallholders in Pindoyu are producing similar volumes from their E. grandis stands, suggesting that they are following reasonable silviculture practices. Through personal observations it was clear that many stands were pruned to effective heights leaving a live crown large enough to support tree growth, yet small enough to discourage branch growth. Stands had either reached crown closure and had few weeds present in the understory or younger stands were cleaned up to three times a year for the first few years to reduce competition. Rows were straight and well spaced and trees had good form (Figure 5.1). However, pre-commercial thinning was not frequently practiced resulting in smaller diameter trees competing with one another for resources. 


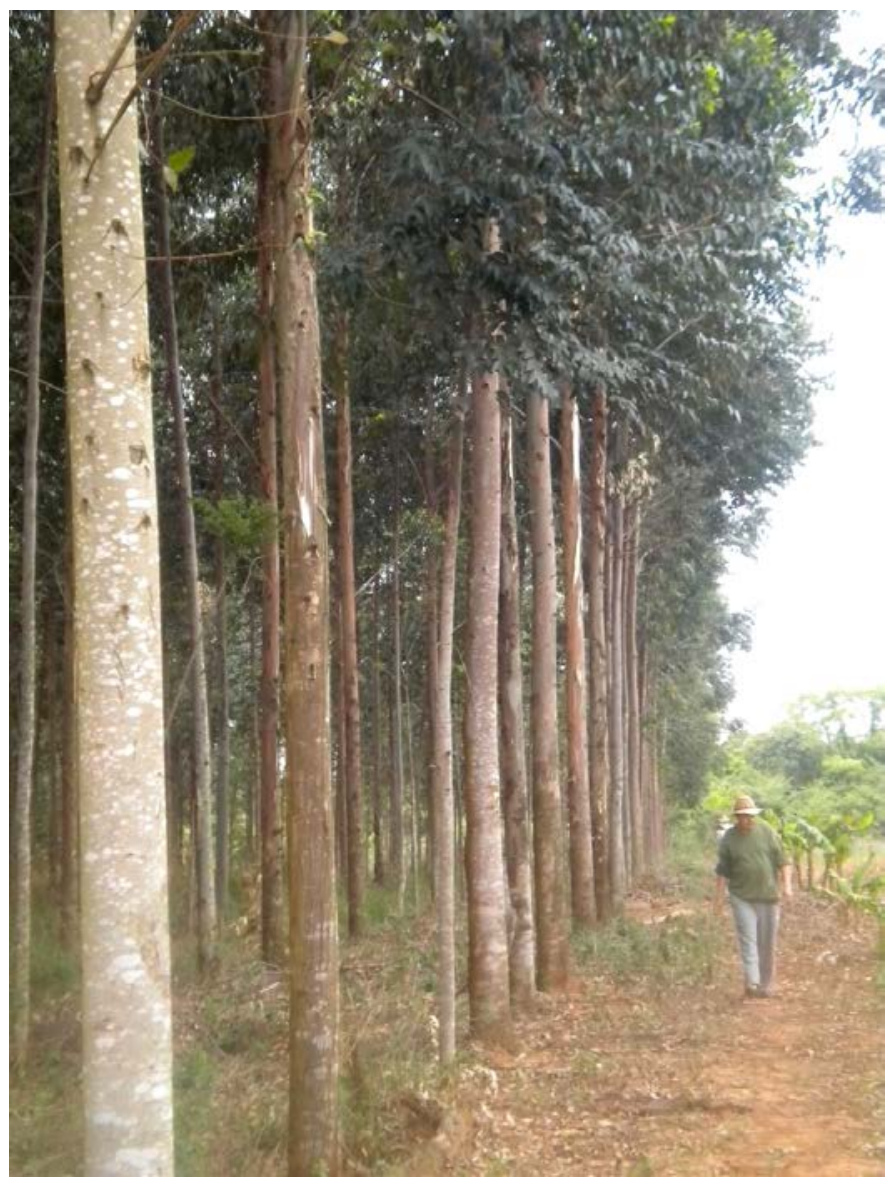

Figure 5.1 Five-year-old E. grandis stand in Pindoyu. Photo by B. Alloway.

Comparing volume yields in the study area to those of Aracruz Cellulose S.A. suggests that smallholders could improve volume production through investments in hybridized or cloned eucalyptus seedlings (Almeida, 2004). Pomera Maderas, the largest and most technologically advanced eucalyptus corporation in close proximity to the study area, sells seeds collected from parent trees of the highest quality to local tree nurseries and to forestry extension agents. The seedlings planted on the stands measured for this study originated from tree nurseries that purchase seeds from Pomera Maderas. These seedlings grew into trees of good form and resulted in reasonable volume production. If 
hybridized and cloned seedlings were planted instead, trees of better form that produce higher volumes, would be expected.

In Caazapá, the growth in the forestry industry over the past ten years created opportunities for smallholders to buy hybrid and cloned seedlings. These advanced seedlings are sold at higher costs than non-hybridized seedlings. In 2013 cloned eucalyptus seedlings were available, being shipped in from Plantec Vivero Forestal (a cloned nursery) located 123 kilometers north of the study area, and available for purchase at local tree nurseries and from forestry extension agents. Forestry extension agents themselves, had switched over to planting cloned eucalyptus hybrid plantations on their own or rented lands.

The expanding industry, along with creating opportunities to buy higher quality seedlings at higher costs, created opportunities to buy lower quality seedlings at lower costs. Innovative families began family tree nurseries in hopes of financial gain in the newest market. Seedlings grown in family tree nurseries were of poorer quality because parent trees were determined by the proximity and accessibility of tree seeds verses genotype. The concern is that the average smallholder will be attracted to the lower cost per seedling that family tree nurseries can offer and will not give enough consideration to the quality of the seedling.

Studies on volume yields and local observations, comparing different stands of different seedling genotypes, suggest planting better quality seedlings will result in higher volume production. E. grandis stands will coppice in the future, the first seedlings planted will be the genotype of future generations. In 2013 a variety of seedling types and qualities were available in the study area. The decisions smallholders make regarding what type of seedlings they will plant will potentially affect the stand for decades. Smallholders, when purchasing 
seedlings for planting, will need to make wise choices concerning the future of their eucalyptus stands while also weighing the importance of present financial savings.

The studies conducted in Hawaii, South Africa and Zimbabwe all support that higher quality sites produce higher volume yields (Mabvurira and Miina, 2002; FAO, 1981; Walters, 1980). Volume yields in the Pindoyu study area were estimated somewhere in between volume yields on sites of best and poorest site indices suggesting the overall quality of sites in the study area were fair.

Comparing volume yields in the study area to E. grandis yields on many different site indices, suggests the smallholder could increase volume production by either planting E. grandis on more fertile sites or investing in soil improvement strategies.

The results estimated from the linear regression models associated with natural fertilizer use and soil quality support this theory. Stands with more fertile soils and stands that had natural fertilizer applied produced higher volume yields than those that did not. However, smallholders in the study area rely on their lands to grow food crops and graze animals. The most fertile sites are commonly reserved for growing staple crops intended for human consumption, as animal feed, or for sale. Though site quality may influence volume yields it is not realistic for smallholders to dedicate the most fertile lands for tree production versus crop production.

Every E. grandis woodlot in Pindoyu could be improved. For example, one stand may have been cleaned but not pruned, or another stand may have been pruned but not thinned. However, given smallholder resources and land use restrictions, smallholders are making decent silviculture decisions and following recommended forestry practices (Whitesell et. al. 1992; SPGS, undated). They 
are planting at recommended spacings, replanting trees that do not establish, practicing commercial thinning, cleaning and pruning stands, and using fertilizers or planting on generally fertile sites. These practices seem to result in reasonable volume production.

It is likely that smallholders in the study area are engaging in silviculture practices because of the education outreach programs offered by the national forest service and the economic rewards the local market offers for larger diameter trees of good form. The local standards for tree grade are determined by diameter, straightness of the bole, and amount of branches on the first eleven meters. A tree grade of one signifies the bole will have numerous straight and branch free sections of two and a half meters with a twenty-one centimeter diameter at eleven meters. A tree grade of three signifies the bole is of poor form, has excessive branching or is less than nineteen centimeters at DBH. A tree grade of two lies in between these two extremes. The local market will not buy trees of grade three for saw log production. These trees can only be sold for chip/biomass production which are of less economic value. Trees of grade one and two can be sold for saw log production. A tree grade of one is worth three times more money than a tree grade of two and six times more money than a tree grade of three (Table 5.1). 
Table 5.1 Local tree grade and associated price values for E. grandis

\begin{tabular}{clcc} 
Tree Grade & \multicolumn{1}{c}{ Description } & $\begin{array}{c}\text { Value } \\
\text { Local Currency } \\
\text { (Guaranies) }\end{array}$ & $\begin{array}{c}\text { Value } \\
\text { (US Dollars) }\end{array}$ \\
\hline 1 & $\begin{array}{l}21 \mathrm{~cm} \text { diameter at } 11 \mathrm{~m} \\
\text { First } 11 \mathrm{~m} \text { straight and } \\
\text { branch free }\end{array}$ & 523,000 & 119 \\
2 & $\begin{array}{l}19 \mathrm{~cm} \text { at DBH. First } 11 \mathrm{~m} \\
\text { relatively straight and } \\
\text { few branches } \\
\end{array}$ & 163,000 & 37 \\
\hline & $\begin{array}{l}<19 \mathrm{~cm} \text { at DBH } \\
\text { poor form }\end{array}$ & $<90,000$ & $<20$ \\
\hline
\end{tabular}

It is financially wise for smallholders to engage in silviculture practices that produce saw log quality trees because the local market rewards those that produce large trees of good form. Smallholders were observed planting seedlings of good genotype, and cleaning and pruning their stands because smallholders expected to profit from these practices.

The current situation in the study area is somewhat unique. Smallholders have an opportunity many others in similar predicaments do not. In developing countries smallholders are not always presented with financial incentives from local markets to practice good forestry. In Isangati Tanzania smallholders did not receive payments based on exact tree size, volume or form and thus it was more profitable for smallholders to sell smaller trees on shorter rotations as the smallholders would net the same profit for trees harvested after eight or fifteen years (Francis, 2012). 


\section{Chapter 6 Conclusion}

E. grandis smallholders in Pindoyu are engaging in silvicultural practices that produce reasonable volume yields and trees of good form. This suggests smallholders are educated and meeting regional forestry practice standards. To help smallholders improve yields, forestry education efforts should be directed towards improving seedling quality and site fertility. In the study area encouraging smallholders to plant better seedlings, add natural fertilizers to soils, and plant on sites of Red or Pink soil types will have a positive effect on volume yields.

Smallholders are practicing forestry techniques to produce saw log quality trees and markets financially reward these efforts. However, there is no direct connection between the smallholder and the market. Smallholders do not have the necessary equipment to harvest their own stands and transport timber to the wood processors. Wood processors do not have the time or interest to travel the countryside and find mature stands. That said, wood processors are able and willing to harvest and transport timber from stands as small as a fourth hectare in size. They are willing to pay market value (minus cost of harvest and transport) to the smallholder, but wood processors must be requested to do so. Smallholders do not travel nor know of these opportunities. Instead, a third party, a middleman, will travel the countryside, locate mature stands, and harvest and transport timber from these smallholder E. grandis stands. A middleman will receive market value for the timber they deliver but they pay the smallholder only one-fifth the value of the standing trees. The limited options available for farmers to sell trees, a need for cash in hand, and the uncertainty of when the opportunity to sell will come again, all encourage smallholders to sell their stands to 
middlemen at a low price.

If smallholders are to view E. grandis woodlots as good financial investments development efforts should be targeted to connect the smallholder to the wood processor. Connecting these two parties and eliminating the middleman will have a significant impact on smallholder profits.

When the day comes that smallholders plant quality seedling genotypes, and sell timber directly on the local market, the smallholder who plants eucalyptus in eastern Paraguay will realize the full value of small-scale forestry. 


\section{Literature Cited}

Almeida AC, Landsberg JJ, Sands PJ (2004). Parameterisation of 3-PG model for fast-growing Eucalyptus grandis plantations. J Forest Ecology and Management. 193; 179- 195.

Anon., (2006). Alfredo Stroessner. The Economist Newspaper Limited. http://www.economist.com/node/7826946; last accessed Feb 15, 2014.

Atlas Censal del Paraguay (2002). Direccion General de Estadistical encuestas y censos Paraguay. http: // www.dgeec.gov.py/Publicaciones/Biblioteca/Atlas\% 20Censal\% 20del\% 20 Paraguay/9\%20Atlas\% 20Caazapa\%20censo.pdf; last accessed Feb 15, 2014.

Brawner JT, Elizual JF (undated). Eucalyptus grandis breeding populations managed for solid wood production in Paraguay and Northern Argentina. Ensis Genetics, Cooroy Australia.

Bredenkamp BV, Loveday NC (1984). Volume equations for diameter measurements in millimeters. South African Forestry J. 130(1);40.

CIA (2013). The World Factbook. https://www.cia.gov/library/publications/the-world-factbook/geos/pa.html; last accessed Feb 15, 2014.

Doughty RW (2000). The Eucalyptus: a natural and commercial history of the gum tree. Johns Hopkins University Press., Maryland, pp. 179.

Evans J, Turnbull JW (2004). Plantation forestry in the tropics. Oxford University Press Inc., New York, pp. 394.

FAO (1981). Eucalyptus for planting. Food and agriculture Organiztion of the United Nations. FAO forestry Series11;547-549. Rome, Italy.

FAO (2006). Country pasture/forage resource profiles. http://www.fao.org/ag/AGP/AGPC/doc/Counprof/Paraguay/paraguay.htm; last accessed Feb 15, 2014.

Fletschner DK, Zepeda L (2002). Efficiency of small landholders in eastern Paraguay. J. Agricultural Resource Economics. 27(2);554-572.

Francis PD (2012). Small-scale timber stand management techniques: A case study of woodlots in Isangati, Tanzania. Unpublished thesis. Michigan Technological University, Michigan.

Frey GE (2007). Timber investment returns in Paraguay. Unpublished report. World Bank, Washington D.C.

Kottek M, Greiser J, Beck C, Rudolf B, Rubel F (2006). World Map of KoppenGeiger Climate Classification. Meteorol Z. 15;259-263. 
Mabvurira D, Miina J (2002). Individual tree growth and mortality models for Eucalyptus grandis (Hill) Maiden plantations in Zimbabwe. J Forest Ecology and Management. 161;231-245.

Meskimen G, Franklin EC (1978). Spacing Eucalyptus grandis in southern Floridaa question of merchantable versus total volume. Southern J. of applied forestry. 2(1);3-5.

Muhairwe CK (1999). Taper equations for Eucalyptus pilularis and Eucalyptus grandis for the north coast in New South Wales, Australia. J Forest Ecology and Management. 113;251-269.

Schumacher FX, Hall F (1933). Logarithmic expression of timber-tree volume. J Agric. Res. 47; 719-734.

SAS Institute Inc. (2008). SAS®9.2. Cary, NC, USA

SPGS (undated). Growing eucalypts for timber, poles and fuelwood. SPGS Plantation Guidelines Nos. 9 and 10 V2.

http://www.sawlog.ug/index. php/guide-lines/by-chapter.html; last accessed Feb 12, 2014.

Stadius E (2012). Land reform issues intensify as Paraguay enters into a political crisis. Council on Hemishperic Affairs.

http: // www.coha.org/land-reform-issues-intensify-as-paraguay-enters-into-apolitical-crisis; last accessed Feb 15, 2014.

Walters G (1980). Saligna eucalyptus growth in a 15-year-old spacing study in Hawaii. Pacific Southwest Forest and Range Exp. Stn., Forest Serv., U.S. Dep. Agic. Berkely California. Res. Paper PSW-151:6.

Whitesell CD, DeBell DS, Schubert TH, Strand RF Crabb, TB (1992). Short-rotation management of Eucalyptus: guidelines for plantations in Hawaii. Gen. Tech. Rep. PSW-GTR-137. Albany, CA: Pacific Southwest Research Station, Forest Service, U.S. Dep. of Agric. pp.30. 


\section{Appendix A}

\section{Stand Characteristics and Silvicultural Practices Data}

Numerically coded stand characteristics and silvicultural practices data

\begin{tabular}{|c|c|c|c|c|c|c|c|c|c|c|c|c|c|c|c|c|c|c|}
\hline 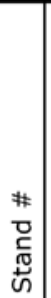 & 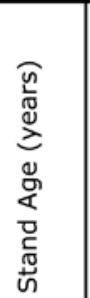 & 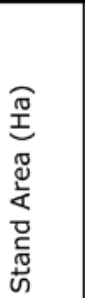 & 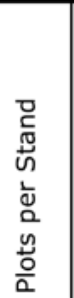 & 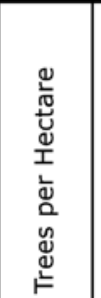 & 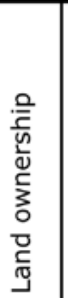 & 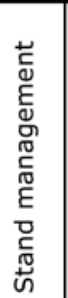 & 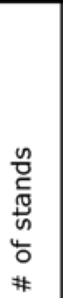 & 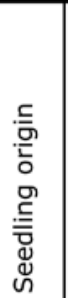 & 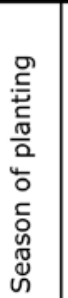 & 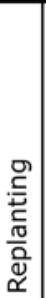 & 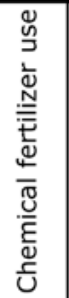 & 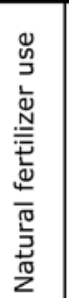 & 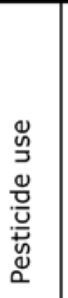 & 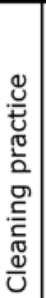 & 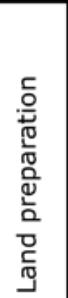 & 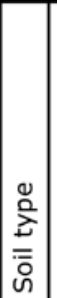 & 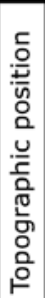 & 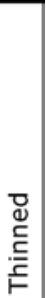 \\
\hline 1 & 1 & 1 & 2 & \begin{tabular}{|l|}
1,111 \\
\end{tabular} & 2 & 1 & 1 & 1 & 2 & 2 & 1 & 2 & 1 & 2 & 1 & \begin{tabular}{|l|}
1 \\
\end{tabular} & 3 & 2 \\
\hline 2 & 2 & 0.75 & 2 & 1,111 & 1 & 2 & 4 & 1 & 2 & 1 & 2 & 1 & 1 & 1 & 2 & & 2 & 2 \\
\hline 8 & 2 & 0.87 & 4 & \begin{tabular}{|l|}
1,111 \\
\end{tabular} & 2 & 2 & 1 & 1 & 3 & 1 & 2 & 2 & 2 & 2 & 1 & 1 & 2 & 2 \\
\hline 9 & 2 & 2 & 4 & \begin{tabular}{|l|}
1,111 \\
\end{tabular} & 1 & 1 & 3 & 1 & 3 & 1 & 2 & 2 & 1 & 1 & 1 & 4 & 1 & 2 \\
\hline 17 & 2 & 1.5 & 3 & 1,111 & 1 & 3 & 3 & 1 & 3 & 2 & 1 & 2 & 1 & 1 & 1 & 1 & 2 & 2 \\
\hline 18 & 2 & 2 & 4 & 1,111 & 1 & 2 & 1 & 1 & 3 & 1 & 2 & 2 & 2 & 2 & 1 & 1 & 2 & 2 \\
\hline 12 & 3 & 2.5 & 5 & \begin{tabular}{|l|}
1,111 \\
\end{tabular} & 1 & 3 & 1 & 2 & 3 & 1 & 2 & 2 & 1 & 1 & 1 & 2 & 2 & 2 \\
\hline 16 & 3 & 2.38 & 4 & 1,111 & 1 & 1 & 3 & 1 & 3 & 1 & 1 & 2 & 1 & 1 & 1 & 1 & 3 & 2 \\
\hline 10 & 3 & 1.6 & 3 & 1,333 & 1 & 1 & 1 & 1 & 3 & 2 & 2 & 1 & 2 & 2 & 1 & 4 & 2 & 2 \\
\hline 11 & 3.5 & 2.5 & 5 & 1,111 & 1 & 1 & 1 & 1 & 3 & 3 & 2 & 2 & 2 & 2 & 3 & 4 & 2 & 2 \\
\hline 6 & 4.5 & 1.3 & 3 & \begin{tabular}{|l|}
1,111 \\
\end{tabular} & 1 & 3 & 1 & 1 & 2 & 1 & 1 & 2 & 1 & 1 & 1 & 3 & 2 & 2 \\
\hline 13 & 5 & 1 & 2 & 1,600 & 2 & 1 & 3 & 1 & 2 & 1 & 2 & 2 & 1 & 1 & 1 & 2 & 3 & 2 \\
\hline 3 & 5 & 2.3 & 4 & 1,329 & 1 & 3 & 1 & 1 & 3 & 3 & 2 & 1 & 2 & 2 & 1 & 2 & 3 & 1 \\
\hline 14 & 6.5 & 0.67 & 2 & 1,111 & 1 & 2 & 6 & 1 & 3 & 1 & & & & & 1 & & 2 & 1 \\
\hline 4 & 8 & 0.25 & 2 & 2,500 & 1 & 1 & 1 & 1 & 1 & 3 & 1 & 1 & 1 & 1 & 2 & & 2 & 1 \\
\hline 5 & 8 & 0.2 & 2 & \begin{tabular}{|l|}
1,111 \\
\end{tabular} & 1 & 1 & 1 & 1 & 3 & 3 & & & & & 2 & 1 & 2 & 2 \\
\hline 7 & 8 & 0.13 & 1 & 1,111 & 1 & 1 & 1 & 1 & 3 & 3 & 2 & 2 & 1 & 1 & 3 & 3 & 1 & 2 \\
\hline 15 & 8 & 0.13 & 1 & \begin{tabular}{|l|}
1,111 \\
\end{tabular} & 1 & 1 & 2 & 1 & & 3 & 2 & 2 & 2 & 2 & 2 & & 2 & 2 \\
\hline
\end{tabular}


Legend for numerically coded stand characteristic and silvicultural practices data

\begin{tabular}{|c|c|c|c|c|}
\hline \multicolumn{5}{|c|}{ KEY } \\
\hline & 1 & 2 & 3 & 4 \\
\hline \multicolumn{5}{|l|}{ Stand Age } \\
\hline \multicolumn{5}{|l|}{ Stand Area } \\
\hline \multicolumn{5}{|l|}{ TPH } \\
\hline Land Ownership & $\begin{array}{l}\text { the land } \\
\text { owner is the } \\
\text { stand owner }\end{array}$ & $\begin{array}{c}\text { the land } \\
\text { owner is an } \\
\text { immediate } \\
\text { family } \\
\text { member }\end{array}$ & N/A & $\mathrm{N} / \mathrm{A}$ \\
\hline Stand Management & $\begin{array}{l}\text { the stand } \\
\text { owner } \\
\text { manages the } \\
\text { stand }\end{array}$ & $\begin{array}{l}\text { a forestry } \\
\text { extension } \\
\text { agent } \\
\text { manages the } \\
\text { stand for the } \\
\text { first year(s) }\end{array}$ & $\begin{array}{c}\text { someone } \\
\text { other than } \\
\text { the stand } \\
\text { owner or a } \\
\text { forestry } \\
\text { extension } \\
\text { agent } \\
\text { manages the } \\
\text { stand } \\
\end{array}$ & $\mathrm{N} / \mathrm{A}$ \\
\hline \multicolumn{5}{|l|}{ \# of stands } \\
\hline Seedling Origin & $\begin{array}{l}\text { seedlings } \\
\text { came from a } \\
\text { nursery } \\
\text { managed by } \\
\text { a forestry } \\
\text { extension } \\
\text { agent }\end{array}$ & $\begin{array}{l}\text { seedlings } \\
\text { came from a } \\
\text { family tree } \\
\text { nursery }\end{array}$ & N/A & $\mathrm{N} / \mathrm{A}$ \\
\hline Season of planting & fall & winter & spring & $\mathrm{N} / \mathrm{A}$ \\
\hline Replanting & $\begin{array}{c}\text { unestablished } \\
\text { trees were } \\
\text { replanted } \\
\text { within } 3 \\
\text { weeks } \\
\end{array}$ & $\begin{array}{c}\text { unestablished } \\
\text { trees were } \\
\text { replanted } \\
\text { within } 3 \\
\text { months } \\
\end{array}$ & $\begin{array}{l}\text { replanting } \\
\text { did not } \\
\text { occure }\end{array}$ & $\mathrm{N} / \mathrm{A}$ \\
\hline Chemical Fertilizer Use & $\begin{array}{c}\text { chemical } \\
\text { fertilizer was } \\
\text { used }\end{array}$ & $\begin{array}{c}\text { chemical } \\
\text { fertilizer was } \\
\text { not used }\end{array}$ & N/A & $\mathrm{N} / \mathrm{A}$ \\
\hline Natural Fertilizer Use & $\begin{array}{c}\text { natural } \\
\text { fertilizer was } \\
\text { used } \\
\end{array}$ & $\begin{array}{c}\text { natural } \\
\text { fertilizer was } \\
\text { not used }\end{array}$ & N/A & $\mathrm{N} / \mathrm{A}$ \\
\hline Pesticide Use & $\begin{array}{l}\text { chemical } \\
\text { pesticides } \\
\text { were used }\end{array}$ & $\begin{array}{c}\text { chemical } \\
\text { pesticides } \\
\text { were not } \\
\text { used }\end{array}$ & N/A & $\mathrm{N} / \mathrm{A}$ \\
\hline Land Preparation & $\begin{array}{l}\text { by tractor on } \\
\text { entire stand }\end{array}$ & $\begin{array}{c}\text { by shovel at } \\
\text { exact tree } \\
\text { planting } \\
\text { locations }\end{array}$ & $\begin{array}{c}\text { by oxen in } \\
\text { rows }\end{array}$ & $\mathrm{N} / \mathrm{A}$ \\
\hline Cleaning Practice & $\begin{array}{l}\text { chemicals } \\
\text { used for } \\
\text { cleaning }\end{array}$ & $\begin{array}{l}\text { chemicals } \\
\text { were not } \\
\text { used for } \\
\text { cleaning }\end{array}$ & N/A & $\mathrm{N} / \mathrm{A}$ \\
\hline Soil Type & yvy pyta & yvy moroti & yvy hu & yvy rosada \\
\hline Topographic position & depressed & flat ground & inclined & $\mathrm{N} / \mathrm{A}$ \\
\hline Thinned & $\begin{array}{l}\text { Stand was } \\
\text { thinned }\end{array}$ & $\begin{array}{c}\text { Stand has } \\
\text { not been } \\
\text { thinned }\end{array}$ & N/A & $\mathrm{N} / \mathrm{A}$ \\
\hline
\end{tabular}




\section{Appendix B}

\section{Individual Tree Data}

Tree volumes were calculated from Meskimen's (1978) volume equation for E. grandis. $\quad V=D^{2}(0.001818 H+0.0136)$

\begin{tabular}{ccccccc|}
$\begin{array}{c}\text { Stand } \\
\text { Age }\end{array}$ & Stand\# & Plot\# & Tree\# & $\begin{array}{c}\text { DBH } \\
(\mathrm{cm})\end{array}$ & $\begin{array}{c}\text { Total } \\
\text { Height } \\
(\mathrm{m})\end{array}$ & $\begin{array}{c}\text { Tree Volume } \\
(\mathrm{M} 3)\end{array}$ \\
\hline \hline & & & & & & \\
0.8 & 1 & 1 & 1 & 5 & 4 & 0.004413036 \\
0.8 & 1 & 1 & 2 & 5 & 4 & 0.004413036 \\
0.8 & 1 & 1 & 3 & 1 & 2 & 0.000124164 \\
0.8 & 1 & 1 & 4 & 3 & 3 & 0.001353083 \\
0.8 & 1 & 1 & 5 & 5 & 5 & 0.005067507 \\
0.8 & 1 & 1 & 6 & 4 & 4 & 0.002824343 \\
0.8 & 1 & 1 & 7 & 4 & 4 & 0.002824343 \\
0.8 & 1 & 1 & 8 & 3 & 4 & 0.001588693 \\
0.8 & 1 & 1 & 9 & 4 & 5 & 0.003243205 \\
0.8 & 1 & 2 & 1 & 4 & 5 & 0.003243205 \\
0.8 & 1 & 2 & 2 & 4 & 4 & 0.002824343 \\
0.8 & 1 & 2 & 3 & 5 & 5 & 0.005067507 \\
0.8 & 1 & 2 & 4 & 5 & 6 & 0.005721979 \\
0.8 & 1 & 2 & 5 & 5 & 6 & 0.005721979 \\
0.8 & 1 & 2 & 6 & 2 & 3 & 0.000601370 \\
0.8 & 1 & 2 & 7 & 5 & 5 & 0.005067507 \\
0.8 & 1 & 2 & 8 & 5 & 6 & 0.005721979 \\
0.8 & 1 & 2 & 9 & 5 & 5 & 0.005067507 \\
2 & 2 & 1 & 1 & 10 & 13 & 0.041213123 \\
2 & 2 & 1 & 2 & 7 & 12 & 0.018911666 \\
2 & 2 & 1 & 3 & 11 & 13 & 0.049867879 \\
2 & 2 & 1 & 4 & 14 & 12 & 0.075646664 \\
2 & 2 & 1 & 5 & 9 & 13 & 0.033382630 \\
2 & 2 & 1 & 6 & 10 & 13 & 0.041213123 \\
2 & 2 & 1 & 7 & 10 & 13 & 0.041213123 \\
2 & 2 & 1 & 8 & 10 & 13 & 0.041213123 \\
2 & 2 & 1 & 9 & 12 & 12 & 0.055577141 \\
2 & 2 & 1 & 10 & 7 & 10 & 0.016346137 \\
2 & 2 & 1 & 11 & 11 & 12 & 0.046700236 \\
2 & 2 & 1 & 12 & 8 & 11 & 0.023025504 \\
2 & 2 & 1 & 13 & 12 & 12 & 0.055577141 \\
2 & 2 & 1 & 14 & 14 & 13 & 0.080777721 \\
2 & 2 & 1 & 15 & 8 & 8 & 0.017999161 \\
2 & 2 & 1 & 16 & 10 & 12 & 0.038595236 \\
2 & 2 & 2 & 1 & 12 & 13 & 0.059346897 \\
2 & 2 & 2 & 2 & 12 & 13 & 0.059346897 \\
2 & 2 & 2 & 3 & 12 & 13 & 0.059346897
\end{tabular}




\begin{tabular}{|c|c|c|c|c|c|c|}
\hline 2 & 2 & 2 & 4 & 13 & 13 & 0.069650178 \\
\hline 2 & 2 & 2 & 5 & 11 & 13 & 0.049867879 \\
\hline 2 & 2 & 2 & 6 & 9 & 12 & 0.031262142 \\
\hline 2 & 2 & 2 & 7 & 11 & 13 & 0.049867879 \\
\hline 2 & 2 & 2 & 8 & 10 & 12 & 0.038595236 \\
\hline 2 & 2 & 2 & 9 & 12 & 13 & 0.059346897 \\
\hline 2 & 2 & 2 & 10 & 12 & 13 & 0.059346897 \\
\hline 2 & 2 & 2 & 11 & 11 & 13 & 0.049867879 \\
\hline 2 & 2 & 2 & 12 & 11 & 13 & 0.049867879 \\
\hline 5 & 3 & 1 & 1 & 16 & 18 & 0.139014545 \\
\hline 5 & 3 & 1 & 2 & 15 & 18 & 0.122180752 \\
\hline 5 & 3 & 1 & 3 & 20 & 20 & 0.238153320 \\
\hline 5 & 3 & 1 & 4 & 22 & 21 & 0.300836089 \\
\hline 5 & 3 & 1 & 5 & 23 & 19 & 0.301109145 \\
\hline 5 & 3 & 1 & 6 & 17 & 19 & 0.164500081 \\
\hline 5 & 3 & 2 & 1 & 21 & 19 & 0.251019155 \\
\hline 5 & 3 & 2 & 2 & 19 & 19 & 0.205482800 \\
\hline 5 & 3 & 2 & 3 & 20 & 20 & 0.238153320 \\
\hline 5 & 3 & 2 & 4 & 8 & 11 & 0.023025504 \\
\hline 5 & 3 & 3 & 1 & 19 & 19 & 0.205482800 \\
\hline 5 & 3 & 3 & 2 & 17 & 18 & 0.156934389 \\
\hline 5 & 3 & 3 & 3 & 9 & 13 & 0.033382630 \\
\hline 5 & 3 & 3 & 4 & 15 & 18 & 0.122180752 \\
\hline 5 & 3 & 3 & 5 & 9 & 15 & 0.037623606 \\
\hline 5 & 3 & 3 & 6 & 14 & 16 & 0.096170895 \\
\hline 5 & 3 & 4 & 1 & 16 & 18 & 0.139014545 \\
\hline 5 & 3 & 4 & 2 & 13 & 18 & 0.091771321 \\
\hline 5 & 3 & 4 & 3 & 17 & 20 & 0.172065774 \\
\hline 5 & 3 & 4 & 4 & 19 & 20 & 0.214933371 \\
\hline 5 & 3 & 4 & 5 & 18 & 19 & 0.184422236 \\
\hline 5 & 3 & 4 & 6 & 18 & 20 & 0.192904189 \\
\hline 8 & 4 & 1 & 1 & 19 & 24 & 0.252735655 \\
\hline 8 & 4 & 1 & 2 & 26 & 28 & 0.544054423 \\
\hline 8 & 4 & 1 & 3 & 18 & 23 & 0.218350048 \\
\hline 8 & 4 & 1 & 4 & 21 & 23 & 0.297198676 \\
\hline 8 & 4 & 1 & 5 & 14 & 21 & 0.121826185 \\
\hline 8 & 4 & 1 & 6 & 18 & 24 & 0.226832001 \\
\hline 8 & 4 & 1 & 7 & 15 & 14 & 0.098619772 \\
\hline 8 & 4 & 1 & 8 & 26 & 25 & 0.490963681 \\
\hline 8 & 4 & 1 & 9 & 16 & 24 & 0.179225284 \\
\hline 8 & 4 & 1 & 10 & 18 & 24 & 0.226832001 \\
\hline 8 & 4 & 1 & 11 & 26 & 25 & 0.490963681 \\
\hline 8 & 4 & 2 & 1 & 22 & 26 & 0.364188946 \\
\hline 8 & 4 & 2 & 2 & 21 & 27 & 0.343378197 \\
\hline 8 & 4 & 2 & 3 & 21 & 26 & 0.331833317 \\
\hline 8 & 4 & 2 & 4 & 25 & 27 & 0.486647105 \\
\hline 8 & 4 & 2 & 5 & 17 & 24 & 0.202328544 \\
\hline 8 & 5 & 1 & 1 & 12 & 15 & 0.066886411 \\
\hline
\end{tabular}




\begin{tabular}{|c|c|c|c|c|c|c|}
\hline 8 & 5 & 1 & 2 & 29 & 27 & 0.654832344 \\
\hline 8 & 5 & 1 & 3 & 30 & 27 & 0.700771831 \\
\hline 8 & 5 & 1 & 4 & 28 & 27 & 0.610450128 \\
\hline 8 & 5 & 1 & 5 & 27 & 24 & 0.510372001 \\
\hline 8 & 5 & 1 & 6 & 32 & 27 & 0.797322617 \\
\hline 8 & 5 & 2 & 1 & 32 & 27 & 0.797322617 \\
\hline 8 & 5 & 2 & 2 & 33 & 27 & 0.847933916 \\
\hline 8 & 5 & 2 & 3 & 33 & 24 & 0.762407558 \\
\hline 4.5 & 6 & 1 & 1 & 5 & 5 & 0.005067507 \\
\hline 4.5 & 6 & 1 & 2 & 9 & 11 & 0.029141653 \\
\hline 4.5 & 6 & 1 & 3 & 5 & 5 & 0.005067507 \\
\hline 4.5 & 6 & 1 & 4 & 9 & 10 & 0.027021165 \\
\hline 4.5 & 6 & 1 & 5 & 3 & 3 & 0.001353083 \\
\hline 4.5 & 6 & 1 & 6 & 8 & 8 & 0.017999161 \\
\hline 4.5 & 6 & 1 & 7 & 8 & 11 & 0.023025504 \\
\hline 4.5 & 6 & 1 & 8 & 11 & 11 & 0.043532593 \\
\hline 4.5 & 6 & 1 & 9 & 4 & 4 & 0.002824343 \\
\hline 4.5 & 6 & 1 & 10 & 9 & 9 & 0.024900677 \\
\hline 4.5 & 6 & 1 & 11 & 7 & 9 & 0.015063372 \\
\hline 4.5 & 6 & 1 & 12 & 5 & 7 & 0.006376451 \\
\hline 4.5 & 6 & 2 & 1 & 9 & 8 & 0.022780189 \\
\hline 4.5 & 6 & 2 & 2 & 9 & 12 & 0.031262142 \\
\hline 4.5 & 6 & 2 & 3 & 9 & 10 & 0.027021165 \\
\hline 4.5 & 6 & 2 & 4 & 15 & 13 & 0.092729527 \\
\hline 4.5 & 6 & 2 & 5 & 10 & 11 & 0.035977350 \\
\hline 4.5 & 6 & 2 & 6 & 13 & 13 & 0.069650178 \\
\hline 4.5 & 6 & 2 & 7 & 16 & 15 & 0.118909175 \\
\hline 4.5 & 6 & 2 & 8 & 17 & 16 & 0.141803004 \\
\hline 4.5 & 6 & 2 & 9 & 7 & 10 & 0.016346137 \\
\hline 4.5 & 6 & 3 & 1 & 9 & 11 & 0.029141653 \\
\hline 4.5 & 6 & 3 & 2 & 20 & 19 & 0.227681773 \\
\hline 4.5 & 6 & 3 & 3 & 20 & 19 & 0.227681773 \\
\hline 4.5 & 6 & 3 & 4 & 18 & 19 & 0.184422236 \\
\hline 4.5 & 6 & 3 & 5 & 19 & 19 & 0.205482800 \\
\hline 4.5 & 6 & 3 & 6 & 17 & 19 & 0.164500081 \\
\hline 4.5 & 6 & 3 & 7 & 20 & 19 & 0.227681773 \\
\hline 8 & 7 & 1 & 1 & 32 & 25 & 0.743708297 \\
\hline 8 & 7 & 1 & 2 & 38 & 18 & 0.784128917 \\
\hline 8 & 7 & 1 & 3 & 32 & 27 & 0.797322617 \\
\hline 8 & 7 & 1 & 4 & 43 & 25 & 1.342887345 \\
\hline 8 & 7 & 1 & 5 & 47 & 24 & 1.546518177 \\
\hline 8 & 7 & 1 & 6 & 37 & 27 & 1.065951819 \\
\hline 8 & 7 & 1 & 7 & 35 & 28 & 0.985897437 \\
\hline 8 & 7 & 1 & 8 & 27 & 27 & 0.567625183 \\
\hline 2 & 8 & 1 & 1 & 12 & 13 & 0.059346897 \\
\hline 2 & 8 & 1 & 2 & 9 & 11 & 0.029141653 \\
\hline 2 & 8 & 1 & 3 & 10 & 11 & 0.035977350 \\
\hline 2 & 8 & 1 & 4 & 11 & 13 & 0.049867879 \\
\hline
\end{tabular}




\begin{tabular}{|c|c|c|c|c|c|c|}
\hline 2 & 8 & 1 & 5 & 6 & 8 & 0.010124528 \\
\hline 2 & 8 & 1 & 6 & 11 & 12 & 0.046700236 \\
\hline 2 & 8 & 1 & 7 & 11 & 12 & 0.046700236 \\
\hline 2 & 8 & 1 & 8 & 10 & 12 & 0.038595236 \\
\hline 2 & 8 & 1 & 9 & 11 & 12 & 0.046700236 \\
\hline 2 & 8 & 2 & 1 & 8 & 11 & 0.023025504 \\
\hline 2 & 8 & 2 & 2 & 7 & 9 & 0.015063372 \\
\hline 2 & 8 & 2 & 3 & 8 & 10 & 0.021350056 \\
\hline 2 & 8 & 2 & 4 & 10 & 12 & 0.038595236 \\
\hline 2 & 8 & 2 & 5 & 12 & 12 & 0.055577141 \\
\hline 2 & 8 & 2 & 6 & 11 & 12 & 0.046700236 \\
\hline 2 & 8 & 2 & 7 & 9 & 11 & 0.029141653 \\
\hline 2 & 8 & 2 & 8 & 8 & 10 & 0.021350056 \\
\hline 2 & 8 & 3 & 1 & 7 & 8 & 0.013780608 \\
\hline 2 & 8 & 3 & 2 & 7 & 8 & 0.013780608 \\
\hline 2 & 8 & 3 & 3 & 10 & 9 & 0.030741576 \\
\hline 2 & 8 & 3 & 4 & 6 & 9 & 0.011066968 \\
\hline 2 & 8 & 3 & 5 & 10 & 11 & 0.035977350 \\
\hline 2 & 8 & 3 & 6 & 6 & 8 & 0.010124528 \\
\hline 2 & 8 & 3 & 7 & 9 & 9 & 0.024900677 \\
\hline 2 & 8 & 3 & 8 & 6 & 8 & 0.010124528 \\
\hline 2 & 8 & 3 & 9 & 10 & 10 & 0.033359463 \\
\hline 2 & 8 & 3 & 10 & 1 & 2 & 0.000124164 \\
\hline 2 & 8 & 3 & 11 & 9 & 9 & 0.024900677 \\
\hline 2 & 8 & 3 & 12 & 10 & 9 & 0.030741576 \\
\hline 2 & 8 & 4 & 1 & 13 & 12 & 0.065225950 \\
\hline 2 & 8 & 4 & 2 & 8 & 12 & 0.024700951 \\
\hline 2 & 8 & 4 & 3 & 10 & 11 & 0.035977350 \\
\hline 2 & 8 & 4 & 4 & 10 & 13 & 0.041213123 \\
\hline 2 & 8 & 4 & 5 & 10 & 12 & 0.038595236 \\
\hline 2 & 8 & 4 & 6 & 9 & 11 & 0.029141653 \\
\hline 2 & 8 & 4 & 7 & 10 & 13 & 0.041213123 \\
\hline 2 & 8 & 4 & 8 & 12 & 12 & 0.055577141 \\
\hline 2 & 8 & 4 & 9 & 10 & 12 & 0.038595236 \\
\hline 2 & 9 & 1 & 1 & 8 & 9 & 0.019674609 \\
\hline 2 & 9 & 1 & 2 & 8 & 9 & 0.019674609 \\
\hline 2 & 9 & 1 & 3 & 6 & 8 & 0.010124528 \\
\hline 2 & 9 & 1 & 4 & 10 & 9 & 0.030741576 \\
\hline 2 & 9 & 1 & 5 & 8 & 10 & 0.021350056 \\
\hline 2 & 9 & 1 & 6 & 5 & 7 & 0.006376451 \\
\hline 2 & 9 & 1 & 7 & 5 & 6 & 0.005721979 \\
\hline 2 & 9 & 1 & 8 & 9 & 9 & 0.024900677 \\
\hline 2 & 9 & 1 & 9 & 9 & 10 & 0.027021165 \\
\hline 2 & 9 & 1 & 10 & 9 & 10 & 0.027021165 \\
\hline 2 & 9 & 1 & 11 & 11 & 11 & 0.043532593 \\
\hline 2 & 9 & 1 & 12 & 9 & 10 & 0.027021165 \\
\hline 2 & 9 & 1 & 13 & 13 & 12 & 0.065225950 \\
\hline 2 & 9 & 1 & 14 & 3 & 4 & 0.001588693 \\
\hline
\end{tabular}




\begin{tabular}{|c|c|c|c|c|c|c|}
\hline 2 & 9 & 2 & 1 & 5 & 6 & 0.005721979 \\
\hline 2 & 9 & 2 & 2 & 9 & 11 & 0.029141653 \\
\hline 2 & 9 & 2 & 3 & 8 & 9 & 0.019674609 \\
\hline 2 & 9 & 2 & 4 & 7 & 9 & 0.015063372 \\
\hline 2 & 9 & 2 & 5 & 8 & 8 & 0.017999161 \\
\hline 2 & 9 & 2 & 6 & 9 & 10 & 0.027021165 \\
\hline 2 & 9 & 2 & 7 & 9 & 11 & 0.029141653 \\
\hline 2 & 9 & 2 & 8 & 11 & 12 & 0.046700236 \\
\hline 2 & 9 & 3 & 1 & 7 & 9 & 0.015063372 \\
\hline 2 & 9 & 3 & 2 & 3 & 3 & 0.001353083 \\
\hline 2 & 9 & 3 & 3 & 4 & 3 & 0.002405481 \\
\hline 2 & 9 & 3 & 4 & 5 & 4 & 0.004413036 \\
\hline 2 & 9 & 3 & 5 & 5 & 4 & 0.004413036 \\
\hline 2 & 9 & 3 & 6 & 8 & 6 & 0.014648266 \\
\hline 2 & 9 & 3 & 7 & 4 & 3 & 0.002405481 \\
\hline 2 & 9 & 3 & 8 & 3 & 3 & 0.001353083 \\
\hline 2 & 9 & 3 & 9 & 3 & 4 & 0.001588693 \\
\hline 2 & 9 & 3 & 10 & 4 & 8 & 0.004499790 \\
\hline 2 & 9 & 4 & 1 & 4 & 4 & 0.002824343 \\
\hline 2 & 9 & 4 & 2 & 7 & 8 & 0.013780608 \\
\hline 2 & 9 & 4 & 3 & 5 & 6 & 0.005721979 \\
\hline 2 & 9 & 4 & 4 & 7 & 7 & 0.012497844 \\
\hline 2 & 9 & 4 & 5 & 9 & 8 & 0.022780189 \\
\hline 2 & 9 & 4 & 6 & 5 & 5 & 0.005067507 \\
\hline 2 & 9 & 4 & 7 & 4 & 5 & 0.003243205 \\
\hline 3 & 10 & 1 & 1 & 15 & 15 & 0.104510017 \\
\hline 3 & 10 & 1 & 2 & 7 & 10 & 0.016346137 \\
\hline 3 & 10 & 1 & 3 & 13 & 15 & 0.078498635 \\
\hline 3 & 10 & 1 & 4 & 7 & 7 & 0.012497844 \\
\hline 3 & 10 & 1 & 5 & 9 & 10 & 0.027021165 \\
\hline 3 & 10 & 1 & 6 & 13 & 13 & 0.069650178 \\
\hline 3 & 10 & 1 & 7 & 5 & 7 & 0.006376451 \\
\hline 3 & 10 & 1 & 8 & 7 & 7 & 0.012497844 \\
\hline 3 & 10 & 1 & 9 & 5 & 6 & 0.005721979 \\
\hline 3 & 10 & 2 & 1 & 13 & 14 & 0.074074407 \\
\hline 3 & 10 & 2 & 2 & 11 & 14 & 0.053035522 \\
\hline 3 & 10 & 2 & 3 & 18 & 17 & 0.167458331 \\
\hline 3 & 10 & 2 & 4 & 12 & 14 & 0.063116654 \\
\hline 3 & 10 & 2 & 5 & 12 & 15 & 0.066886411 \\
\hline 3 & 10 & 2 & 6 & 13 & 14 & 0.074074407 \\
\hline 3 & 10 & 2 & 7 & 12 & 15 & 0.066886411 \\
\hline 3 & 10 & 2 & 8 & 6 & 10 & 0.012009407 \\
\hline 3 & 10 & 2 & 9 & 12 & 13 & 0.059346897 \\
\hline 3 & 10 & 2 & 10 & 14 & 14 & 0.085908779 \\
\hline 3 & 10 & 3 & 1 & 14 & 16 & 0.096170895 \\
\hline 3 & 10 & 3 & 2 & 16 & 17 & 0.132312755 \\
\hline 3 & 10 & 3 & 3 & 5 & 9 & 0.007685394 \\
\hline 3 & 10 & 3 & 4 & 10 & 14 & 0.043831010 \\
\hline
\end{tabular}




\begin{tabular}{|c|c|c|c|c|c|c|}
\hline 3 & 10 & 3 & 5 & 16 & 17 & 0.132312755 \\
\hline 3 & 10 & 3 & 6 & 9 & 13 & 0.033382630 \\
\hline 3 & 10 & 3 & 7 & 10 & 15 & 0.046448897 \\
\hline 3 & 10 & 3 & 8 & 13 & 17 & 0.087347092 \\
\hline 3.5 & 11 & 1 & 1 & 14 & 18 & 0.106433011 \\
\hline 3.5 & 11 & 1 & 2 & 16 & 16 & 0.125610965 \\
\hline 3.5 & 11 & 1 & 3 & 16 & 17 & 0.132312755 \\
\hline 3.5 & 11 & 1 & 4 & 16 & 19 & 0.145716335 \\
\hline 3.5 & 11 & 1 & 5 & 15 & 18 & 0.122180752 \\
\hline 3.5 & 11 & 1 & 6 & 1 & 18 & 0.000543026 \\
\hline 3.5 & 11 & 1 & 7 & 17 & 20 & 0.172065774 \\
\hline 3.5 & 11 & 1 & 8 & 14 & 18 & 0.106433011 \\
\hline 3.5 & 11 & 1 & 9 & 8 & 12 & 0.024700951 \\
\hline 3.5 & 11 & 1 & 10 & 26 & 20 & 0.402479111 \\
\hline 3.5 & 11 & 2 & 1 & 10 & 10 & 0.033359463 \\
\hline 3.5 & 11 & 2 & 2 & 18 & 18 & 0.175940283 \\
\hline 3.5 & 11 & 2 & 3 & 15 & 16 & 0.110400262 \\
\hline 3.5 & 11 & 2 & 4 & 12 & 14 & 0.063116654 \\
\hline 3.5 & 11 & 2 & 5 & 16 & 15 & 0.118909175 \\
\hline 3.5 & 11 & 2 & 6 & 15 & 16 & 0.110400262 \\
\hline 3.5 & 11 & 2 & 7 & 18 & 17 & 0.167458331 \\
\hline 3.5 & 11 & 2 & 8 & 18 & 16 & 0.158976378 \\
\hline 3.5 & 11 & 2 & 9 & 7 & 11 & 0.017628901 \\
\hline 3.5 & 11 & 2 & 10 & 5 & 11 & 0.008994337 \\
\hline 3.5 & 11 & 3 & 1 & 6 & 8 & 0.010124528 \\
\hline 3.5 & 11 & 3 & 2 & 20 & 16 & 0.196267133 \\
\hline 3.5 & 11 & 3 & 3 & 17 & 16 & 0.141803004 \\
\hline 3.5 & 11 & 3 & 4 & 10 & 13 & 0.041213123 \\
\hline 3.5 & 11 & 3 & 5 & 5 & 8 & 0.007030922 \\
\hline 3.5 & 11 & 3 & 6 & 16 & 15 & 0.118909175 \\
\hline 3.5 & 11 & 3 & 7 & 5 & 7 & 0.006376451 \\
\hline 3.5 & 11 & 3 & 8 & 19 & 16 & 0.177131087 \\
\hline 3.5 & 11 & 3 & 9 & 7 & 8 & 0.013780608 \\
\hline 3.5 & 11 & 3 & 10 & 5 & 5 & 0.005067507 \\
\hline 3.5 & 11 & 3 & 11 & 8 & 11 & 0.023025504 \\
\hline 3.5 & 11 & 4 & 1 & 15 & 14 & 0.098619772 \\
\hline 3.5 & 11 & 4 & 2 & 5 & 7 & 0.006376451 \\
\hline 3.5 & 11 & 4 & 3 & 19 & 15 & 0.167680517 \\
\hline 3.5 & 11 & 4 & 4 & 15 & 15 & 0.104510017 \\
\hline 3.5 & 11 & 4 & 5 & 5 & 7 & 0.006376451 \\
\hline 3.5 & 11 & 4 & 6 & 17 & 14 & 0.126671619 \\
\hline 3.5 & 11 & 4 & 7 & 7 & 8 & 0.013780608 \\
\hline 3.5 & 11 & 4 & 8 & 8 & 8 & 0.017999161 \\
\hline 3.5 & 11 & 4 & 9 & 7 & 7 & 0.012497844 \\
\hline 3.5 & 11 & 4 & 10 & 9 & 8 & 0.022780189 \\
\hline 3.5 & 11 & 5 & 1 & 18 & 21 & 0.201386142 \\
\hline 3.5 & 11 & 5 & 2 & 16 & 18 & 0.139014545 \\
\hline 3.5 & 11 & 5 & 3 & 14 & 17 & 0.101301953 \\
\hline
\end{tabular}




\begin{tabular}{|c|c|c|c|c|c|c|}
\hline 3.5 & 11 & 5 & 4 & 15 & 18 & 0.122180752 \\
\hline 3.5 & 11 & 5 & 5 & 5 & 7 & 0.006376451 \\
\hline 3.5 & 11 & 5 & 6 & 19 & 18 & 0.196032229 \\
\hline 3.5 & 11 & 5 & 7 & 18 & 17 & 0.167458331 \\
\hline 3 & 12 & 1 & 1 & 5 & 8 & 0.007030922 \\
\hline 3 & 12 & 1 & 2 & 14 & 13 & 0.080777721 \\
\hline 3 & 12 & 1 & 3 & 10 & 10 & 0.033359463 \\
\hline 3 & 12 & 1 & 4 & 6 & 8 & 0.010124528 \\
\hline 3 & 12 & 1 & 5 & 5 & 6 & 0.005721979 \\
\hline 3 & 12 & 1 & 6 & 15 & 11 & 0.080949037 \\
\hline 3 & 12 & 2 & 1 & 8 & 7 & 0.016323714 \\
\hline 3 & 12 & 2 & 2 & 5 & 7 & 0.006376451 \\
\hline 3 & 12 & 2 & 3 & 6 & 7 & 0.009182089 \\
\hline 3 & 12 & 2 & 4 & 9 & 7 & 0.020659700 \\
\hline 3 & 12 & 2 & 5 & 15 & 13 & 0.092729527 \\
\hline 3 & 12 & 3 & 1 & 10 & 10 & 0.033359463 \\
\hline 3 & 12 & 3 & 2 & 11 & 10 & 0.040364950 \\
\hline 3 & 12 & 3 & 3 & 14 & 13 & 0.080777721 \\
\hline 3 & 12 & 3 & 4 & 9 & 9 & 0.024900677 \\
\hline 3 & 12 & 3 & 5 & 9 & 9 & 0.024900677 \\
\hline 3 & 12 & 3 & 6 & 2 & 4 & 0.000706086 \\
\hline 3 & 12 & 3 & 7 & 4 & 4 & 0.002824343 \\
\hline 3 & 12 & 4 & 1 & 10 & 9 & 0.030741576 \\
\hline 3 & 12 & 4 & 2 & 11 & 11 & 0.043532593 \\
\hline 3 & 12 & 4 & 3 & 10 & 11 & 0.035977350 \\
\hline 3 & 12 & 4 & 4 & 8 & 8 & 0.017999161 \\
\hline 3 & 12 & 4 & 5 & 14 & 14 & 0.085908779 \\
\hline 3 & 12 & 4 & 6 & 12 & 11 & 0.051807384 \\
\hline 3 & 12 & 5 & 1 & 15 & 11 & 0.080949037 \\
\hline 3 & 12 & 5 & 2 & 12 & 13 & 0.059346897 \\
\hline 3 & 12 & 5 & 3 & 7 & 9 & 0.015063372 \\
\hline 3 & 12 & 5 & 4 & 17 & 13 & 0.119105926 \\
\hline 3 & 12 & 5 & 5 & 9 & 9 & 0.024900677 \\
\hline 3 & 12 & 5 & 6 & 6 & 8 & 0.010124528 \\
\hline 3 & 12 & 5 & 7 & 9 & 10 & 0.027021165 \\
\hline 5 & 13 & 1 & 1 & 12 & 18 & 0.078195682 \\
\hline 5 & 13 & 1 & 2 & 18 & 21 & 0.201386142 \\
\hline 5 & 13 & 1 & 3 & 19 & 20 & 0.214933371 \\
\hline 5 & 13 & 1 & 4 & 5 & 8 & 0.007030922 \\
\hline 5 & 13 & 1 & 5 & 16 & 20 & 0.152418125 \\
\hline 5 & 13 & 1 & 6 & 11 & 17 & 0.062538451 \\
\hline 5 & 13 & 1 & 7 & 8 & 12 & 0.024700951 \\
\hline 5 & 13 & 1 & 8 & 17 & 19 & 0.164500081 \\
\hline 5 & 13 & 1 & 9 & 18 & 19 & 0.184422236 \\
\hline 5 & 13 & 1 & 10 & 9 & 10 & 0.027021165 \\
\hline 5 & 13 & 1 & 11 & 16 & 17 & 0.132312755 \\
\hline 5 & 13 & 1 & 12 & 6 & 13 & 0.014836724 \\
\hline 5 & 13 & 1 & 13 & 7 & 12 & 0.018911666 \\
\hline
\end{tabular}




\begin{tabular}{|c|c|c|c|c|c|c|}
\hline 5 & 13 & 2 & 1 & 14 & 15 & 0.091039837 \\
\hline 5 & 13 & 2 & 2 & 18 & 17 & 0.167458331 \\
\hline 5 & 13 & 2 & 3 & 4 & 11 & 0.005756376 \\
\hline 5 & 13 & 2 & 4 & 15 & 15 & 0.104510017 \\
\hline 5 & 13 & 2 & 5 & 17 & 19 & 0.164500081 \\
\hline 5 & 13 & 2 & 6 & 9 & 12 & 0.031262142 \\
\hline 5 & 13 & 2 & 7 & 10 & 13 & 0.041213123 \\
\hline 5 & 13 & 2 & 8 & 8 & 10 & 0.021350056 \\
\hline 5 & 13 & 2 & 9 & 11 & 13 & 0.049867879 \\
\hline 5 & 13 & 2 & 10 & 6 & 7 & 0.009182089 \\
\hline 5 & 13 & 2 & 11 & 18 & 17 & 0.167458331 \\
\hline 5 & 13 & 2 & 12 & 6 & 10 & 0.012009407 \\
\hline 5 & 13 & 2 & 13 & 16 & 17 & 0.132312755 \\
\hline 6.5 & 14 & 1 & 1 & 29 & 27 & 0.654832344 \\
\hline 6.5 & 14 & 1 & 2 & 20 & 26 & 0.300982600 \\
\hline 6.5 & 14 & 1 & 3 & 24 & 26 & 0.433414945 \\
\hline 6.5 & 14 & 1 & 4 & 20 & 24 & 0.280039507 \\
\hline 6.5 & 14 & 1 & 5 & 23 & 27 & 0.411898110 \\
\hline 6.5 & 14 & 2 & 1 & 20 & 22 & 0.259096413 \\
\hline 6.5 & 14 & 2 & 2 & 22 & 25 & 0.351518375 \\
\hline 6.5 & 14 & 2 & 3 & 23 & 23 & 0.356503627 \\
\hline 6.5 & 14 & 2 & 4 & 21 & 19 & 0.251019155 \\
\hline 8 & 15 & 1 & 1 & 20 & 20 & 0.238153320 \\
\hline 8 & 15 & 1 & 2 & 39 & 25 & 1.104668281 \\
\hline 8 & 15 & 1 & 3 & 34 & 25 & 0.839576945 \\
\hline 8 & 15 & 1 & 4 & 30 & 24 & 0.630088891 \\
\hline 8 & 15 & 1 & 5 & 31 & 24 & 0.672794915 \\
\hline 3 & 16 & 1 & 1 & 12 & 14 & 0.063116654 \\
\hline 3 & 16 & 1 & 2 & 11 & 13 & 0.049867879 \\
\hline 3 & 16 & 1 & 3 & 3 & 4 & 0.001588693 \\
\hline 3 & 16 & 1 & 4 & 15 & 15 & 0.104510017 \\
\hline 3 & 16 & 1 & 5 & 5 & 7 & 0.006376451 \\
\hline 3 & 16 & 1 & 6 & 13 & 14 & 0.074074407 \\
\hline 3 & 16 & 1 & 7 & 12 & 13 & 0.059346897 \\
\hline 3 & 16 & 1 & 8 & 9 & 11 & 0.029141653 \\
\hline 3 & 16 & 1 & 9 & 1 & 2 & 0.000124164 \\
\hline 3 & 16 & 2 & 1 & 14 & 13 & 0.080777721 \\
\hline 3 & 16 & 2 & 2 & 6 & 8 & 0.010124528 \\
\hline 3 & 16 & 2 & 3 & 13 & 14 & 0.074074407 \\
\hline 3 & 16 & 2 & 4 & 13 & 12 & 0.065225950 \\
\hline 3 & 16 & 2 & 5 & 3 & 5 & 0.001824303 \\
\hline 3 & 16 & 2 & 6 & 12 & 12 & 0.055577141 \\
\hline 3 & 16 & 2 & 7 & 11 & 11 & 0.043532593 \\
\hline 3 & 16 & 2 & 8 & 2 & 4 & 0.000706086 \\
\hline 3 & 16 & 2 & 9 & 13 & 14 & 0.074074407 \\
\hline 3 & 16 & 3 & 1 & 8 & 11 & 0.023025504 \\
\hline 3 & 16 & 3 & 2 & 13 & 14 & 0.074074407 \\
\hline 3 & 16 & 3 & 3 & 15 & 14 & 0.098619772 \\
\hline
\end{tabular}




\begin{tabular}{|c|c|c|c|c|c|c|}
\hline 3 & 16 & 3 & 4 & 12 & 13 & 0.059346897 \\
\hline 3 & 16 & 3 & 5 & 12 & 14 & 0.063116654 \\
\hline 3 & 16 & 3 & 6 & 14 & 14 & 0.085908779 \\
\hline 3 & 16 & 3 & 7 & 14 & 13 & 0.080777721 \\
\hline 3 & 16 & 3 & 8 & 12 & 11 & 0.051807384 \\
\hline 3 & 16 & 3 & 9 & 11 & 12 & 0.046700236 \\
\hline 3 & 16 & 4 & 1 & 5 & 4 & 0.004413036 \\
\hline 3 & 16 & 4 & 2 & 4 & 3 & 0.002405481 \\
\hline 3 & 16 & 4 & 3 & 3 & 4 & 0.001588693 \\
\hline 3 & 16 & 4 & 4 & 1 & 2 & 0.000124164 \\
\hline 3 & 16 & 4 & 5 & 4 & 4 & 0.002824343 \\
\hline 3 & 16 & 4 & 6 & 1 & 3 & 0.000150343 \\
\hline 3 & 16 & 4 & 7 & 8 & 8 & 0.017999161 \\
\hline 3 & 16 & 4 & 8 & 7 & 7 & 0.012497844 \\
\hline 2 & 17 & 1 & 1 & 11 & 12 & 0.046700236 \\
\hline 2 & 17 & 1 & 2 & 14 & 12 & 0.075646664 \\
\hline 2 & 17 & 1 & 3 & 10 & 11 & 0.035977350 \\
\hline 2 & 17 & 1 & 4 & 8 & 11 & 0.023025504 \\
\hline 2 & 17 & 1 & 5 & 13 & 11 & 0.060801721 \\
\hline 2 & 17 & 1 & 6 & 9 & 11 & 0.029141653 \\
\hline 2 & 17 & 1 & 7 & 12 & 11 & 0.051807384 \\
\hline 2 & 17 & 1 & 8 & 13 & 12 & 0.065225950 \\
\hline 2 & 17 & 2 & 1 & 13 & 16 & 0.082922864 \\
\hline 2 & 17 & 2 & 2 & 6 & 9 & 0.011066968 \\
\hline 2 & 17 & 2 & 3 & 6 & 9 & 0.011066968 \\
\hline 2 & 17 & 2 & 4 & 8 & 10 & 0.021350056 \\
\hline 2 & 17 & 2 & 5 & 10 & 11 & 0.035977350 \\
\hline 2 & 17 & 2 & 6 & 18 & 14 & 0.142012472 \\
\hline 2 & 17 & 2 & 7 & 4 & 8 & 0.004499790 \\
\hline 2 & 17 & 2 & 8 & 7 & 10 & 0.016346137 \\
\hline 2 & 17 & 3 & 1 & 9 & 9 & 0.024900677 \\
\hline 2 & 17 & 3 & 2 & 4 & 9 & 0.004918652 \\
\hline 2 & 17 & 3 & 3 & 7 & 6 & 0.011215079 \\
\hline 2 & 17 & 3 & 4 & 1 & 3 & 0.000150343 \\
\hline 2 & 17 & 3 & 5 & 1 & 3 & 0.000150343 \\
\hline 2 & 17 & 3 & 6 & 1 & 5 & 0.000202700 \\
\hline 2 & 17 & 3 & 7 & 1 & 5 & 0.000202700 \\
\hline 2 & 18 & 1 & 1 & 12 & 12 & 0.055577141 \\
\hline 2 & 18 & 1 & 2 & 12 & 12 & 0.055577141 \\
\hline 2 & 18 & 1 & 3 & 13 & 13 & 0.069650178 \\
\hline 2 & 18 & 1 & 4 & 11 & 12 & 0.046700236 \\
\hline 2 & 18 & 1 & 5 & 10 & 12 & 0.038595236 \\
\hline 2 & 18 & 1 & 6 & 9 & 11 & 0.029141653 \\
\hline 2 & 18 & 1 & 7 & 8 & 9 & 0.019674609 \\
\hline 2 & 18 & 1 & 8 & 9 & 12 & 0.031262142 \\
\hline 2 & 18 & 1 & 9 & 11 & 12 & 0.046700236 \\
\hline 2 & 18 & 1 & 10 & 11 & 13 & 0.049867879 \\
\hline 2 & 18 & 1 & 11 & 6 & 8 & 0.010124528 \\
\hline
\end{tabular}




\begin{tabular}{|lllcccc|}
2 & 18 & 1 & 12 & 13 & 13 & 0.069650178 \\
2 & 18 & 2 & 1 & 12 & 12 & 0.055577141 \\
2 & 18 & 2 & 2 & 8 & 8 & 0.017999161 \\
2 & 18 & 2 & 3 & 11 & 11 & 0.043532593 \\
2 & 18 & 2 & 4 & 9 & 12 & 0.031262142 \\
2 & 18 & 2 & 5 & 11 & 11 & 0.043532593 \\
2 & 18 & 2 & 6 & 6 & 9 & 0.011066968 \\
2 & 18 & 2 & 7 & 10 & 12 & 0.038595236 \\
2 & 18 & 2 & 8 & 13 & 12 & 0.065225950 \\
2 & 18 & 2 & 9 & 11 & 11 & 0.043532593 \\
2 & 18 & 3 & 1 & 13 & 13 & 0.069650178 \\
2 & 18 & 3 & 2 & 9 & 12 & 0.031262142 \\
2 & 18 & 3 & 3 & 12 & 13 & 0.059346897 \\
2 & 18 & 3 & 4 & 10 & 12 & 0.038595236 \\
2 & 18 & 3 & 5 & 14 & 12 & 0.075646664 \\
2 & 18 & 3 & 6 & 13 & 13 & 0.069650178 \\
2 & 18 & 3 & 7 & 1 & 3 & 0.000150343 \\
2 & 18 & 3 & 8 & 11 & 12 & 0.046700236 \\
2 & 18 & 3 & 9 & 12 & 13 & 0.059346897 \\
2 & 18 & 4 & 1 & 7 & 8 & 0.013780608 \\
2 & 18 & 4 & 2 & 12 & 11 & 0.051807384 \\
2 & 18 & 4 & 3 & 10 & 11 & 0.035977350 \\
2 & 18 & 4 & 4 & 12 & 11 & 0.051807384 \\
2 & 18 & 4 & 5 & 9 & 10 & 0.027021165 \\
2 & 18 & 4 & 6 & 12 & 11 & 0.051807384 \\
2 & 18 & 4 & 7 & 9 & 9 & 0.024900677 \\
2 & 18 & 4 & 8 & 10 & 12 & 0.038595236 \\
\hline & & & & & & \\
\hline
\end{tabular}

